\title{
THE WORLD OF TO-DAY
}

\section{REIGN EXCHANGE BEFORE, DURING, AND AFTER THE WAR}

BY

T. E. GREGORY, B.Sc. (Econ.), Lond.

Cassel Reader in Commerce, University of London

HUMPHREY MILFORD OXFORD UNIVERSITY PRESS

LONDON EDINBURGH GLASGOW COPENHAGEN NEW YORK TORONTO MELBOURNE CAPE TOWN BOMBAY CALCUTTA MADRAS SHANGHAI PEKING 


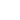




$$
\text { . }
$$




\section{FOREIGN EXCHANGE \\ BEFORE, DURING, AND AFTER THE WAR}




\section{THE WORLD OF TO-DAY}

Under the general editorship of

VICTOR GOLLANCZ.

Books of kindred interest to the present which are already published in this series include :

MIODERN FINANCE. By Emile Burns.

A CAPITAL LEVY AND A LEVY ON WAR WEALTH. By Prof. A. C. Pigou.

WHY PRICES RISE AND FALL. By F. W. Pethick Lawrence. 


\section{THE WORLD OF TO-DAY}

\section{FOREIGN EXCHANGE BEFORE, DURING, AND AFTER THE WAR}

BY

T. E. GREGORY, B.Sc. (Econ.), Lond. Cassel Reader in Commerce, University of London

\section{HUMPHREY MILFORD OXFORD UNIVERSITY PRESS} LONDON EDINBURGH GLASGOW COPENHAGEN NEW YORK TORONTO MELBOURNE CAPE TOWN BOMBAY CALCUTTA MADRAS SHANGHAI PEKING 1921 
TO

EDWIN CANNAN 


\section{CONTENTS}

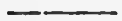

PAGE

(.hapter I. The Market and its Meaning $\quad \ldots \quad 9$

II. How to Read the Exchange Article 19

III. Exchange Fluctuations and the BalANCE OF INDEBTEDNESS... ... 31

IV. Pre-War Methods of Regulating THE Exchanges $\quad \ldots \quad \ldots \quad \ldots \quad \ldots 45$

V. The Foreign Exchanges During the

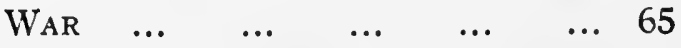

VI. The Present Position of the Foreign

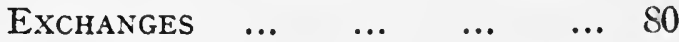

$\begin{array}{llllll}\text { VII. Remedies... } & \ldots & \ldots & \ldots & \ldots & 91\end{array}$

$\begin{array}{lllllllll}\text { BIBLIOGRAPHY } & \ldots & \ldots & \ldots & \ldots & \ldots & \ldots & 105\end{array}$

Appendix 1. Resolution No. XV. OF the BRUssels InTERnATIONAL ConFERENCE $\quad \ldots \quad \ldots \quad \ldots \quad \ldots 107$

Appendix 2. Exchange Statistics $\ldots$... 108 


\section{Digitized by the Internet Archive in 2007 with funding from Microsoft Corporation}




\section{PREFACE}

THIs little book does not in any way pretend to be an exhaustive treatment of the problems of foreign exchange. Let me hasten to add that it is not incomplete in the sense that it scamps what I believe to be the real matters of principle at issue. Exchange experts at the present time divide themselves into two camps: those who think that the exchanges are dislocated because of inflation, and those who think that they are dislocated because of "an excess of imports over exports." To the inexpert reader I have hoped to make clear the underlying principles; but I should be glad if, to my colleagues of the Universities, and the counting house also, my defence of the first of these schools of thought should prove of interest. Fortunately, there is less reason now to emphasise one's belief in this school than there once was. The view that the "Adverse Trade Balance" is an effect, and not a cause, which sounded so strange a little while ago, is being accepted fairly generally at the present moment, though not always, perhaps, very consciously.

\section{T. E. GREGORY.}

\section{The LONDON School of Economics}

\section{and Political Science,}

Clare Market, W.C.2.

January 24, 1921. 


\section{From Hansard, 21/12/20, col. I657:}

Lr.-Col. Hurst: “. . . . Of course this subject of foreign exchanges is one I know very little about, and I believe very few people do know anything about it. Indeed, I have read that only one person knows the real arcana of foreign exchanges, and he is in a lunatic asylum. The late Lord Goschen was thought to know something about it, but to the great mass of the people it is a very difficult subject indeed, and very humbly and tentatively I make the suggestion to my right hon. friend that it might be wise to appoint a small committee of experts, if any in this country, who do understand this question-

(Mr. J. Jones : "You do not want to send them to the asylum, do you?)-so that something may be done to adjust one of the rootcauses of the short-time and under-employment from which our country .... is suffering." 


\title{
FOREIGN EXCHANGE
}

\author{
BEFORE, DURING, AND \\ AFTER THE WAR
}

\section{CHAPTER I.}

The Market and its Meaning.

$\S 1$. Ours is a weary and disillusioned generation, dealing with a world which is nearer collapse than it has been at any time since the downfall of the Roman Empire. The problem which is discussed in this little book is an integral part of the general problem of reconstruction after the ravages of war. It will be shown in detail in the course of the subsequent chapters that the main cause of the dislocation of the exchanges has been the almost universal disregard of the rules of common sense in the treatment of the money supply of the world, or, as it is usually put, the dislocation of the exchanges is an inevitable effect of inflation. But this task of detailed explanation cannot be anticipated by mere repetition of phrases. It will suffice if we point to some of the difficulties of the moment, which arise directly from the dislocation of the exchanges.

A wool merchant with whom I talked a few days ago pointed out to me that at present it was a profitable policy to re-import from Constantinople woollen goods which had been sent out there shortly after the Armistice. This strange proceeding was justified by the fact that 
the dislocation of the exchanges was now so great that local importers who had imported and paid for these goods some time ago now made a larger profit, in consequence of the fall in the value of Turkish currency, if they resold them at a loss in terms of pounds, than if they sold them in the Turkish capital. The journalists who have been touring the "enemy countries" have come back with glowing stories of the prosperity of those areas based upon the fact that they could live in the best hotels and enjoy exquisite meals at a cost in pounds which was ridiculously small. At this moment, one set of men is being thrown out of work because the cost of foreign goods in terms of pounds is much less than the cost of similar goods manufactured in this country, whilst another set of men is unemployed because the goods they used to make are so high in price that the foreigner cannot afford to buy them.

Looking at the situation statistically, a Frenchman who left $£ 100$ in an English bank at the outbreak of war, which cost him about 2,525 francs, can now sell the money for about 5,700 francs. An Englishman who had 100 dollars in New York at the outbreak of war now finds that the money is worth 486/344ths of what it was worth at the time of investment. One thousand English pounds bought 19,450 Swiss francs on February 4, 1920 , and bought 2,650 more on November 17, 1920 . So we might go on, but these illustrations will be enough. Putting it into terms of commodities, every time the dollar increases in value in terms of the pound, the price of bacon and wheat and lard from America will rise in price in shops here. Tea growers are cutting down their production, and rubber growers are doing likewise, not because rubber or tea are not desired, but because Central European countries have so little money that they cannot afford to buy the tea or the rubber.

\$2. "The foreign exchanges" is one of those unfortunate phrases, the meaning of which is never clearly defined, because it is used in different senses in different 
contexts. The phrase may refer to fluctuations in the relative value of different currencies in the exchange market, and this is the essence of such remarks as that " the foreign exchanges have moved against us." When people are said to "buy foreign exchange," however, the phrase refers to what is bought, not to the price at which it is bought. When, on the other hand, "the foreign exchanges" are spoken of, the reference may be either to the thing bought, or to the prices at which it is bought, or to the institutions through which the commodity is bought. In addition to this extreme looseness in the meaning of the principal word itself, the experts who make a living from the purchase or sale of "foreign exchange" have invented a technical jargon of their own, which the City journalists also use in their articles, which is very useful to those who understand it, but is highly exasperating to those who do not know, but would like to, and a source of mental confusion to those who think that they know, but do not, and who substitute technical slang for thought.

In this chapter I am going to begin our subject by explaining "what it is all about." I am going to leave the theory, if there is one, severely alone for the moment, and will confine myself to an outline of what the foreign exchanges really are.

§ 3. The foreign exchange market exists, first, to provide debtors with the means to pay their debts, when those debts are contracted in the money of a foreign country, by giving them the opportunity of exchanging the money of their own country for something which will enable their creditors to obtain the money they desire. The foreign exchanges exist, secondly, in order to give persons to whom debts are owing in foreign currencies the opportunity to exchange these rights to foreign currency into the money of their own country.

It sounds a truism, but it is nevertheless a matter of considerable importance that debts are contracted in terms of money, and that debts owing to persons living 
in a foreign country are contracted, as a rule, in the money of the country in which the creditor happens to be living. The money of a country can consist either of gold or silver coin, and of paper pieces nominally equal to such a defined weight of gold or silver, but at times actually not so exchangeable.

We must from the very beginning learn to consider the foreign exchanges as a piece of mechanism. The fiscal controversy has made most people conversant with the jargon that "imports pay for exports" or " exports pay for imports." These phrases may be true enough, properly interpreted, but the fact that in the long run goods are offset by goods is not in contradiction to the fact that in the short run debts are contracted in terms of money, and that consequently a mechanisn by which such debts can be paid is required. Moreover, the statement that goods pay for goods is unduly narrow, for debts can arise on other grounds than the mere purchase of concrete things.

At this stage our real difficulties begin. It is very easy to start from the fact that the foreign exchanges arise from the necessity of settling foreign indebtedness, and to go on immediately to the conclusion that what is bought and sold in the foreign exchange market is the foreign currency itself. But this is not the case. The foreign exchange market deals in evidences of indebtedness. These evidences of indebtedness consist overwhelmingly of Bills of Exchange, but they may also consist of promises which inside a particular country may be taken in discharge of debt. That is, the commodities dealt in on the foreign exchange market consist of two species of things-paper money and Bills of Exchange of different types. Paper money is to be classed with Bills of Exchange because, outside the country in which it is issued, it possesses no rights greater than those of any other promise to pay. Inside the country in which it is issued the Government may decree that it must be accepted at its face value, but this mandatory power of a Government ceases at the frontier. Outside the limits 
of the country a bank note or a Government note is a mere promise.

In other words, Bills of Exchange and paper money share the disqualification that the holder of them cannot use them directly as money in the country in which the holder lives, so long as he is living in a different country from the person from whom he received the bill or the note. Even inside the same country a Bill of Exchange cannot be used directly as money, though Government paper money or a bank note can. Outside the limits of such a country the only thing that can be done with them is to sell them to someone else who has payments to make in the country from whence they come, or to send them back to such a country to be used in the purchase of things that can be sold in the holder's country, or for the purpose of getting gold and silver which command an easy sale and are easily transportable.

The holder of a promise to pay can therefore do one of two things with it. He can sell the promise to some one who will use it to settle a debt, or he can use it as a means of purchasing other things with it in the country from which the promise comes. The person who has a debt to settle in a foreign country can either buy a promise which will give him command of money in the country in which his creditor lives, or he can send to that country something which is saleable there, using the proceeds to pay his debtor. The foreign exchange market only comes into account directly so long as individuals choose to sell or buy evidences of debt, in place of sending these evidences back to the country for collection and further use of the proceeds there; or when the debtors buy such evidences, instead of sending to the creditors' country something which is saleable there, and hand the proceeds to their creditors. If an individual can do one of two things with an object, it is obvious that he will use it in that way which will pay him best. If an obligation resting on an individual can be met in either of two ways, it is equally obvious that he will choose the way which costs him least. 
The result is that if the holder of a promise to pay money can deal with it in either of two ways, the amount he will take for it in one of its uses will depend upon the amount he can get for it in the other of its uses. Similarly, if a person having a debt to meet in a foreign country can settle it in one of two ways, he would not give more for a promise than he would have had to pay in the aggregate to settle his debt in any other way.

Now, this general principle meant, in the world before the war, when nearly every country was using gold and silver as currency, or using a paper currency which was freely convertible into those metals, and when the metals were themselves freely exportable, that no one would give for a promise more than it would have cost him to get the equivalent amount of gold or silver necessary to meet the face value of the debt, and to ship that bullion or coin to his creditor. And, equally, the fact that gold or silver coin and bullion were easily obtainable meant that no creditor having a promise in his possession would sell that promise for an amount which was less than the cost of sending the promise to the country in which it was payable, converting the proceeds into bullion or coin, if the bill was not directly paid in coin, and shipping that bullion back again and selling it in the bullion market, or getting a bank to do it for him. If the cost of this bullion movement remained constant, then the limits within which the price of promises moved remained constant also. If the cost of such shipments increased, then the limits of the fluctuation of the prices of promises increased also; if the cost of such shipments declined then the limits of the fluctuations of promises narrowed. Every variation in the cost of the alternative would either widen the limits or narrow the limits within which the prices of bills or other promises could vary. If a debt owing to an Australian cost the debtor in London an additional $6 \mathrm{~d}$. per $£$ to settle if he sent actual sovereigns, then he would prefer to buy a promise if that cost him less than an additional $6 \mathrm{~d}$. per $\ell$. If the owner of a promise to pay, payable in Australia, could sell it for more than he would 
have got if he had sent the promise to Australia, and had the actual gold remitted to him, he would have sold the promise in London.

Now this is not the same thing as saying that in fact large amounts of gold or silver were sent about the world in consequence of this option having been exercised. All that is said is that if the prices of promises were allowed to rise or fall above or below a certain point, then gold would have been sent. In practice, these shipments were avoided by preventing such rises or falls as would have involved these bullion movements taking place on a large scale.

Further, the absence of the possibility of bullion shipments does not mean that there are no limits to the fluctuation in the prices of promises. Bullion is not the only thing that can be sold for the purpose of using the balance to pay debts with. The shipment of bullion is merely the most spectacular instance of a general principle that one way of meeting a debt in a foreign country, instead of buying a promise, is to export something to that country which can be sold there and the proceeds utilised for the payment of debts. What other methods there are we shall see later on.

$\$ 4$. The amount of promises available at a particular moment in a given centre will depend on the amount of indebtedness incurred by inhabitants of foreign countries to inhabitants of the country in question, and payable at that moment. The amount of such promises required by a particular centre at a particular moment will depend on the amount of indebtedness incurred by inhabitants of that country to inhabitants of foreign countries, and payable at that moment. The prices of promises in that centre will rise if the country has to pay more than it is being paid at that moment, and will fall if the market is offering more bills than debtors immediately require. It makes absolutely no difference how this indebtedness has been incurred, although the habitual way of describing the fact of relative indebtedness at any particular moment 
as " the balance of trade" leads a large number of people to think that relative indebtedness is due exclusively to the movement of concrete things. This is quite wrong, and it is a still greater mistake, into which even City editors of newspapers are constantly falling, to attempt to prove what the state of relative indebtedness is from a cursory examination of the current trade statistics. The "balance of trade" throws some light upon the question of relative indebtedness, but it does not follow that even if we know all about the relative state of indebtedness we have solved all the problems. For we want to know why relative indebtedness is what it is. In any case, current movements of goods are not the only causes of indebtedness. Any reason whatsoever which leads people to desire to pay money in a foreign country, and any reason whatsoever which gives an individual a right to foreign money, adds to the demand for promises, and adds, alternatively, to the supply of such promises.*

§ 5. If a debt in America is settled by the despatch to the American creditor of a promise to pay money due from someone else in America, and if a debt to an Englishman by someone in America is settled by sending to him a promise by some other Englishman to an American, what is the net effect? The net effect is, of course, that international debts are settled by the method of offsetting debts owing to and owed by persons living in the same country. The problem is, in the first instance, merely one of putting the appropriate debtor in touch with the appropriate creditor. This the Bill of Exchange enables people to do with the greatest ease. For Bills of Exchange are transferable by endorsement, that is, a promise by $A$ that he will pay money to $B$ can be transferred by $B$ to $\mathrm{C}, \mathrm{D}$, and $\mathrm{E}$, either in exchange for money, i.e., sale or in payment of his own debts. If $\mathrm{A}$ who has promised to pay the bill does not do so, then all the intermediate persons in the chain, including the original "drawer," are liable to the last holder of the bill. All that is required

- The whole of this question is dealt with in detail in Chapter III. 
is a middleman who will buy the bills from the holders who want money on the spot, and who will sell them to individuals who will give the middleman money on the spot, and in return for the bill, which they can send to their creditors, who collect the money from the original debtors, or whose creditors in turn will collect the money.

§ 6. Since Bills of Exchange arise through transactions between individuals, it is fairly clear that their value will depend, apart from the general state of relative indebtedness, on their merits as promises, and the time when they are due for payment. If I buy a promise which is not going to be due for six months, I am certainly not going to give as much for it as I would for a promise that will give me money as soon as it is presented to the person who has incurred the debt. So, also, it is quite clear that if I hold a promise by a reputable person, I shall get for it more than I would have got if the buyer knew nothing about the standing of the individual who has promised to pay it. Consequently, the prices of promises in the foreign exchange market will vary, in part according to the general conditions of " supply and demand," and in part according to the particular class of bill I am selling. The next thing to do is obviously to investigate the foreign exchange market as an actual phenomenon.

\$ 7. Before we pass on to this subject, there is one more point which requires a word. It is quite natural to ask, though I find that a considerable number of students are rather ashamed to do so, how people are ever got to give the promises to pay, which I have called Bills of Exchange. Everyone can see the advantages of Bills of Exchange as instruments of transfer, but how are people got to promise that, on a specified day, they will pay money to a specified person? There is nothing very much in it as soon as one faces the fact that sellers want security and will not sell goods, or, what is the same thing, will not deliver goods unless the person who buys them 
will tie himself by a written promise. The actual procedure is as simple as ABC. The goods are not delivered unless and until the buyer gives the seller or his agent the promise asked for. Suppose the terms of sale are that the goods are to be paid for three months after the date of delivery. The goods are delivered, or, what is very much the same, the buyer is given the documents which will enable him to get the goods out of the ship or the warehouse where they are lying, on signing a promise to pay in 80 days after the date of promise or " acceptance." If the buyer is a merchant in Lisbon, and the seller a merchant in London, the documents are sent to a local agent of the exporter, usually a bank, which, in the event of the buyer not accepting, will store the goods at the expense of the exporter, and will await his orders as to their future disposal. This is the commercial practice which is generally described as D/A, or " Documents against Acceptance." The seller having got his bill accepted in this way can then sell it for cash, or get an advance against it from the bank.

This is only one way in which bills come into existence, based upon a commercial transaction. There are plenty of other ways which we might have taken as illustrations. If an American bank gives an introduction to an American millionaire to a London bank, which cashes his cheques, by means of which he pays his hotel bills at the Savoy, then the London bank will be out of funds to the extent to which it has advanced money in this way. It gets its money back by selling bills on the New York bank to the extent of the advances so made, and these drafts may be bought by a bacon importer who has bills to meet on the New York Produce Exchange. Or they may be bought by the British Government which has to collect funds in New York to meet its indebtedness there. Technically, the millionaire will draw his cheques against a "Letter of Credit." But the net effect is that debt will have been created, and that, in consequence, London is entitled to so much money in New York, which is collected by selling a "Banker's Draft" against the sums due. 


\section{HOW TO READ THE EXCHANGE ARTICLE.}

$\S 1$. All the following extracts are taken from the Money Market Page of The Times issue of Wednesday, November 24, 1920.

\section{No. 1.-ForeIgN EXchanges.}

Fluctuations in some of the leading exchanges were unusually wide yesterday. New York touched $\$ 3.55$ and $\$ 3.49 \frac{1}{2}$, closing only $\frac{1}{4}$ c. lower on the day at $\$ 3.50 \frac{1}{8}$. Marks ranged between 214 and 245, closing at 236 $\frac{1}{2}$, against $233 \frac{1}{2}$ on Monday. Paris touched $55 \mathrm{fr}$. $80 \mathrm{c}$.

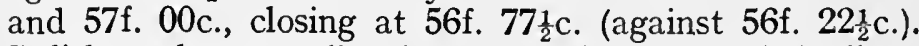
Polish marks were offered, the rate closing at 1,575 sellers, and Austrian kronen also depreciated, the final rate being $1,162 \frac{1}{2}$ to the pound. The following rates were current yesterday :-

\begin{tabular}{|c|c|c|c|c|}
\hline Place. & $\begin{array}{l}\text { Method of } \\
\text { Quoting. }\end{array}$ & $\begin{array}{c}\text { Par. of } \\
\text { Exchange. }\end{array}$ & ber 23 . & November 22 . \\
\hline $\begin{array}{l}\text { New York } \\
\text { Montreal } \\
\text { Paris } \\
\text { Brussels } \\
\text { Italy } \\
\text { Berne } \\
\text { Athens } \\
\text { Helsingfors } \\
\text { Madrid } \\
\text { Lisbon } \\
\text { Amsterdam } \\
\text { Berlin } \\
\text { Vienna } \\
\text { Prague } \\
\text { Warsaw } \\
\text { Bukarest } \\
\text { Christiania } \\
\text { Stockholm } \\
\text { Copenhagen } \\
\text { Alexandria } \\
\text { Bombay } \\
\text { Calcutta } \\
\text { Madras } \\
\text { Hongkong } \\
\text { Yokohama } \\
\text { Shanghai } \\
\text { Singapore } \\
\text { Manila } \\
\text { Rio de Jan. } \\
\text { B. Aires, T.T. } \\
\text { Valparaiso, 90 da } \\
\text { Mlontevideo, TT. } \\
\text { Lima } \\
\text { Mexico } \\
\end{array}$ & 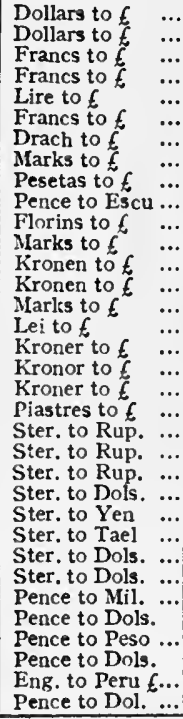 & 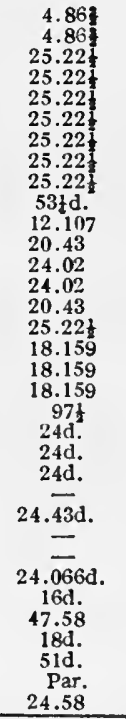 & 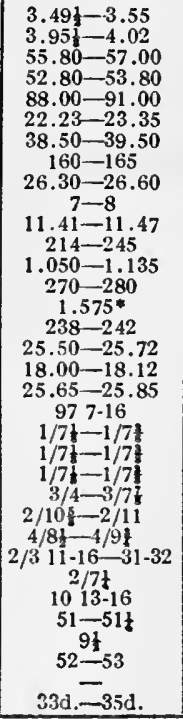 & 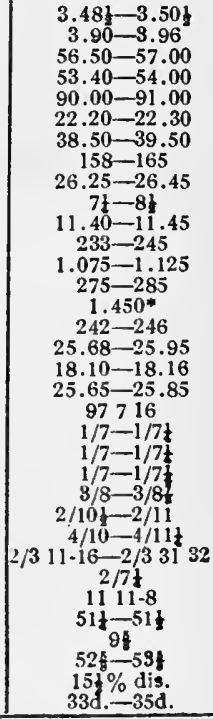 \\
\hline
\end{tabular}

* Sellers. 
On 'Change rates on France, Belgium, Italy, Germany, Spain, Scandinavia and Buenos Aires moved against this country. Swiss, Dutch, Finnish, Portuguese, Athens, New York and Rio currencies depreciated in value. The following were the quotations :-

\begin{tabular}{|c|c|c|c|c|c|c|c|}
\hline \begin{tabular}{l} 
Amsterdam \\
Belgium \\
Paris ... \\
Switzerland \\
Germany \\
Genoa ... \\
Athens ... \\
Rio $\ldots$ \\
Spain ... \\
Lisbon and O \\
Copenhagen \\
Christiania \\
Stockholm \\
Helsingfors \\
Buenos Aires \\
New York \\
\multicolumn{1}{c}{,. }
\end{tabular} & $\begin{array}{l}\ldots \\
\ldots \\
\ldots \\
\ldots \\
\ldots \\
\ldots \\
\ldots \\
\ldots \\
\ldots \\
\ldots \\
\ldots \\
\ldots \\
\ldots \\
\ldots \\
\ldots \\
\ldots \\
\end{array}$ & $\begin{array}{l}\ldots . . \\
\ldots . \\
\ldots . \\
\ldots . \\
\ldots . \\
\ldots . \\
\ldots . \\
\ldots . \\
\ldots . \\
\ldots . \\
\ldots . \\
\ldots . \\
\ldots . \\
\ldots . \\
\end{array}$ & \begin{tabular}{l} 
Cable \\
Cheque \\
Cable \\
Three month \\
Cable \\
Three month \\
Cable \\
\multicolumn{1}{c}{...} \\
Cable \\
Three month \\
Cable \\
Cable \\
Cable \\
Cable \\
Cable \\
Cable \\
Cable \\
Demand \\
\end{tabular} & $\begin{array}{l}\ldots . \\
\ldots \\
\ldots . \\
\ldots \\
\mathrm{hs} \\
\ldots \\
\ldots \\
\ldots \\
\ldots \\
\ldots \\
\ldots \\
\ldots \\
\ldots \\
\ldots \\
\ldots \\
\ldots\end{array}$ & $\begin{array}{l}\ldots . \\
\ldots \\
\ldots \\
\ldots \\
\ldots \\
\ldots \\
\ldots \\
\ldots \\
\ldots \\
\ldots \\
\ldots \\
\ldots \\
\ldots \\
\ldots \\
\ldots \\
\ldots \\
\ldots\end{array}$ & $\begin{array}{l}11.44 \\
53.00 \\
55.80 \\
56.56 \\
22.28 \\
22.78 \\
225 \\
88.00 \\
38.50 \\
98 \\
26.45 \\
44 \\
7 \\
25.45 \\
25.58 \\
18.05 \\
158 \\
51 \\
3.51 \\
3.521 \\
\end{array}$ & $\begin{array}{l}11.48 \\
53.50 \\
56.40 \\
57.15 \\
22.38 \\
22.88 \\
235 \\
90.00 \\
39.50 \\
10 \% \\
26.65 \\
44 \frac{1}{8} \\
8 \\
25.65 \\
25.68 \\
18.15 \\
168 \\
51 \% \\
3.54 \\
3.56 \\
\end{array}$ \\
\hline
\end{tabular}

The price of gold declined a further 1s. $2 \mathrm{~d}$. to $115 \mathrm{~s}$. $10 \mathrm{~d}$. per ounce (fine), and American buyers again took all available supplies.

\section{No. 2.-Money and Exchange.}

\begin{tabular}{|c|c|c|c|c|}
\hline 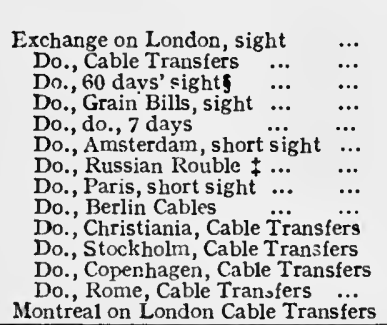 & $\begin{array}{l}\cdots \\
\cdots \\
\cdots \\
\cdots \\
\cdots \\
\cdots \\
\cdots \\
\cdots \\
\cdots \\
\cdots \\
\cdots\end{array}$ & $\begin{array}{l}\ldots \\
\ldots \\
\cdots \\
\cdots \\
\cdots \\
\cdots \\
\cdots \\
\cdots \\
\cdots \\
\cdots\end{array}$ & $\begin{array}{l}\text { To-àay. } \\
3.501 \\
3.51 \frac{1}{6} \\
3.47 \frac{1}{5} \\
3.508 \\
3.498 \\
3011-16 \\
0.85 \\
6.21 \\
1.48 \\
= \\
\overline{-} \\
3 . \overline{9} 13-16\end{array}$ & $\begin{array}{c}\text { Prev. day. } \\
3.49 t \\
3.50 t \\
3.46 t \\
3.49 \\
3.481 \\
301 \\
0.95 \\
6.21 \\
1.54 \\
13.64 \\
13.60 \\
3.88 \\
3.96 \frac{1}{2}\end{array}$ \\
\hline
\end{tabular}

§ Prime Bankers.

$\ddagger$ Cents per Rouble.

$\S 2$. We have here three tables of exchange rates. The table I have headed No. 2 represents Money and Exchange in New York, the to-day and the yesterday therein referred to are thus November 23 and November 22 respectively. The long column, which fills the greater 
part of the first table, gives the rates for telegraphic transfers as current on the dates mentioned at the places therein referred to. The official London rates as they used to be quoted "On 'Change" occupy the lower portion of the first table. Finally, the first table contains the current price of fine gold, and begins by summing up the movements in the rates. The "On 'Change" Table appeared twice a week-on Wednesdays and on Fridays-the official market used to meet at the Royal Exchange on Tuesdays and on Thursdays; the other two tables appear every day.* We must now begin to examine what these tables respectively mean.

There are two sets of problems which have to be clearly distinguished from one another. The first group, which is the most important, concerns the influences which affect the rate. The second concerns the method of quotation. By the influences affecting the rate I do not mean the general influence of "supply and demand," but the specific qualities which differentiate the various

* This Chapter was originally written at the end of November, 1920. Since that time, as the following extract from The Times of December 24, 1920, shows, changes in the organisation of the London exchange market have made it necessary to change the tense of the text. I leave the description of the "On "Change" Table, because it is one illustration of methods of quoting rates of great historical imporcance.

\section{The End of On 'Change.}

"An institution which has existed in the City for generations is about to come to an end, owing to the altered conditions existing at the present day. We refer to the meetings of merchants, bankers, and brokers which take place on the Royal Exchange, each Tuesday and Thursday (post days, as they are called), for dealings in foreign exchange. Originally these dealings were chiefly in the form of bills ; nowadays, with the telephones and telegraphs in operation, dealings in foreign exchange take place at a furious pace all day long, and they are mainly in cable transfers, which fluctuate every few minutes. The necessity for the old post-day meetings has therefore largely disappeared; hence it has been decided for the present to discontinue these bi-weekly meetings after Thursday next."

This statement is liable to mislead the unwary. It is quite taue that professional operations in exchange take the form mainly or cable transfers, but, of course, it does not imply that Bills of Exchange for commercial purposes have disappeared. So long as timebills exist, there will continue also the problem of calculating the "long rate," for which, soe $\S 4$ on p. 23. 
classes of market supply. Of these differentia there are two. Of these two one is the length of life of the bill which is to be sold or bought, the other is the intrinsic merit of the bill as a bill.

$\S 3$. Let us see how these considerations work. If I am promised money in three months' time, assuming the rate of interest being 5 per cent., obviously I will not give the whole of the future capital value of the money now in exchange for the promise. If I did the promisor would earn, and I should lose, the interest on the money for three months. Consequently, the longer the period for which payment is postponed when a bill is created, the less the present value of the bill if it is sold to a third person. Conversely, the more quickly a person buying a bill is entitled to his money after purchase, the more he will give for the bill, other things equal. That bill will command the highest return, which will give the buyer command over money at once and with the least risk of non-payment.

Now, both these facts are brought out very well by the New York quotations, and this is the reason for its insertion here. The reader will see that a large variety of bills are quoted even on the same centre. Thus on London there is a sight rate, a sixty-day rate and a cable rate; in addition separate rates for grain bills, i.e., Bills of Exchange drawn against shipments of wheat. The sixty-day rate is specifically said to be the rate for "Prime Bankers Bills," the meaning of which we must seek to elucidate later.

Cable transfers represent bills which give money as soon as the telegram reaches the other centre; hence their general designation of Telegraphic Transfers. It is sometimes thought that these transfers represent nothing analogous to a bill at all, but a moment's thought will show the absurdity of this. The volume of such cable transfers which can be sold at a given moment depends on the conmand over money which the seller has at that moment, and the volume of such transfers is thus governed 
by causes of the same kind which at any moment determine the amount of other bills which can be offered.

Next come "sight" bills. Sight bills are payable on demand, that is, on presentation to the drawee, from which we get the synonym " the cheque rate." In fact, of course, it takes some time before the money due on a sight bill is paid ; the minimum period before payment is the length of time it takes to send the bill to the centre where it is payable.

The "short sight " rate is rather an omnibus description. It includes, firstly, bills payable a limited period after sight, the limit being 8 days, which, with the customary three days of grace, makes eleven days: and bills of longer maturity, but having only a defined number of days-ten as a matter of fact-more to run, to which the three days must again be added.

The difference between the waiting period in the case of the sight bill and the three months' bill is thus 93 days, for it takes as long to get a "sight bill" to the centre where it is payable, as it does a "long bill."

$\S 4$. Since the difference in the prices of long and short bills, their intrinsic merits as promises being assumed to be equal, is determined in the first instance by the interest rate ruling in the centre where the bill is payable, what rate of interest we are thinking of at once becomes important. Here the matter is complicated by the fact that the rate of discount is very different for different classes of bills : and, even if this point is overlooked for the moment, in most centres there are at least two rates of discount, the official rate, which is charged by the central bank, and the market rate, which is charged by the private discounters, including in this term not only individuals, but banks and other impersonal institutions, so long as the central institution is excluded. These two rates, the official and the market rate, tend to move together, but not necessarily very closely. Consequently, it is not always easy to distinguish what rate it is that is being used to differentiate the prices of different classes 
of bills. But it is fairly clear that the seller of the best bill will charge the highest price for it : which means that the lowest rate of discount is always applied to these bills, which in turn means that, given two bills of equal length of life, the present value of the better bills will be higher than the present value of the inferior bills, which are always discounted at the higher rates.

The basis for the estimation of the long rate, that is, for Bills of Exchange with so many days to run, is the sight rate. But it does not follow that the long rate will always move exactly as the sight rate; there may be independent movements. But as soon as these take place, assuming that no change in the rate of discount has taken place, speculation will at once begin, in the manner to be described in a subsequent chapter, and this will have the effect of bringing the two rates to their normal relationship again.

What, now, as to the kinds of bills? We may distinguish, to begin with, "trade bills" and " bankers' bills." The former, as the name implies, are bills which arise in the course of trade, the latter are bills drawn on banks. That is the obvious line of distinction, but in fact, the trade bill may acquire some of the virtues of a bank bill by the simple process of people arranging that they shall be accepted by a bank on behalf of the drawee, that is, goods are shipped to B, by A, but instead of the bill being accepted by $B$, it is accepted by the X.Y.Z. Bank, in return for a commission. This process of acceptance was formerly specialised in the hands of the " accepting houses,"* but there is now vigorous competition between them-and the more modern foreign banks, the "foreign" branches of the joint stock banks, and the colonial banks, who all show considerable amounts of liability on account of acceptances in their balance sheets. Hence we must distinguish two classes of bank bills, the finance bill, the virtues of which we shall discuss in a later chapter and the trade bill drawn under an acceptance credit, and thus converted into a bank bill in return for a commission.

* That is, private partnerships. 
§5. So far, then, we have been dealing with the causes which influence the prices for different classes of bills. We must now turn to the next matter: the method of quotation.

We are always in the habit of overlooking that we can quote the price of a thing in two ways. We can speak of the thing as a unit, and compare the differing amounts of money which that thing costs us. Or, we can quote a fixed amount of money, and speak of the varying amounts of the article which we can buy with the fixed amount of money. The actual method chosen is determined by convenience. When it is difficult to imagine the article except as a single whole, we always quote varying amounts of money. Thus, we say, a hat costs so and so much. Suppose hats used to cost 10 s., and now cost $20 \mathrm{~s}$. We might just as well say that 10 s. buys half a hat as say that a whole hat costs us 20s. now. But, in fact, it is easier to think of hats as units. On the other hand, when we think of the cost of living, we generally speak of our income as a fixed unit, and compare the varying amounts of things which that income enables us to buy at different times. It is just as correct to think of the things as a fixed amount, and ask how much money we require at different times to buy those things. And, in fact, when indices of the cost of living are drawn up, the things are taken as the unit, and the amount required to buy them represents the fluctuating element.

Now, all the trouble which people give themselves in thinking of the foreign exchanges arises from the fact that they overlook this possibility of counting or reckoning in two ways.

Let us now look at the first table in this chapter. The first column of the first table states the "Method of Quoting.'

It will be seen that in all the centres, until we get to the Indian ones, the method of quoting is the local money to $£ 1$, the only exception being Lisbon. If I give varying amounts of the local currency for $£ 1$, it stands to reason that the less I have to give of local currency for one 
pound, the better pleased I shall be. If, on the other hand, I buy a varying number of pounds or shillings or pence with a fixed amount of local currency, as I do in India, and in the South American centres, the more English money I buy the better off I shall be. So that, in a centre which quotes its own currency, the higher rate indicates high prices, whilst in a centre which quotes currency which to it is the foreign currency, the higher the quotation, the cheaper prices are becoming.

[In the case of the "On 'Change" Table, it will be noted that sometimes the one, and sometimes the other method of quotation is preferred: thus the Lisbon, the Rio and the Buenos Aires rates are all quoted in pence, corresponding to the method of quotation in these centres themselves.]

What is the result of this? If both centres quote the same rate, it means that what is a dear rate in one centre, the one, namely, in which the rate is the price in the local currency, will be a cheap rate in the other centre, the one, namely, in which that rate represents the price of the foreign currency.

We must go back to the long and short rate again. When a centre quotes the foreign money, then the long rate will be above the short rate : that is, a seller must give more in the future for money down on the spot. On the other hand, when the centre quotes a fluctuating amount of domestic currency for an invariable amount of foreign currency, then the short rate will be above the long: that is, the buyer will give more for a promise which will put him in funds at once, than he will for a promise which will only give him funds in the future. This general fact finds expression directly in the quoted rates.

Once the underlying principle of the twofold method of quotation has been grasped, there is no difficulty in seeing what the meaning of "rising" and "falling rates" is. When a centre quotes the foreign currency, the rate will rise when a smaller amount of foreign currency can be bought, and the rate will fall when a larger amount 
of foreign currency can be bought. When the centre quotes a fluctuating amount of domestic currency a falling exchange means that a smaller amount of home currency will suffice, whilst a rising exchange will mean that a larger amount of home currency must be given, to obtain a given unit of foreign currency. In this case, falling rates reduce, and rising rates increase, the expense, just as in the previous case ; only, in the first case, a fall in exchange is expressed by a rising quotation, a rise by a falling quotation; in the second case, a fall is expressed by a falling quotation, and a rise by a rising quotation.

§6. This brings one to the question of what is meant by "favourable" and " unfavourable" rates. In the comments on the "On 'Change" Table it will be noted that certain rates are said "to move against this country," which is a synonym for becoming less favourable or more unfavourable.

Now, considering that bills are both bought and sold : a rate which is favourable to one party may be considered as unfavourable to the other, in the sense that if a buyer buys cheaply or a seller sells dearly, the seller in the first case and the buyer in the second is disadvantaged in the bargain. But " unfavourable" and "favourable " as expressions have nothing to do with this relationship; they have reference to the relative values of the two currencies considered as a whole. If a rate is unfavourable, say to New York, it means that dollars are falling in value relatively to that currency, and that currency is rising in value relatively to dollars. If the local quotation is in terms of the local currency, then an unfavourable rate is expressed by a rise in the quotation, a favourable rate by the fall in the quotation : if the local quotation is in terms of the foreign currency, then a favourable rate is expressed by a rise in the rate, and an unfavourable rate by a fall. But a rise or fall from and to what? It will be noted that column three of the first table of No. 1 is headed "Par of Exchange." The 
favourableness or unfavourableness of the rate is judged by the movement from or towards this parity, the method of quotation being given.

§7. But what is the "Par of Exchange" ? At the moment of writing, the par is nothing but a convenient " unit of reference," by which we can measure movements in the rate: but in the days before the war, the par of exchange was the unit of reference because it expressed the fixed relation between the gold contents of the standard money of the two countries: or more generally, the relative amounts contained in the gold coins, or freely obtainable by them. Thus the par of exchange between London and New York expressed the fact that $£ 1$ gold contained as many grains (113) as $\$ 4.86 \frac{2}{3}$ U.S.A. money, or $25.22 \frac{1}{2}$ gold francs, or 20.43 gold marks. It will be noted that in some cases, e.g., Shanghai, Singapore and Hong Kong, no par is given : this is due to the fact that the local coin is a silver coin which has no fixed relation to gold. Indian places, on the other hand, do have a fixed par, because, at the moment, an Indian rupee is nominally $24 \mathrm{~d}$., or $1-10$ of a gold pound.

At the present moment the money of most of the countries mentioned is not convertible into any amount of gold fixed by law. Consequently, the par of exchange is no longer the effective par of exchange at all. Thus, $\$ 4.86 \frac{2}{3}$ is still worth 113 grains of gold; and if 113 grains of gold could not be got in exchange for $\$ 4.86 \%$, people could get gold dollars and melt them down. But in the United Kingdom at the present time a gold sovereign cannot be melted down or exported, with the result that the price of fine gold in terms of English legal tender is much above the rate at which the Mint is prepared to give gold pounds in return for gold bullion. Thus the Mint price is $£^{3} 17 \mathrm{~s}$. $10 \frac{1}{2} \mathrm{~d}$. for an ounce of gold 11-12 fine, or $£ 44 \mathrm{~s}$. 115 -11d. for an ounce of fine gold. If the market price rose above this, people used to melt sovereigns. Now they are forbidden to do so, and dire results to them will follow if they try to do so. The result 
is that fine gold rose considerably above the Mint parity.

"Oh, yes," people say, " this is due to the American premium." This is a complete misconception. There is no premium in America, where gold, in terms of dollars, is as cheap as it used to be. (In terms of goods, gold in America is about half as dear as it used to be, that is, it is much cheaper.) The preminm on gold is here, and it follows that a fluctuation in the American rate will always be accompanied by a fluctuation in the price of gold. For the gold is sold in America at a fixed price in dollars. If dollars rise in value, the holder of gold will get more pounds for his dollars ; if dollars fall in value, the holder of gold will get the same number of dollars but fewer pounds. So long as he has the option of selling in London or in New York, a holder of fine gold will only sell in London if he can get as many pounds here as he would have got if he had sold in America, and sold pounds against his dollars-so long as he is allowed to sell in either centre. During the war he was not; South African miners had to sell here and got only $f^{4} 4 \mathrm{~s}$. 11 5-11d. per ounce fine for their gold. Old-fashioned text-books on exchange still contain elaborate discussions of the " gold points."

All this came to was that, if it cost more to buy a bill than to send gold, gold would be sent : for the gold was fixed in price, and the only expense incurred was that of loss of interest, freight and insurance. In the spacious days before the war, when people were not regarded as criminals because they sent gold away, a rise in the price of foreign bills was regarded as " unfavourable," because, after the point had been reached at which it was cheaper to send gold, gold was sent. The gold was got in the shape of gold or bars at a fixed price. To buy fine gold in London to-day is no cheaper than it is to buy dollars, simply because the sovereigns which could be bought at a fixed price in terms of Bradbury notes cannot be melted or exported without a licence. Before the war, all that was necessary was to cash $£^{5}$ notes, and no one would give more for new gold than the cost of getting gold by 
cashing notes at the Bank of England, and this cost was fixed by law.

When, on the other hand, the price of foreign money fell so much that a holder preferred to hold to maturity and have gold sent to him, the sale was regarded as favourable, because gold moved into the centre. The phrases, therefore, refer to a state of affairs no longer in existence so far as most European countries are concerned, though it is interesting to observe that it is true of the post-war revolutionary Mexico, also of the United States and Argentina.

$\S 8$. We have not yet exhausted the interest of the Exchange Tables, however. It will be noted that in both the tables quoted in No. 1, there are two prices quoted on each of the two days in the first case, and on the single day in the second. In the case of the foreign quotations, these two rates represent "Buying Prices," and "Selling Prices." That is, when an exchange dealer is selling, he quotes two rates, at one of which he is prepared to sell pounds in London, at the other of which he is prepared to buy pounds in London. The lower of the rates represents the buying price, the higher of the rates, the selling price, of pounds in London in that centre, so long as the centre quotes its own currency. When the centre quotes in terms of pounds, the higher price represents the buying price, the lower the selling price.

[The London 'On Change Table, according to $\mathrm{Mr}$. Spalding,* was much less logical. In the case of long paper quoted in the foreign currency, the second of the two rates indicated commercial, the first, bank bills; whilst in the case of sight bills, the second rate included "short-sight," and as this contains, with some time more still to run, the price is less favourable. In our Table no sight rates are, as a matter of fact, given.]

§ 9. When two centres use the same currency, instead of giving the actual amount of money which must be

* Foreign Exchange and Foreign Bills, 3rd Edition, p. 52. 
given for a unit of the currency in the other centre, or the amount which can be bought in that other centre for a unit of currency in the first centre, it is possible to give merely the amount by which the same currency is dearer or cheaper in the one centre than in the other. Thus, the Economist for November 20,1920, gives the following rates as being quoted by South African Banks on London, from November 5, 1920, onwards :-

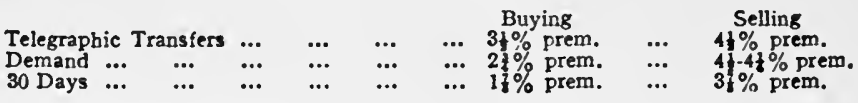

All that this comes to is that the bank will for $£ 100$ in London, transferable by cable, give $£ 10310$ s., and will sell $£ 100$ on the same basis for $£ 10410$ s. Demand drafts will be bought for $£ 102$ 15s. per $£ 100$, and sold for $£ 104$ 10s. or $£ 104$ 5s. 30 -day bills will be bought for $£ 101$ 17s. 6d. and sold for $£ 103$ 17s. $6 \mathrm{~d}$.

\section{CHAPTER III.}

\section{EXCHANGE · FLUCTUATIONS AND THE, BALANCE OF INDEBTEDNESS.}

$\S 1$. It now becomes necessary to begin the examination in more detail of the problem which was touched upon lightly in the first chapter, viz., the limitations upon the range of fluctuation of the rate of exchange. It was implied in the first chapter that there were limits to the degree of fluctuation, and it is of the highest importance to examine this problem very carefully.

\$2. In this chapter I am going to assume one thing which, throughout the course of the chapter, the reader must keep carefully in mind. I am going to assume that the currency is a gold currency, or, if not itself gold, is convertible into gold at par, that is, that the paper money of the country is convertible into gold at 
the legal ratio, and that the gold is exportable freely in unlimited quantities.

Besides this assumption, there is one further point which requires to be brought into clear relief. The statement that there are limits to the range of fluctuation should not, one would imagine at first sight, be necessarily taken to mean that those limits are necessarily always the same. There are limits to the amount of food that a given individual is capable of consuming at a given moment, but this limit is not the same at all moments of an individual's life. We do not in ordinary conversation find the statement that "people eat a great deal when they come in from a walk" inconsistent with the statement that "sedentary work destroys the appetite," although even in the first case there will be a limit to the amount the most hungry pedestrian will consume. So there ought to be nothing surprising in the statement that though there are limits to the degree of fluctuation in the rates of exchange, those limits are not always necessarily the same. The simple explanation is that conditions have altered from time to time.

$\S 3$. The influences, or supposed influences, affecting the range of fluctuation, which will be examined in this chapter, are two in number, viz., gold movements and the balance of indebtedness. It is usual to say that gold movements limit the degree of fluctuation to the cost of transmitting gold in either direction, whilst movements within these limits are determined by the balance of indebtedness. Gold exports act, according to this theory, as a check upon the degree to which the balance of indebtedness can affect the exchanges adversely. The movement of gold "corrects" the exchanges, as people say. On the other hand, language is sometimes used which implies that gold exports did not " correct" the exchanges, but were only an incident connected with with the fluctuation of the exchanges, so that, were gold exports prohibited, the amount of indebtedness would remain very much the same, and with it the 
degree of fluctuation in rates. Thus Mr. McKenna, speaking at Manchester on November 17, 1920, said:

"In pre-war times, when in most countries the internal currency had an exchange value at or about its gold parity, gold had a particular use which it no longer has now. Small trade balances between any two countries could be settled by payment in gold, and as it is a commodity easily handled, and as its legal tender character is almost universal, it had a special value for this purpose. But to-day these conditions no longer exist. The wide variations of exchange have led most Governments to prohibit the export of gold, and it is little used now for settling international balances."

This seems to be rather begging the question. Were pre-war "balances" small because gold exports were allowed, or were these allowed because the balances were small ? Again, are post-war balances larger because gold is not allowed to be exported? Mr. McKenna would seem to dispute this, and to set up the theory, that small balances only are capable of being " corrected " or "settled." The possibility that both phenomenasmall gold shipments and small balances-are in themselves due to more deeply lying causes is not directly brought out.*

$\S 4$. In the form in which the relationship of fluctuations in the rate of enchange to gold exports and the balance of trade is usually put, there is a great deal that is erroneous. Gold exports, to begin with, are not in the least essential to correct the exchanges, provided that other articles can be exported. The nature of "an adverse balance," which gold exports are supposed to correct, is, in the second place, usually misconceived. Since a clearing up of this misconception is fundamental, I will begin with this matter.

* As a matter of fact, Mr. McKenna has elsewhere in his speech stated the correct theory; but has not realised that gold exports are only a special case of this general theory. The speech is printed in extenso in the November Circular of the London Joint City and Midland Bank Circular. 
What is meant by an adverse balance of trade? If we refer to the manner in which the phrase is habitually employed we find that there are ambiguities as regards both the time element and the scope of the "balance."

Let us begin with a statement of this sort: "Last year our imports from country $x$ amounted to $£ 500$ millions, but our exports only amounted to $£ 250$. It is therefore not surprising that the rate of exchange was permanently unfavourable to us." In other words, all that some people will find it necessary to include in the "balance" are the imports, which are all treated as debts, and the exports, which are all treated as credits But the matter is not quite as simple as this.

The imports into a country represent not only goods currently purchased, but goods for which payment is postponed. In addition, goods may be imported in payment of services rendered by inhabitants of this country to inhabitants of other countries. Further, among the imports are goods representing repayment of debt and interest on capital sums lent abroad. In other words, it is far from true that all the imports represent "debts," just as it is untrue that all the exports represent claims on foreign countries; for among our exports there may be goods representing payments for services rendered to us, interest payments by us, and repayment of capital claims, as well as goods for which current payment is expected and goods for which payment will be deferred; that is, our capital exports. This short statement ought to make it clear: (1) that we cannot arrive at the true "Balance of Indebtedness" by merely taking current trade statistics at their face value, or, in other words, the "Visible Balance" is not a true index of the "Real" Balance; (2) that when we are thinking of the Real Balance of Indebtedness, we must think not of the aggregate amount of indebtedness, but of the amount of indebtedness of all kinds, to be met within a defined period of time. Thus, it is of the greatest importance at the present time not to confuse the total indebtedness of the United Kingdom to the United States of America. 
with the amount falling due within the next six months. Arguments based on the aggregate indebtedness will lead one entirely astray if one is thinking of the immediate future.

§5. Confining ourselves to the indebtedness due during a given time, it is clear that if we are ever to understand the exchange situation, we must include among the elements for which we have to be paid services as well as goods, and we must distinguish among the imports those things which do not create current indebtedness but are payments to us which others are making by the shipment of material things. Equally, among our exports are included our payments for current supplies of services which inbabitants of other countries are rendering to us. Where do capital-debts and interest payments come in? They enter the totals in no other way than current supplies of goods. If a foreign country repays this country with some physical thing which is subsequently sent here, that thing will be entered in the trade statistics as an "import." If that country repays this country by transferring to us something which is not recorded, such as income rights, generally called " securities," all that will come in will be the income, if we choose to take this in the form of goods which are capable of transfer, and do not rather choose some form of payment, such as foreign travel, which we cannot import. So, among our exports are included goods which represent payment for current goods imported, goods representing payment of the instalments of interest and capital which we have to pay at that time, and goods representing new loans which we are making to foreign countries. If our debtors choose to be paid by travelling in the United Kingdom, or by buying country houses here, or by keeping the interest and capital here for reinvestment, there will be no physical export, but it does not follow we are not paying our debts. Finally, if instead of exporting goods from here to the United States, we export goods from India, to which we are entitled, but which we do not consume, to the United States, we pay our debts, not by 
increasing our exports, but by the process of diminishing our imports, the very thing that simple-minded persons think so very desirable.

§6. "All this," I imagine some reader saying, " is very nice and fine: but did he not say himself that we ought to unlearn the jargon about imports paying for exports, and vice versa? If he is not saying the same thing, he is saying something so like it that it wants a magnifying glass to see the difference." Now, the point is that the jargon I attacked in the first chapter assumes that all imports are debts and all exports are credits, which is not the case at all. In the second place, I know quite well that the next step in the argument is to link up all this movement of goods and services with the money side of the situation.

How does the account get settled in terms of money transfers? Nothing is simpler. Let us take the element which puzzles so many people at present, the debts of a government. Suppose the British Government has to pay $£ 125$ millions in the United States : where does it find the money? The newspapers were full of advertisements at the time that the Anglo-French Loan, maturing in October, 1920, was being met, inviting the public to take up War Savings Certificates. What was the object? The object was to buy bills on New York which would give the Government the right to get dollars in New York. Surely no one thinks that to get a certain amount in New York at a certain time, it is necessary to buy the whole of the bills in one transaction? Of course, they are bought up gradually. The bills represent shipments of goods to America, or other claims on America, and they are transferred to the Government in exchange for cash in London. Suppose that the Argentine Government has to pay debts in London, how can it do it? It taxes the inhabitants, and uses the proceeds to buy bills from the Argentine wheat and wool exporters, who have been sending goods to England, and have debts owing them by Englishmen 
which they can transfer to their Government, in return for cash on the spot. The Swiss have recently been borrowing from New York: how if the Americans want their interest paid in New York? American tourists pay their hotel bills by cheques, sometimes on American banks directly, sometimes on Swiss banks who reclaim the money from their American agents. If the Swiss banks get the money paid them by their Government in return for transferring to that Government the claims on New York which they could otherwise use, the matter is settled.

Is the matter any different if a railway company borrows money in London to build a railway in China? Suppose the sinking fund and interest charges amount to $£ 100,000$ a year. Silk and tea are exported to Europe, and the railway company settles its debts by buying up the bills drawn against the silk and the tea, collecting the money and transferring the money to its English shareholders.

§7. When we have thus widened the meaning of debts owing and owed to cover all claims on both sides, the only meaning which we can assign to the phrase "adverse balance of indebtedness" is that the total volume of claims outstanding during a given period of time against a country is greater than the total volume of claims in its favour. The difference between these two amounts is the "adverse balance of indebtedness," and argument would then be that the fluctuations in the rate of exchange would depend on the size of this adverse amount.

If we use the word in this - its only legitimatesense, it is not difficult to prove that the "adverse balance of indebtedness" plays a very small part in causing fluctuations in the rate. And this for this very simple reason that in the sense in which we use the term, a balance rarely exists. People in fact confuse the "adverse daily offering of bills" with an "offering of bills during a given period" and an "adverse aggre- 
gate balance during a given period" with an "adverse balance on a particular item." Let us deal with the first-named of these confusions as a preliminary. The aggregate owing and allowed on all items might be equal, and yet, if there is lack of coincidence in the rate at which bills are put on the market by the two countries concerned, there will be fluctuations in the rate. Two sets of dancers may pass each other always halfway of the length of a room, but it will not follow that they will always be moving at the same rate. Sometimes one couple, and sometimes the other, will move a little more quickly or slowly than the other, but these movements are compensated by the one couple increasing their speed whilst the other couple is slowing down, or slowing down when the other couple is increasing in speed. Applying this analogy, the bill-market from day to day will show fluctuations in the daily rate if more bills are offered than demanded, and vice versa. But such movements will be compensated, partly by speculation which we will deal with in the next chapter, partly by a fall causing increased purchases because the price has fallen, partly by a rise causing a check in demand. In this respect the bill market is like any other market in which a fall in price will stimulate purchases and a rise will check purchases, without the aggregate purchased or sold over a given period altering. What has altered is the rate at which this aggregate is bought and sold. We must next proceed to the second confusion. People very often select one item in the total balance and overlook that this item can be offset, and is offset, by some other item which they have overlooked. Thus it is usual to speak of countries such as Brazil, Argentina and (before the war) the U.S.A. as "debtor countries" because "they had an adverse balance of indebtedness." All this was intended to mean was that such countries have borrowed large sums on capital account in Europe for the building of railways, the construction of tramways and other "public utilities," the building of docks and the acquisi- 
tion of useless battleships. How was this "adverse indebtedness " liquidated ? All that happened was that, in addition to exporting enough to pay for current purchases of goods, these countries exported wheat and maize, meat and rubber in sufficient quantities to meet their instalments of debt interest as these fell due. There was no "adverse balance" at all in the sense that, taking all the items into account, during each successive period, there was not available sufficient means of payment.

§ 8. For the remainder of this chapter, we will speak of the "daily balance" and the "periodical balance" to distinguish the two cases that are usually confused with one another. The "daily balance" really causes no difficulty, in principle-though in practice the absurd mistake is often made of attempting to explain fluctuations from day to day as if these could be directly linked up with the "balance of indebtedness." This is obviously an error.

But now let us deal with the "periodical balance." Is there really such a thing in the sense that total amounts owing and owed do really differ, so that some unsettled amounts remain over? The answer to this is that such an unsettled amount can exist, although, even then, it need not affect the rate adversely, provided that the extent of this unsettled amount is roughly known. The simplest device is to postpone payment by arrangement until a more propitious time. But in this chapter we want to deal with principles, rather than with possible devices, which we will examine in the next chapter.

From the standpoint of principle, then, the answer to be made is that fluctuations in the rate due to a periodical balance are limited by increases or decreases in the volume of indebtedness occasioned by the reaction of the falling or rising rate of exchange on the balance. What is a rising (dearer) rate to one country (the debtor country) is, of course, a falling (cheaper) rate to the other (creditor country). 
The existence of such an adverse periodical balance will be marked by the trend of the rate over the period of time we are considering. There will be day to day fluctuations superimposed on this trend-but the trend measures the underlying forces, whilst the fluctuations will measure the day to day offerings and demands for bills.

Suppose, now, two countries, $A$ and $B$, with the rate of exchange falling steadily against $A$. What will be the result? We may put the matter generally by saying that, other things equal, the result of the fall in exchange will be to cause a liquidation of the balance by a more rapid transference of resources from $A$ to $B$ than would have been the case otherwise. Such a transference may take the form of encouraging imports from $\mathrm{A}$ into $\mathrm{B}$, discouraging imports into $\mathrm{A}$ from $\mathrm{B}$, and causing services and other utilities, as well as fixed property, to pass from the possession of $A$ into the possession of $\mathrm{B}$.

For, consider. Every fall in the rate of exchange will cause goods and services in $A$ to be cheaper to inhabitants of $\mathrm{B}$; whilst every fall in the rate of exchange will cause goods and services in $B$ to be dearer to inhabitants of A. It is a mistake to regard this transference of resources as being confined to exportable commodities. Persons with fixed incomes will move from $B$ to $A$, tourists will go there for holidays, and the relative cheapness of fixed property in A in terms of the money in B will cause, or may cause, factories, estates, forests, pictures, furniture, to pass into foreign hands, as such property is passing into foreign hands in Austria, Germany and Poland to-day.*

What is the effect? In general terms, the effect is to enforce economy on the inhabitants of A. They are

* See the Times Portuguese correspondent, dated November 23, $1920:-$ " There is another aspect of the situation caused by the fall in the exchange that should be carefully investigated. I refer to the opportunity which offers to invest money in Portugal, especially in the form of buying out companies, workshops, etc., or financing them." 
forced to purchase less of B's products and forced to dispense with some of their own products as well. Their demands on others are reduced, the demands of others on them are increased. If, under these circumstances, the inhabitants of such a country desire to enjoy their customary amounts of well-being, then, since a pull is being exerted from outside, the only thing to be done is to increase production; or, to quote from Thornton, who discussed this problem in 1802, the principle is that " in this country," as in all others, " the two principles of economy and exertion are always operating in proportion to the occasion for them."

When Thornton wrote, the great causes producing such "periodical adverse balances" were subsidies to the Allies, and the unexpected necessity for heavy wheat imports in consequence of a sudden deficiency in the harvest. But, as he justly pointed out, the amount which people imported from abroad or, in other words, the claims against them, bore some relation to their ability to pay nominally, because there is a limit to the amounts leaders are willing to lend as well as borrowers are willing to borrow. In other words, the original indebtedness is not indefinite, and the exchanges, in themselves, help to restore things to equilibrium.

In our day we find some analogy to the events of the Napoleonic wars in the existence of huge war-debts owing to foreign countries, heavy imports of raw materials, and so on. But it must not be concluded that these factors are the relevant ones in deciding what is wrong with the exchanges to-day, or rather that these factors of themselves would produce the present situation, were it not for other things as well. Without going too far away from our present subject, it must again be emphasised that this corrective action of the exchanges is based on the assumption that the currency is at par with gold : or, more generally, that the currency is not inflated. As soon as inflation is introduced as a factor in the problem we get complications, the consideration of which must be deferred. 
\$9. We have seen that we can go very far towards explaining why there are limits to fluctuations in rates of exchange, assuming a currency at par with gold, without assuming that gold exports take place at all. If we do take these gold exports into account what will be the result?

So long as gold can be withdrawn from bank reserves or directly out of the currency circulation, and is freely exportable, the adjustment of day to day fluctuations is a very simple matter. For as soon as the cost of meeting indebtedness by means of bill purchases rises to the point at which it is indifferent whether a bill is bought or gold is sent, some gold will be sent. Since gold was the actual basis of the world's currency before the war, gold exports were equivalent to reducing the currency of the country and increasing that of another.

Since the cost of sending gold from one place to another, though not invariable, was known and was relatively small, the fluctuations in the prices of Bills of Exchange were kept within narrow limits-within the limits set by the cost of dispatching gold in either direction. These limits were known as the "gold points." If the cost of sending gold rose, the range of fluctuation widened, if that cost fell the range of fluctuation narrowed down.

$\S 10$. We have already seen that the existence of day to day fluctuations is quite consistent with the non-existence of a true adverse balance. Consequently the question whether it was the possibility of gold exports which prevented such adverse balances from arising is an important one. The question is, is an adverse balance consistent with the possibility of gold exports? This question is quite different from the question whether, assuming that gold exports are possible, and that a true adverse balance is also possible, the range of fluctuation would still be limited by the cost of sending gold in either direction. 
This second question is simply answered. Assuming gold exports to be possible, the range of fluctuation would, in any case, be limited by the cost of gold shipments assuming that gold, in terms of the currency of the country, remains at par, or, what is the same thing, if the currency is gold or is convertible freely into gold at the Mint price. But it does not follow from this that unlimited gold shipments would be possible, because the limit to gold shipments, other things equal, depends on the volume of gold available. Consequently, if we assume that the whole available supply of gold is drained away, the exchanges might still be "unfavourable." But is this at all a justifiable assumption?

We have already seen in a previous section that an adverse balance is corrected by a transference of resources from the inhabitants of debtor to inhabitants of creditor countries. Apart from day to day fluctuations, the importance of gold shipments on a large scale, supposing them to be continued for any length of time, is that they facilitate such a transference of resources, directly and indirectly. Directly because gold itself reduces the outstanding balance, indirectly because of the effects on prices. The value of the local currency can never, so long as it is on an effective gold basis, be less than that of other currencies, also on an effective gold basis, by an amount greater than the cost of shipping gold.* But the value of the local currency in terms of goods, i.e., the local level of prices, depends on the volume of goods in relation to that local currency. If the local currency is itself gold, obviously its export will lower prices by reducing the amount of such money in relation to the goods; if it is paper money convertible into gold on demand, the condition of gold exports is similarly a reduction of the local currency. But whilst the rise or fall of the local currency in terms of other gold currency is limited, the rise or fall in the value of the local currency in terms of goods is not limited by anything except its amount and the amount of goods available. * Always assuming that there are no obstacles to exportation of gold. 
Consequently, assuming continued gold exports, prices inside the country fall-the purchasing power of money rises, and rises the more, the more gold is exported. Obviously, in the gold-importing country, the reverse state of affairs obtains, more money will mean a smaller purchasing power of money, and prices rise. But people live by goods and services and not by gold. Consequently we get exactly the same condition of things ultimately as if we assumed no gold exports; the fall in the foreign values of the local currency, which means that foreign currencies buy more of the local currencies, stimulates the transference of resources from the debtor to the creditor country. Since gold is itself a commodity, small balances are liquidated by exporting gold; the effect of continued gold exports is directly and indirectly nothing but a process of transferring resources, including the gold itself.

§11. If, therefore, there are "adverse balances" of any magnitude, their very existence creates forces which will reduce them. But the essential mistake made by those who think of the "adverse balance" as the main cause of the dislocated exchanges of to-day is to confuse cause and effect. The essential fact is not that "adverse balances" have dislocated exchanges, but that the causes which have produced dislocated exchanges have also produced "adverse balances" of greater magnitude than existed before the war. For, as has been insisted on at some length in previous sections in this chapter, "adverse balances" of any magnitude, in the only sense in which this phrase has a meaning, did not exist. The reason is simple. They did not exist because one item of indebtedness was always offset by another: and in the ultimate analysis this was due to the ability of countries to export. The formula with which we may close this section, therefore, is that provided conditions are such as to enable export, or in the more general phrase, transference of resources to take place, the "balance of trade" may be left to look after itself. 
And if we ask what is to be done to allow export or other transferences to take place, the answer is-a price-level which will make it to the interest of foreign countries to purchase.

$\S 12$. We will have to investigate the bearing of this point-the fundamental one in the "restoration" of the exchanges of to-day-at considerable length when we come to discuss the present position of Europe. Immediately, another set of considerations must claim our attention.

Gold exports, in a country using a gold currency, are not welcomed since they necessarily influence the policies of central banks, which are responsible for the maintenance of sound monetary conditions. Fluctuations in the values of currency, further, provide opportunities for speculative profits. We must consequently investigate the pre-war methods of regulating the exchanges and link these up with general principles which we have so far been discussing. This investigation will form the subjectmatter of the next chapter.

\section{CHAPTER IV.}

\section{PRE-WAR METHODS OF REGULATING THE EXCHANGES.}

$\S 1$. In investigating the pre-war methods by which the exchanges were regulated, it is necessary to distinguish between the technical details by which the result was attained, and the reasons why the results attained were successful. This distinction is the more important, as at the present time all sorts of solutions are being proposed, without due attention being paid to the conditions under which such solutions are likely to be successful.

From the standpoint of the actual methods adopted, we must remember that to a large extent before the war, the 
great commercial nations of the world were on a gold basis, so that practically they were using the same currency. This meant that all the local currencies were closely linked together. Even those countries which were not directly on a gold basis could, by the adoption of what is known as the "gold-exchange standard," act as if they were on an actual gold basis. We shall have occasion to say a good deal more about the gold-exchange standard in later sections of this chapter. Let us first investigate exchange regulation on the assumption that we are dealing only with gold-using countries.

\$2. We have already seen that we ought to differentiate two groups of movements in the rate of exchange-the day to day fluctuations and those which rest upon an underlying movement in the relations of indebtedness. So far as the latter movements are concerned, we must recognise that their magnitude was not great, but in so far as the exchanges of a particular gold-using country tended to be unfavourable for relatively long periods of time, such adverse conditions of indebtedness were indicated. In other words, we must deal with surface movements and with the total movements as distinct phenomena.

§3. The first of the regulatory influences was constituted by what have become known as "Arbitrage Operations." The effect of such operations is to reduce inequalities in the rates obtaining at the same time at two or more centres, that is, arbitrage acts as an equalising influence. From the standpoint of the arbitrage operator, the object of the operations is to make a profit out of the existence of these differences.

"Arbitrage operations" are among those economic operations which are very much easier to illustrate than they are to explain. Let us begin with an illustration from an allied field. Suppose that the price of Canadian Pacific shares is higher in New York than in London. 
We will eliminate the difference in the possible value of money by assuming that the rate of exchange remains constant for the time being. What we mean by saying that the shares are dearer in New York is that, to a holder of shares, money in New York is cheaper than it is in London, for with one share he can buy more money than he could in London. In London, on the other hand, shares are cheap, that is to say the holder of money finds that with a smaller amount of money than he would have required in New York he can buy the shares. Obviously, if anyone can buy shares in London, and sell shares in New York, he will make a profit from the transaction. What has he really done, however? He transfers shares from the place where they are cheaper to the place where they are dearer, and he has transferred money from the place where it was cheaper to the place where it is dearer, where, in other words, it can buy a larger number of things. The effect of this transfer is to make shares cheaper in New York, and money cheaper in London, and thus the general exchange ratio between money and Canadian Pacific shares becomes more equal, shares falling in value in one place, and money falling in value in the other.

Now suppose that on a particular morning the rush of buyers of francs in London is such that the rate of exchange for telegraphic transfers is $£ 1=25.25$ francs. At the same time in Paris there will be a certain number of people who will have to make payments in England. Of course, the final rate which will be established on that day will depend on the relative indebtedness falling due on that day, so that if we knew all the facts we could say that the general relations between supply and demand for francs and pounds will be so-and-so. But just as there may be different prices at two stalls in the market place until every seller and every buyer knows what is going all around him, so there may be differences in the rate at particular moments in London and Paris for the same articles. 
Suppose that at 11 a.m. the telephone bell rings in a London bank, and the exchange expert is informed by a similar expert in Paris that pounds are selling for 25.35 francs. Suppose that the higgling of the market has established the rate at $\mathbf{2 5 . 2 5}$ in London. That is, the eagerness of buyers in London has forced up the rate in London, and the eagerness of buyers in Paris has forced up the rate for pounds. But francs are for the moment costing more to the holder of pounds in London than they would if he bought them in Paris, and pounds are costing more to the holder of francs if he buys them in Paris than if he bought them in London. For, if the holder of pounds bought francs in Paris, he would get 10 cents per $£ 1$ more than he is getting in London, and pounds are costing 10 cents more in Paris than the cost if bought in London. This is quite a different thing from saying that francs in either centre are cheap or dear, as the case may be, because we are here confronted with a same thing costing different things in the two centres.

What is to be done? Suppose that the difference goes on existing until people get to know of it. Then suppose that a man has $£ 1,000$ available in London. He can sell that $£ 1,000$ in London for 25,350 francs in Paris. He will then be able to get his thousand pounds back again, by selling in London 25,250 francs, which will bring him in $£ 1,000$. But in addition to getting his $£ 1,000$ back again, he will make a profit of 100 francs. If a large number of people do this, it is obvious that more pounds will be selling in Paris, so that their value in Paris will fall, and more francs will be selling in London, so that the value of francs in London will fall also. But a fall in the value of francs in London means that the $£ 1$ will buy more of them, and a fall in the value of pounds in Paris means that $£ 1$ can be bought with a smaller number of francs. In effect pounds are placed at the disposal of Paris until pounds will not buy more francs in Paris than they will in London, and francs will be placed at the disposal of London, until 
the fall in the value of francs in London means that they will not buy more pounds in London than they will in Paris. This is no stranger than the fact that, if shares are worth more in New York than they are in London, shares are placed at the disposal of New York and money is placed at the disposal of London until money and shares exchange for as much (or as little) in the one centre as in the other.

Our profiteer appears as a seller of pounds in Paris, and as a seller of francs in London: that is, in both centres he sells the foreign currency. What does this really mean? It means that, so far as the general relations between supply and demand between francs and pounds are concerned, the ratio is unchanged, for he adds the same amount to both sides of the account. What he has done is to add these amounts in each case on the temporarily more expensive market. On the whole, Paris may be indebted to London, or London to Paris. Inside the general limits as thus set he is preventing local differences in the price.

If the operator is selling a small amount in the two centres relatively to the totals bought and sold there, there is hardly any risk attached to his action. But he has to be taking into account the risk that if he sells too much the market may be adversely affected. Consequently, the ideal practical arrangement is the utmost simultaneity in the two sales, and this is where our exchange experts come in. They will sell on one another, and meet the bill of the other out of the proceeds of their sale. A, the London expert, sells 25,250 francs on B : $B$ sells $£ 1,000$ on $A$. A gets in $£ 1,000$ and uses it to meet the cable which $B$ has sold for 25,350 francs. He will have to pay away 25,250 to meet A's cable, which leaves them with 100 francs profit.

I have taken a difference of 10 cents. in the rate, which is far too wide to correspond to realities. Much smaller differences were sufficient to cause these compensatory sales before the war. My object was to avoid confusing the reader with small amounts, 
$\S 4$. The technical term arbitrage is confined to the type of operation we have just been dealing with: whether those operations are concerned with two or three or four centres is immaterial to us. Their economic effect is to prevent local differences in the rate. But we might have dealt with a case almost exactly similar in principle, though it concerns not local differences in the same rate, but differences in the same place as between two different rates. Let us take the following case. Suppose that in New York the rate for sight bills is $\$ 4.80$, and that the rate of interest in London is 4 per cent. This means that the rate for 90 days bills ought to be, in New York, at the same time, $\$ 4.80$, minus discount for three months at 4 per cent., which is the same thing as saying that we must deduct 1 per cent. from the sight rate. This gives us a long rate of $\$ 4.75$ approximately. Now suppose that on a particular day, whilst the sight rate remains unaltered, the long rate suddenly goes to $\$ 4.79$. This means that, relatively to the sight rate, the long rate has become expensive, so that it pays to sell it. Suppose that a man with a long bill sells it, and uses the proceeds to buy the cheaper article, the sight rate. If, subsequently, the long rate falls again, and the sight rate rises, he will sell the sight, buy the long, and make a profit out of the transaction. To use the expressive technical term, he has been "straddling." "Yes, but why didn't he just sell the long bill and then buy it back again when it became cheaper?" some reader may ask. As a matter of fact he could have done this, and might have become a "bear"* speculator. But his risk in this case is really greater. Suppose the price had gone still higher, he could not have bought back at a profit. But if he is straddling it makes no difference whether the price goes higher still, provided that the margin between the two rates becomes narrower than it was when he speculated. For, suppose that the long rate rises permanently because

* That is, he sells, hoping to be able to buy in again at a lower price. 
news not generally known at the time it did rise originally justifies the rise, say, a failure of the crop, which means that there will be less to export, so that bills on London acquire a scarcity value. This will mean that the sight rate will rise too, but provided that it rises to a point which will restore the margin justified by the current interest rate in London, our speculator will still emerge with a profit. For, in that case, though he will make no profit in rebuying the long bills which he sold, he will still be able to resell the sight bill which he bought, at a profit.

§5. Taking advantage of temporary differences in price, then, steadies the rate. But we must now turn to what is usually considered to be speculation, and which most people regard also as so reprehensible that in some countries severe penalties are now imposed on persons who speculate in foreign exchange.

Anyone taking up the Economist or any other financial paper will notice that banks advertise that they are prepared to deal in "Forward Exchange." What does this mean? It means this. A business man having to make payments to the United States can walk into a bank and ask to be supplied now with the price of dollars in six weeks' time. If he accepts, he buys forward, and the bank sells forward: that is, the bank engages to provide him with currency of the kind he desires at a fixed price. Or, a business man has been selling goods to France, and is nervous about the exchange, so that he wants a firm price basis. Again, the bank comes to his assistance, and buys forward, whilst the business man sells forward. Such transactions are obviously a matter of great convenience to business men, but they mean that for part of the time, at any rate, the bank is speculating. If it sells forward without having the bill in hand, or buys without having a customer ready to buy the bill from it, the bank is speculating on being able to fulfil its engagement with profit to itself, on being able, in other words, to "cover" satisfactorily. 
Now let us follow out the consequences of such forward buying and selling. The effect is to even out the prices of bills. For, suppose that no such forward purchasing took place, and that a sudden concentration of demand occurred. The result would be a rapid uprush of the rate from the relatively low to the relatively high level. But since the bank has sold forward, it will cover by forward purchasing as much as possible, so that both buying and selling is spread over a longer time, and as a consequence the price tends to be steadier; instead of all the bills required being all bought suddenly, their purchase is arranged for in anticipation of the time when they will be actually wanted. Instead of all the bills being all thrown on the market simultaneously they are gradually disposed of, so that the price is not unduly depressed at any one moment.

The speculator need not, of course, be a bank: speculation in exchange rates may be carried on by anyone who is prepared to risk his money on it. At the moment, for instance, huge amounts of German marks, Polish marks, Italian lire and the rest are being held for a rise by speculators, a fact which occasions much dissatisfaction, though I cannot bring myself to believe that the effects of speculation are even now as bad as some persons think. The present situation will, however, be examined later : in this chapter we are dealing with pre-war conditions.

$\S 6$. Such speculative operations as we have examined so far are perfectly consistent with regulatory operations which deal not with surface movements, but with the tidal movement in the exchange rate. When we deal with these, we are dealing with changes produced by alterations in the periodical balance.

Here the first point to be dealt with is the influence of the creation of "finance bills." Finance bills are a class of bills for which no exact definition seems to exist, but the function they fulfil is clear enough.*

* For a discussion see Whitaker, Foreign Exchange, pp. 359, 380; Spalding, op. cit. 
We may define a finance bill as a time bill, other than one arising from a commercial transaction drawn by one banker on another, by which funds are placed at the disposal of a given centre for a certain period of time. Now let us see how they help to solve the problem of periodical changes in rate.

It is a well-known fact that in the autumn of every year the exchange between this country and America tends to move against this country and in favour of the United States. At that time of the year, consequently, an American firm can always cover its engagements to this country cheaply. Consequently, if an arrangement is made whereby banks and finance houses are given command over the resources of London for a period of time which matures in August, or later in the autumn, such a contract can be easily liquidated. Suppose, now, that an American bank finds that its resources are being strained, and that it desires to borrow in London. By drawing a bill on London by arrangement with an English bank, it can by this means get the money it wants. A bill is drawn on the first of June for 90 days, which means that it must be paid on September 11 at latest.* The bill is drawn and sold in America to an importer of English goods, sent by him to the English exporter and by him discounted or held to maturity, or is sent to London and discounted here, the bank selling cable transfers in New York against it. Suppose the bill is for $£ 10,000$. That means that in September the bank in London, on which the bill is drawn, takes the risk that if by the due date it has not received the $£ 10,000$ which it has promised to pay by accepting the bill, it must meet the bill out of its own resources. The American bank, by discounting the bill here, virtually pays interest on the money, because it only gets the present value, and has in addition to pay a commission to the London acceptor.* As the end of the period

* Allowing seven days for the bill to reach London and assuming acceptance on the day of arrival. 
comes along, sight rates on London fall as the grain and cotton bills accumulate, and the American borrower buys a sight bill for $£ 10,000$ to send to its London correspondent.

Now what does all this come to in terms of the exchanges? When the bill is originally sold in America, before or after discount, the American bill market has more pounds at its disposal, and the rate drops. At the end of the period, when the bill has to be met, then the American market has more demands for bills than it would otherwise have had, so that the rate does not fall to the same extent. That is the first and most obvious result.

The second result is that, from the standpoint of the United Kingdom, the burden of meeting the indebtedness arising from the imports is offset by the credit arising from the maturing finance debt.

Finance bills therefore represent a means of meeting indebtedness. A centre which has at its command balances maturing steadily at times when its obligations on account of the movement of goods inwards are turning the exchanges against it is in a favourable position.

Now an American bank is not likely to borrow in London in this way unless the interest cost to it is less than the profit it is likely to make from the use of the funds. Consequently, a low rate of interest in London is likely to stimulate the investment of floating sums in America and other places by means of the discounting here of American-held London acceptances. Now, let us look at it from the other angle.

Suppose that the rate of interest rises here. What effect has this on the economics of finance bill operations ? It now becomes much less desirable to borrow in London, because the cost rises. On the other hand, it becomes desirable to invest in London, because the cost of buying

* This charge is of course absolutely the same, but proportionately heavier, the shorter the currency of the bill. 
bills falls. Every rise in the rate of interest makes the present purchase of a London bill more desirable. From the standpoint of the exchanges this works out as follows. The higher the rate of interest, the lower the long rate in America and other places will be, and the cheaper the purchase of a bill on London, the less remunerative the sale of such bills. Consequently, finance bills will not be offered in New York, or discounted in London, because of the smallness of the return; on the contrary, what will happen will be that there will arise a demand for bills on or in London, since these are cheap, for anyone who is willing to part with dollars in order to get pounds. The drawers of finance bills want to sell pounds in order to get dollars. If there are firms who are willing to accept English-drawn bills in New York, these will sell at a good price in London, simply because the less dollars the pound is worth at a given moment, the more valuable dollars are to sell in London.

We can now see why it is that, when the rate of exchange is unfavourable to London, the City should expect the "bank rate to go up." The object directly is to cause loans to foreign countries to be drawn in, in order to take advantage of the higher money rates prevalent in London, and to cause further investment in London, owing to the cheapness with which this can be done. But surely this is equivalent to increasing the funds at the disposal of London? The pressure due to the adverse state of the exchanges is met by the temporary investment of funds in London. From the wider point of view, instead of taking the whole of what is owed out of London, some of it is kept here in order to take advantage of the higher rates for money. Or, if the reader prefers to have the matter put in a rather different way, which comes to the same thing, when rates are unfavourable to London, owing to the pressure for means of remittance abroad, the rise in the bank rate creates a new demand from abroad which fills the gap in the "balance."

But we have not finished with the effects of the rise on the bank rate. It is a well-known fact that the price 
of securities tends to fluctuate with the rate of interest, because much of the purchase of securities is done with borrowed money, and this becomes more and more costly as the cost of borrowed money rises. Hence, periods of high interest rates cause securities to sag in price, and the natural result is that they become cheaper to buy here. This, again, creates a new demand for money in London, and again affects the rate of exchange.

It is also a well-known fact that a rise in the bank rate tends to check the holding of goods for speculative purposes, and, by increasing the cost of borrowing from the banks, to decrease the tendency for business men to borrow. That is, the immediate effect is to check the expansion of industry, and to cause prices to fall. The effect is again to cause a greater amount to be bought from the country than would otherwise be the case, in other words, to alter the components of the balance in such a way as to bring the exchanges to par again.

Apart from the speculative movements which must be treated by themselves as affecting primarily divergencies in the day to day movements in rates, we can sum up the results so far attained as follows. The two main methods of regulating the exchanges are the temporary transference of sums from one country to another, so that the sums are always flowing in the contrary direction to the movement in the exchanges, a movement resting partly on self-interest and partly on deliberate intervention of the central banks, and second, the exertion of pressure on the price level so as to induce purchases of securities and goods by foreigners.

The reader will now also see why I said in my first chapter that it was possible to exaggerate the degree to which gold exports actually were necessary. They were unnecessary before the war, because of notning more mysterious than the efforts made to prevent their becoming necessary.

The reader will also see that the condition for a successful use of the instrument of the bank rate is such a condition of affairs in the monetary world, that a 
rise in the bank rate will mean an effective fall in the price level. It is only on this condition that more will be purchased from the country, and unless this happens, the rates of exchange will not be corrected, though it may be the case that the movements in the excliange connected with finance bill operations are, in themselves, sufficient to cause the rates to be restored to parity, without the higher bank rate having to be exerted for a sufficiently long period of time to cause the price level of goods in general to be much affected.

§ 7. We now come to the gold exchange standardthe enormous importance of which in the modern world was first prominently brought into light by Mr. J. M. Keynes in the now almost classical second chapter of his Indian Currency and Finance (1913). The object of the gold exchange standard is the maintenance at par with gold of a local currency not itself gold or not itself on an effective gold basis, so far as the internal currency is concerned. Mr. Keynes himself believes that the system contains " one essential element . . . in the ideal currency of the future." If one asks what this essential element is, the answer made is just the opportunity which the gold exchange standard affords of relating a non-gold currency effectively to gold, so that a given number of the units of the local currency shall always be really and effectively convertible into the number of gold units which the law states these units are to be worth. How can this be done?

The principle is quite simple. The value of a currency in terms of gold depends on its quantity. If the currency is itself gold, there is no problem, so long as the law allows melting and export. For, in that case, if the value of the gold as gold bullion is greater than the value of gold as currency, the immediate effect will be that the gold coin is melted down and exported. If the gold as currency is worth more than the gold as bullion, there will be more coin turned out by the Mint : so that to maintain an exact equivalence between the 
value of gold as bullion and gold as coin, there must also be free and open mintage ; that is, the Mint must be prepared to turn bullion into coin in unlimited quantities and free of charge to the consumer. If the Mint charges for turning gold bullion into coin, then the value of the coin will exceed the value of the bullion out of which it is made by the cost of mintage only, provided that unlimited quantities of bullion can be taken to the Mint.

Now this direct relation of gold as bullion and gold as coin cannot, of course, be established in the case of countries which do not allow melting of coin and its export, or which do not mint freely, or which do not possess a gold currency at all in practice, or which do not pretend to have a gold currency, but have a silver currency. What can be done in these cases to maintain a stable relation between gold, the international standard of value and the local currency? What is wanted is a system which will reduce the quantity of the local currency as soon as this shows signs of becoming redundant.

On the other hand, if the local currency shows signs of becoming appreciated in terms of gold, if, that is, it exchanges for more than the amount of gold which it is nominally worth, what is obviously wanted is an increase in the local currency. Hence the system works by locking up the local currency when it is redundant, and increasing it when it is scarce.

Now let us see how the system works in practice before we ask under what conditions it is likely to be successful or the reverse.

The Indian currency was, until recently, on a gold exchange standard basis. The Indian currency consisted predominantly of silver rupees, with a face value greater than their intrinsic bullion content, that is, the silver in a rupee would not have sold for an amount of gold equal to the amount of gold that a silver rupee actual ly exchanged for. The gold value of a rupee was, before the war, nominally one shilling and fourpence, 
that is, 15 rupees went to the pound sterling of 113 grains of gold. How was the value maintained ?

The answer is that the Government of India was prepared in practice, though it denied liability in theory, to buy and sell rupees at prices which practically kept the value of rupees within very narrow limits in terms of gold. The gold it offered was gold in London, the silver rupees it offered were located in India.

" The Secretary of State for India, who had long been the largest seller of remittances on India, undertook to sell Bills of Exchange on India without limit of amount at 1s. $4 \frac{1}{8} \mathrm{~d}$. per rupee as a maximum rate. $\mathrm{He}$ also maintained, though without formal notification, the practice of not selling below 1s. $329-32 \mathrm{~d}$. per rupee . . . occasionally, owing to temporary variations in the currents of trade, there was a greater demand for homeward than for outward remittance. This might have caused the rate of exchange to fall for the time considerably below the minimum rate of 1 s. $329-33 \mathrm{~d}$. per rupee mentioned. ... On the few occasions on which such a demand arose, the Secretary of State met it by selling homeward remittances (commonly known as reverse drafts) at a fixed rate slightly below the minimum just mentioned." Thus Sir Lionel Abrahams before the Indian Currency Commission of 1919.*

So long as the Indian Government was willing to sell exchange on India at prices which varied only between four thirty-seconds above the fixed ratio and three thirty-seconds below it, it is obvious that no one would buy exchange above this rate. But by selling in this way, the Indian Government bought gold in London, or cheques on London banks which were convertible into gold at sight, and paid out rupees in India. If people wanted gold in London, the Indian Government gave it to them by selling reverse bills, thus locking up rupees in India and releasing gold in London. Now it happened in practice to be the case that India exported so much that it normally wanted not gold in London, but rupees or

* Comd. 528, Vol. 2, p. 2. 
gold in India, and there was as a matter of fact a heavy export of gold to Inaia. But this did not prevent the possibility of fixing the rate of exchange at these limits, only in this case, so long as what people wanted was money in India, it prevented rupees rising above the maximum price of the council rates fixed by the Indian Government.

This system worked so easily before the war that people rather took it for granted, and not sufficient attention was paid to the underlying conditions which made it possible. Now the war had made the system unworkable for the time being, and the reasons therefore are worth a moment's close attention.

Suppose that silver suddenly rises very much in value in terms of gold : that is, a silver rupee was worth more as bullion, so that it pays to melt rupees, export them, and sell them for gold as bullion. What is the natural effect? People will buy rupees at their old gold ratio of $1 \mathrm{~s}$. $4 \mathrm{~d}$. a rupee, melt them down, sell them as silver bullion, at the expense of the Indian Government, and come out with a handsome profit. If I can buy for 1s. 4 d. what I can sell for 2 s., say, then I must obviously make a profit of Sd., minus expenses, so long as the seller will sell at the fixed rate. Consequently, if the local currency rises suddenly in value, *the only thing to do is to alter the ratio between it and gold, for otherwise the local currency will disappear, if it is exportable at all, as silver certainly is. Or the Government must ration the amount it is prepared to sell, or it must reduce the amount of silver in the local currency, or prohibit its export. $\dagger$ The first difficulty, then, during the war, was the rise in the silver value of the rupee. Now, it must have struck the reader that, though there is not much difficulty in increasing the local currency, supposing it to

* In this case it rises in value as a purchaser of silver bullion; for though it gets only the same amount of bullion as before, the bullion is more valuable.

$\dagger$ For the complete history of the Indian Exchange during the war, the volumes of the Royal Commission of 1919 should be consulted. See especially. Cd. 529, of 1920, Appendix I. 
be worth less as the material out of which it is made than as money, there may be very considerable difficulty in increasing the amount of gold at the disposal of the Government if the reverse demand should become very heavy. If, for instance, the amount of currency is not limited at the time when the demand for outward remittances is great, then insufficient currency is locked up, and the value of the local currency will go on falling. And the more it falls, the greater the difficulties of the Government will become. For, if it goes on giving people more gold at fixed rates, the more people will demand. As the local currency falls in value the less gold it will command in the local market, the gold, that is, which is dealt in as a commodity. If the Government gives a fixed gold price in return for rupees, obviously it will pay to buy reverse exchange, change it for gold, import the gold, and make a profit at the expense of the Government, which is virtually giving the buyer so much gold for nothing. Here we have some of the difficulties of the Indian situation: but here we have also the difficulties of any gold exchange standard system if it is worked without an intelligent appreciation of the underlying difficulties.

§8. It is desirable at this stage to generalise the conditions under which the gold exchange standard, in the sense of a system of maintaining a fixed par between the local and the world currency, is no longer effective.

(1) First comes the possibility that the balances upon which the regulatory authority depends are exhausted and yet an unsatisfied demand for world currency may go on existing.

Now when is this state of affairs likely to obtain ? It obtains, using the language of the believers in the balance of trade theory, when exports decline and imports increase. But this will only happen if the local ${ }_{\text {sa }}$ price level rises so that it no longer pays to buy there, and so export demand falls off, whilst the lower 
price level outside the area and the higher price level inside the area stimulate sales to that area.

Now we have already seen that the essential idea of the Gold Exchange Standard is to lock up the local currency. This locking up normally tends to decrease its amount, and this reduction in amount raises its value, that is, reduces prices. But if, whilst money is thus being locked up and world currency is being released from the reserves, the local government nevertheless goes on issuing new currency simultaneously, in amounts sufficient or more than sufficient to fill up the gap thus caused in the volume of local currency, prices will not fall; exports will diminish and the only thing left to do is to alter the ratio of the local currency to the world currency so that the latter becomes dearer. This is the same thing as saying that the price at which world currency will be sold by the government or other regulatory authority will be such that the official exchange minimum will be lowered. In this way the value of the local currency is made to correspond to the higher level of prices in the local area, the price of imports will rise to the local importers, and the cost of exports to the world buyer will fall, because he is buying the local produce at a price lower than it was before the price of the local currency had fallen in terms of world currency.

(2) The converse case is the one where the reservoir, into which the world currency pours, whilst the local currency is released in exchange, fills rapidly, so that the difficulty is not that of finding enough world currency, but of providing enough local currency. Suppose that this local currency is limited in amount, a time must come when the issuing authority is left with no more of the local currency to offer. Again employing the language of the balance of trade theorists, when is this condition of affairs likely to obtain? When exports are stimulated and imports are checked: and this condition of affairs again occurs if the price level inside the area is lower than the price level outside the 
area, because this encourages exports and checks imports.

Now the usual solution of this state of affairs is that gold flows into the country, prices rise, and exports are checked, or, in the case of a silver currency, that silver is bought with the gold; or, in the case of a pure paper currency, that credit paper is issued against gold in a foreign centre. In the same way, the mere fact that exports increase raises the price of the exportable articles, so that the conditions for equilibrium are present. But suppose that the Government of the country deliberately pursues a policy of keeping the local price low, so that it deliberately restricts the import of gold-what is the solution? The only immediate solution available is to alter the ratio, for by this means it becomes to the disadvantage to buy in the country in terms of world currency, whilst the fact that world currency has now become cheaper stimulates purchases from abroad.

The desirability of thus creating a high exchange ratio in the interests of the local (low) price level was raised at the Indian Currency Commission of 1919, and found an advocate in Mr. J. M. Keynes, who suggested that the price of the rupee in terms of gold or sterling should be fixed high, expressly on the ground that it was undesirable that Indian prices should be allowed to rise to the level of world prices.*

*Cnd. 528, question $2635 \mathrm{et}$. seq. We may look at the question raised in the text in a slightly different way as follows. Suppose that the original ratio is left unaltered; that world prices outside the area rise and that the imports fall off whilst the exports increase sharply. Suppose further, that the government of the area desires to avoid a rise in prices and forbids the import of gold. Now the rise in the export volume is itself the result of lower domestic prices. If the ratio remains unchanged, this means that whilst foreigners can continue to buy cheaply, because the value of their currency in terms of the local currency is as great as it was, the purchasing power of the local currency is reduced in the outside area ; because prices are higher there, and the local currency exchanges for no more in terms of world currency than it did before. Relatively to prices outside the area, the world currency is overvalued by the fixed ratio, whilst, again owing to the fixed ratio, ontside the area the local currency is undervalued. Since the regulatory authority itself desires to avoid 
To sum up the gold-exchange ratio, it is of the utmost importance for the effective working of the system that, if and when this system is introduced into a country that (1) the choice original of ratio should be such that when the world currency is converted into the local currency, prices are, to the holder of world currency, not greatly different to those outside; (2) that prices inside the area and outside the area should throughout the period of maintenance of a given ratio not differ by more than relatively small amounts, which produce self-regulatory effects. In particular, price policies which keep the internal price level below the world level, and currency policies which produce price levels above the world level will, if persisted in, mean that the ratios originally chosen cannot be maintained.

The final conclusion which emerges is again that of Chapter III. Provided that the price level is properly attended to, there is no need to worry about the balance of trade. This can be left to look after itself.

a rise in prices inside the area, the only remedy is to alter the ratio, because this increases the cost of buying from the area, checks exports, prevents prices inside the area from rising, and at the same time brings the external and the internal value of its local currency more in correspondence. For, since this local currency buys more than the world currency does, its value in terms of the world currency before the change was too low.

It is not generally recognised that when the internal price level is lower than the world level, the adjustment comes by a rise in prices due to the fall in the value of the local currency in terms of goods : this fall being produced by a falling off in the volume of goods and an increase in the volume of money, in consequence of gold imports. The majority of people are still under the impression that gold imports are necessarily a good thing, and therefore do not recognise that in effect these increased gold imports effect equilibrium by reducing the value of money, that is, bring the local price level to the world level. But the rise in price in America ought to convince people that there may be too much gold in a country in relation to goods, whilst the attempt of Sweden to keep down prices by refusing gold shows that at least one government was wise enough to prefer goods to gold.

Of course, in the days before the war, the movement both of gold and goods was so free that the very small differences between the inflow of goods and the outflow of goods very soon produced their own cure. 
BILLS AND TELEGRAPHIC TRANSFERS DRAWN ON INDIA

BY tHE SECRETARY OP StATE.*

\begin{tabular}{|c|c|c|c|c|c|c|c|c|}
\hline \multirow[b]{2}{*}{ Year. } & \multirow{2}{*}{$\begin{array}{c}\text { Amount } \\
\text { in } \\
\text { Rupees. }\end{array}$} & \multirow{2}{*}{$\begin{array}{c}\text { In } f \text { stg. } \\
\text { at } 1 / 4 \\
\text { per } R .\end{array}$} & \multirow{2}{*}{$\begin{array}{c}\text { Actually } \\
\text { Paid in } \\
£ \text { stg. }\end{array}$} & \multirow{2}{*}{$\begin{array}{l}\text { Gain } \\
\text { or } \\
\text { Loss. }\end{array}$} & \multicolumn{3}{|c|}{ Rate per Rupee. } & \multirow{2}{*}{$\begin{array}{l}\text { Spread } \\
\text { between } \\
\text { Highest } \\
\text { 3 Lowest }\end{array}$} \\
\hline & & & & & & Lowest. & a & \\
\hline $399-1900$ & & & & $\begin{array}{r}E \\
+80\end{array}$ & & & & \\
\hline $00-1901$ & & & & -22 & & & & \\
\hline 02 & 278 & 18.553 & 18. & $-14,332$ & 5 & 875 & & .2 \\
\hline 03 & 67 & 98 & & $+2,129$ & & 375 & & .2 \\
\hline 04 & & 36 & & $+72,980$ & & & & \\
\hline 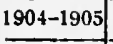 & 3 & 77 & 6 & $+68,400$ & & 39 & & \\
\hline 6 & 4 & 3 & 31.567 & $+84,089$ & & & & \\
\hline 77 & 4 & 3 & 3 & +17 & 16.187 & 15.969 & & \\
\hline 08 & 2 & 9 & & $+27,718$ & & & & \\
\hline 09 & 2 & 3 & & $-60,38$ & & & & \\
\hline & 4 & & & $+69,075$ & & & & \\
\hline & & & & +9 & & & & \\
\hline 1911-1912 & 403.771 & 26.918 & 27.059 & & & 15.937 & & .219 \\
\hline 912-1913 & 384.988 & 25.666 & 25.760 & $+93,827$ & 16.1 & 15.969 & 58 & .187 \\
\hline 13-1914 & 465.969 & 01.000 & 31.201 & $+136,246$ & 10.150 & 15.937 & 16.070 & .219 \\
\hline 14-1915 & 116. & 1.740 & 1.140 & $+2,219$ & & & & . \\
\hline 16 & 3 & 3 & - & $+110,685$ & & 37 & 10 & 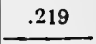 \\
\hline $1916-1917$ & 490.434 & 32.696 & 32.998 & $+302,471$ & 0 & 31 & & .469 \\
\hline
\end{tabular}

\section{CHAPTER V.}

\section{THE FOREIGN EXCHANGES DURING THE WAR.}

$\S 1$. In the Statistical Appendix to this book will be found a history of the foreign exchanges as illustrated by the movements in the New York and the Swiss Exchange Markets. It will be noted that the record is, with few exceptions, one of collapse so far as the European belligerents are concerned. The exceptions are the London-New York and the Paris-New York rates, and, coinciding therewith, the London-Paris rate. On the

- Statistical Abstract relating to British India, Cmd. 335, p. 83. 
other hand, the neutral rates have risen violently, as has the exchange with silver-using countries, looking at the matter from the standpoint of New York, and a fortiori, therefore, from the standpoint of the European belligerents.

In order to complete the record, I append (p. 67) the principal movements in the London Exchange Market during the war and in recent months, taken from Barclays Bank Circular for January, 1921.

$\S 2$. This almost general failure of the rates of exchange even to remain at or near the theoretical par of exchange is the remarkable fact with which the remainder of this book is primarily concerned. The interest of the problem is the greater when one remembers that for the greater part of the period, 1914-1920, European Governments have been resorting to expedients designed to prevent this enormous decline in the external value of their currencies. In this chapter I shall be concerned in pointing out the nature of these alleviative devices; in the next chapter I shall try to show why, for the greater part, these devices were completely unsuccessful. This chapter, therefore, will be mainly descriptive; the next will be mainly critical.

$\S 3$. Let us first note certain matters which are of the greatest consequence when we come to the critical portion of our work.

(a) The period of the war has been marked by a very great rise of prices, accompanied by an equally great increase in the circulating medium. Moreover, this increase in the circulating medium has been predominantly, so far as the belligerent European nations are concerned, of inconvertible paper money. Even where this paper money is convertible into gold coin, such gold coin cannot be melted down, or exported without the permission of the Governmental authorities. In other European countries, not directly engaged in the war, 


\begin{tabular}{|c|c|c|}
\hline \multicolumn{2}{|c|}{ 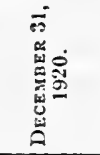 } & 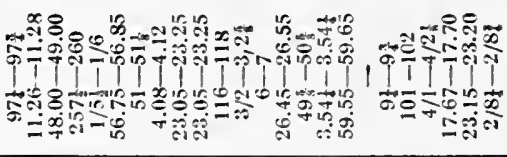 \\
\hline \multicolumn{2}{|c|}{ 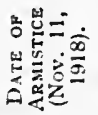 } & 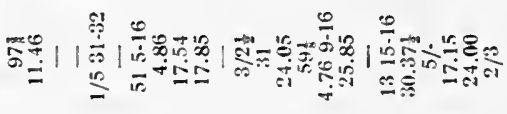 \\
\hline \multirow{2}{*}{ 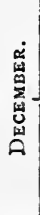 } & 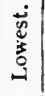 & 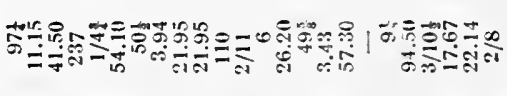 \\
\hline & 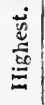 & 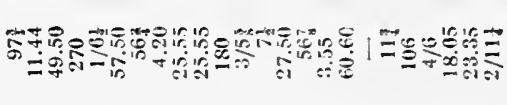 \\
\hline \multirow{2}{*}{ 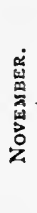 } & 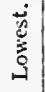 & 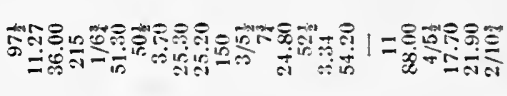 \\
\hline & 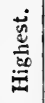 & 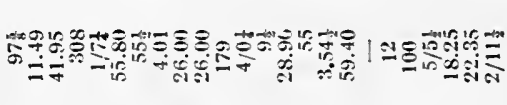 \\
\hline \multirow{2}{*}{ 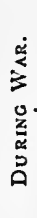 } & 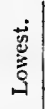 & 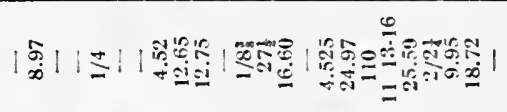 \\
\hline & 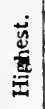 & 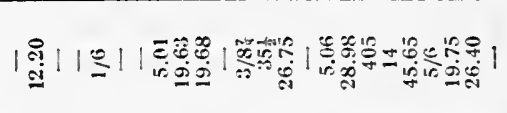 \\
\hline \multirow{2}{*}{\multicolumn{2}{|c|}{ 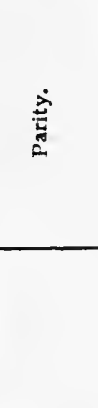 }} & 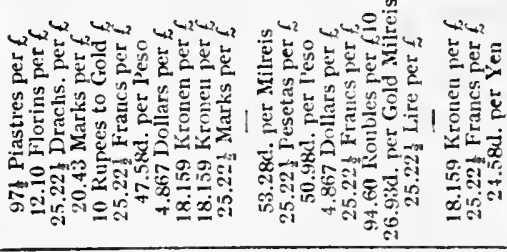 \\
\hline & & 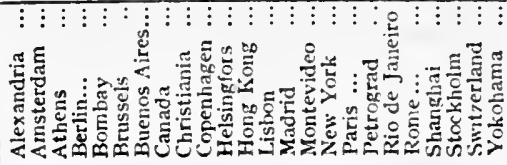 \\
\hline
\end{tabular}


there has also been in most cases an appreciable increase in the note circulation; though in these cases, the increase has been accompanied by a very considerable increase in the local gold holdings. In the United States the same phenomenon is to be noted. The result has been that the rise of prices, in so far as this is to be associated with the increase in the means of payment, has not been confined to the direct European belligerents, but has spread over the whole of the world. Not only has the purchasing power of money in the belligerent, paper-money using countries, fallen enormously, but the purchasing power of gold has fallen all over the world.

(b) The next fact to be noted is that the productive capacity of certain of the belligerent nations has fallen very much. In other words, not only has the purchasing power of the world, in terms of money, expanded enormously, but the supplies of goods and services, for which this purchasing power is expended, have fallen off also, though not to anything like the extent that the quantity of money has increased.

(c) It is the increase in the quantity of money, and the price-revolution which this increase has brought with it, that is the main cause of the present dislocation of the foreign exchanges, in my opinion. But to justify this opinion at this stage is to anticipate the work of the next chapter; and it is really much more enlightening to investigate the methods of exchange control actually adopted during and after the war, and to note that the majority of these failed, simply because they overlooked the fact that the increase in the quantity of money has altered, not the fundamental laws of economics, which are, indeed, completely confirmed by what has been happening during and since the war, but the efficacy of traditional solutions of the problem; and this, because these solutions were 
based in the main on the assumption, though that assumption was never clearly realised, that free movement of gold would bring the price levels in all countries so nearly to a common level, that the attention of statesmen and practical men could be confined to those minor movements in the supply and demand for Bills of Exchange, which caused the variation of rates within the limits of the gold points, and which could be corrected by gold shipments, temporary borrowing, variations in the discount rate, and so on.

\$4. Schematically, the methods of exchange regulation may be divided up as follows* :-

(A) Increase in the means of purchase available abroad:(1) Appropriation of domestically held securities available for sale in foreign countries.

(2) Loans abroad from private individuals or governments or Banks.

(3) Export of gold.

(4) Differential prices, i.e., monopolisation or regulation of exports and export prices of articles with inelastic demand.

(B) Decrease in the necessity of payments abroad:(1) Restrictions on the importation of "luxury" goods.

(2) Restrictions on the exportation of capital by the purchase of foreign securities.

(3) Centralisation of exchange dealings by compulsory transfer of foreign currency to a central regulating authority.

(4) Prohibition of exports of local currency.

(C) Regulation of the fuctuations in value of local currency.

* The most convenient source of reference for the reader who does not desire great detail is Paper No. XI., presented to the Brussels International Financial Conference, entitled "Exchange Control." But a study of the files of the Board of Trade Journal, and the Review of the Foreign Press, is indispensable for a complete survey of the mass of legislation, most of it completely futile, dealing with the problem. 
(1) Rate fixing-" exchange pegging."

(2) Penalties for speculation in exchange.

$\S 5$. It will be observed that some of these methods have more than one aim in view. Thus centralisation of the purchase and sale of foreign exchange enables imports to be controlled and at the same time, in so far as it is successful, enables the government to prevent the speculator from buying and selling as freely as he otherwise could do. Again, the policy of "pegging" involves the policy of borrowing abroad and the centralisation of control over domestically held foreign securities, the policy of differential prices usually accompanies the policy of import restrictions, and so on.

§6. Of these various methods the most successful has been the policy known as "pegging " the exchanges, as practised by the British Government. This policy involves the possession of funds sufficient to buy at fixed prices, which are higher than those which the free play of market prices would of themselves establish, all the foreign bills offered, and thus to keep the price of the local currency higher in the particular market concerned than would otherwise be the case. Thus, to illustrate from the case of the London-New York rate, which was kept at four dollars and seventy-six cents for the greater part of the war, the British Government, through its New York agents, Messrs. J. P. Morgan \& Co., arranged that this firm should always have at its disposal sufficient funds to enter the market and buy bills at that price. These funds were obtained by the sale in New York of British-held dollar securities, which were obtained compulsorily from the British investor, or by the use of these securities as security for loans raised in New York : finally by loans obtained direct from the American Government after the United States had entered the war. It is obvious that the success of this policy involves the acquisition of funds enough to meet all bills offered in this way. 
Now this is just the danger of the policy. For the fact that the exchange is kept at the figure higher than that which would be brought about by the play of natural forces is of course a direct encouragement to further purchase : and every increase in the volume of payments to be made increases the cost of the scheme. The adoption of a policy of exchange-pegging leads naturally, therefore, to a further policy of import restriction: the idea being that if imports are confined to those sanctioned by the government the strain on the resources of the government will be reduced, and those imports which have in any case to be sanctioned, will cost less than would be the case otherwise.

§7. The simplest of all the possible devices for controlling exchange is that of fixing the price at which, inside the country itself, the local currency may be exchanged for world currency. This method is the application to the foreign exchanges of the policy of fixing prices. Price-fixing is generally made futile by the economic reactions which it sets up. It is not necessary to assume that the price regulation is deliberately avoided, though where the government is weak the price regulations are simply disregarded, as they are to a considerable extent in Germany and Austria to-day. Even where the price regulations are obeyed, however, the policy is unsuccessful in permanently achieving its ends. Suppose that the price is fixed low, so that buyers of the commodity in question find that their resources will enable them to obtain more of that commodity than they would have been able to do without the price regulation. The result is to stimulate purchases. On the other hand, sellers find that the prices they anticipated are not to be obtained, and reduce the production of the article in question. If the price is fixed high, on the other hand, buyers will not buy, sellers are encouraged to produce too much relatively to the level of demand at the price established by the government, and the result is waste of what is actually 
produced, until the producers have cut down their output to respond to the new level of demand.

Apply these reasonings to the case of the foreign exchanges, and the reader will have no difficulty in understanding why the simple fixing of exchange prices had in all cases to be followed by greater interferences in the working of the market. The object of the fixing of exchange prices was to enable foreign products to be obtained more cheaply than they would have been obtained otherwise, and this cheapness encouraged importation. But of course such increased importation resulted in a lack of the means of payment. The only alternatives open to the regulatory authority were to raise the price of foreign exchange, that is, to admit that its currency was worth less in fact than its official value : or to restrict importation in order to reduce the demand for foreign currency to the amount for which there was available means of payment so as to maintain the price. Quite apart from this inevitable result; the policy of fixing prices in the domestic market overlooked the fact that the price of the local, in terms of foreign currency, was determined not only in the home market, but also in the foreign centre. We have already seen that if the price of the same thing on the same day is different in two centres, then a speculative profit can be made out of an exploitation of these differences. Suppose that the price of marks in terms of Swiss francs is fixed in Berlin at such a rate that a mark can buy more than a mark will buy in Berne, where the value of marks is fixed in terms of demand and supply. Everyone in Germany with marks to sell in return for francs will buy his francs in Berlin, where the price favours him, but everyone in Germany with Swiss francs to sell will offer them in Berne, where the franc will buy a larger number of marks than francs will buy in Berlin. Having thus got a certain number of marks in Berne, it is possible to buy francs with them in Berlin, again exchange them for marks in Berne, and again register a profit. The 
result is naturally to make it more and more difficult to maintain the difference between the Berne and the Berlin prices, because the longer the regulatory authority delays in altering the Berlin price, the greater the profits which can be made at its expense.

The natural result of this is that complaints will begin to be made about the iniquity of speculators, and the government concerned will attempt to differentiate between legitimate and illegitimate demands for foreign exchange. Finally it ends up by requiring proof that the person demanding remittance has really imported goods, and from this is it an easy step to lay down the principle that only certain classes of imports shall be allowed.

$\S 8$. The policy of gold exports, although it has had the effect of transferring to the neutral nations and to Japan and the United States a considerable part of the gold formerly possessed by the European belligerents, is quantitatively not an important aspect of the exchange policies of the belligerents. This is simply due to the fact that the stores of gold possessed by most of them were not great in relation to the payments which they were required to make. But, apart from the insufficiency of the actual gold available, the European governments were not able to export all the gold which they had at their command. For the greater part of the war psychological influences had to be carefully considered. It would appear natural that the complete loss of the gold stores of the central banks should impress the subjects of the various states as presaging national bankruptcy. But in fact it is obvious that statesmen have exaggerated the extent to which the modern European is wedded to the idea of a gold currency. This is shown by the readiness of people inside a country to go on accepting a currency which neutral markets mark down as nearly worthless. The fact that in effect the currency of most European countries is actually inconvertible shows that the greater part of the gold 
could have been exported without the actual course of events, so far as the acceptibility of the currency is concerned, having been different to what it in fact has been.

$\S 9$. When we come to the group of methods associated with the manipulation of imports and exports, such as the restriction on the importation of different classes of goods, or the prohibition of the exportation of capital, or the fixing of differential prices for goods exported, we find that it is possible to defend these devices on two sets of grounds, so far as their effect on the foreign exchanges is concerned.

Firstly, it may be argued that it is possible to alter the component sides of the "Balance of Trade" in such a way that the ratio of imports to exports becomes more favourable. The net effect is to improve the value of the domestic currency in terms of foreign currency, either by making the foreigner pay more than he would otherwise do, or by reducing the amount owed to the foreigner: for less is bought from him, or less is lent to him.*

The second group of arguments is rather different. It may be held that whilst it is not possible by these devices to improve the ratio of value between the local and the foreign currency, it is possible to substitute one kind of import for another, without making the exchange any worse. In other words, the rate of exchange will be at least as good when the goods have been substituted as it was before.

Is there any validity in these ideas?

1. Restriction of luxury imports.

The assumption here is that the demand for the products of the importing country will not fall off whilst the products of the luxury-producing countries are sharply cut down. Now it will take some time for the sources of supply to be altered, so that, if country A exports wine and imports cotton goods from country B, in the short run cotton goods may still be got from $B$

* Capital exports are loans to a foreign country. 
in spite of the fact that wine is no longer sold there. But it ought to be perfectly obvious that this is a state of affairs that cannot possibly last. For the ultimate source of payment for the cotton goods is the wine exported. It may be argued that an alternative market for the wine may be found elsewhere, so that a new three-corneredtrade may come into existence. Thus, wine is exported to a third country $\mathrm{C}$, which exports wheat to $\mathrm{B}$, which continues to export cotton to country A. But, quite apart from the fact that three-cornered-trade of this kind does not improve the exchanges but only effects a substitution of one kind of article for another, it should be clear that the condition for increasing the exports of wine to a third country in this way, other things equal, is that the price of wine is lowered, which ultimately means that not as much can be exported in terms of cotton as was exported before, which again means that not so much wheat can be imported.

Putting this in to the terms of economics, the assumption is that the demand for the exports of the country restricting the imports of luxuries is inelastic. That is, it is assumed that though the luxuries may cease to be bought, the need for the cotton goods is so urgent that the cotton goods will continue to be bought in spite of the more disadvantageous terms on which they must now be acquired. But this assumption is not necessarily true, and, if true, only true within narrow limits. The more elastic the demand for the cotton goods, the more rapidly will the demand for them fall off; in other words, the more rapidly will exports of cotton goods be adjusted to the smaller imports of luxuries.

Does it follow from this that the cutting off of luxury imports is to be condemned? Not in the least. For though such a restriction of imports will not necessarily improve the exchanges, even in the short run; it may be desirable that the government of the country should obtain the resources that were formerly spent on luxuries. That is, the case for cutting down the imports of silk stockings and champagne into Germany and Austria 
is not that thereby the exchange will be appreciably improved, but that in these countries the available resources for buying things in general are so limited that to spend any of them on these articles is a waste of the national resources.

It has been noticed by Prof. Pigou that if the action of the State is confined to limiting or prohibiting the imports of luxuries, and does not extend to restricting the production of similar articles inside the country, " a policy of restricting imports may, in conceivable though improbable conditions, defeat itself by causing resources to be withdrawn from the manufacture of export goods, in order to make substitutes for the extruded imports to such an extent that the export side of the trade balance is lowered more than the import side."* There may be an improbability of this particular case occurring in practice, but there is nothing improbable in the idea of the extruded product being manufactured at home, and something else being imported in place of these extruded imports. Thus, the export trades may export as much as they did before, but the only change will be in the imports; some permitted import will take the place of the prohibited ones. It will in any case be noted that Prof. Pigou concedes that the export side will be affected; in my opinion, even if the export side is affected at all to the same extent, there will be no improvement, let alone the case in which the export side is more affected than the import side.

2. Prohibition of Capital Exports.

The prohibition of capital exports requires a mechanism of control more elaborate than the mere prohibition of imports. In order to realise the desired end, exporters must show that they have received payment for their exports within a defined period of time, and must turn over this payment to the government or must import approved commodities with it; importers must show why they desire to remit abroad, and the supply of funds to would-be investors abroad is stopped by embargo.

* Economic Journal, Dec. 20, p. 471. 
The effects of the stopping of capital exports turns on whether or not the export contemplated is the result of a previous sale or not. When, for instance, cotton goods have been exported and the proceeds of the sale are taken over by the government to pay for imports of foodstuffs, the effect on the exchanges is exactly the same directly as if a capital export had taken place. The only difference is that food is imported instead of non-importable property being acquired. If it is argued that this acquisition of foreign money by the government cuts down the total volume of payments to be made, this assumes that the recipient of the local money in exchange for the foreign money with which he is forced to part, spends no part of it in acquiring other foreign goods. In that case there will be, in addition to the foodstuffs, other imports which do not fall into the category of capital acquisitions and are therefore allowed. In this case the effect on the foreign exchanges is nil.

The argument that the stopping of capital exports will improve the exchanges assumes further that people will be as willing to sell abroad when they cannot control the disposition of the resulting credits as they were when the disposal of the proceeds was left free. But this is not at all true-universally. The fact that capital abroad is to be acquired shows that the investor either distrusts the legal or political situation at home, or fears that the local currency will become more depreciated still, or that the chances of profit will be less if he sells at home. Under these circumstances it is not at all obvious that the stopping of capital exports will put an equivalent amount of funds at the disposal of the regulatory authority.*

3. Differential Prices to the Foreigner.

The argument that putting up the price to the foreigner will increase the amount at the disposal of the country

* Prof. Pigou is willing to admit that in the long run the checking of capital exports may make the trade balance less advantageous, the reason being that the income which would be drawn from abroad, were the investment allowed, is lost through the prohibition. But I cannot follow him in thinking that the prohibition "must, successful, improve the current .... trade balance." Op.cit. et.loc. cit. 
exporting the goods in question depends for its validity on the assumption that the exports are monopolised by the country concerned, and that the demand is so inelastic that so much will be bought when the price is high that the aggregate income from the sale will be greater than it would have been if the price had not been controlled. This seems to me to be altogether questionable. In so far as the aggregate income is cut down owing to the demand falling off, the effect on the exchanges is to make them less favourable than they would have been otherwise. Further, even if the demand for that commodity does not fall off, there is no reason to suppose that the demand for other exports will not fall off, so that nothing is gained in the long run by the policy. As a matter of fact, differential prices are generally imposed not so much to improve the exchanges as to balance the artificially lower prices maintained at home, and the aggregate effects on the exchanges of this policy is hardly taken into account.

$\S 10$. We now come to the last of the methods of which a word need be said in this chapter. This is the prohibition of the export of the local currency. This is enforced on two grounds. First, in order to prevent the purchase of goods for which there is available no other kind of payment, the idea being that thereby the value of the local currency is improved. Second, the presence of large masses of this local currency in foreign monetary centres is an inducement to speculation. Supposing that this money were not exported, what would happen? It seems fairly obvious that it is not the export of the money which is the cause of depreciation, but the overissue of this money. The only effect of keeping the money at home is to raise prices at home still more, and thus to cause the demand for goods from that country to fall off, so that the " Balance of Trade," gets worse in any case. As for the influence of speculation, it is not the speculation that makes the exchanges get worse, but the worsening of the exchanges which makes it worth 
while to speculate, though it is true that if the speculation is for the rise, anything which worsens the position of the country will cause the exchanges to decline sharply. But this is only anticipating the result which would in any case be produced if the anticipations are realised by the financial policy of the country.*

The plea that the speculator is responsible for the worsening of economic conditions is a favourite method by which governments attempt to shift on to other shoulders the responsibility for conditions which they are chiefly responsible for themselves. It was thus with the heinous crime of " profiteering." Now that prices are coming down we hear less of this particular crime, and its place is being taken by the speculator in foreign exchange. What is wrong with exchange speculation is only what is wrong with most other forms of speculation-the hope of getting rich quickly attracts a large number of persons who know nothing of the rules of the game. But it is quite easy to stop the evil of speculation in foreign exchange. All that is required is to cease the creation of the instrument of speculation. Until this is done, to prevent the export of these speculative instruments is like altering the thermometer because it registers too much warmth in a room in which all the windows are sealed up and a roaring fire has been kindled.

$\S 11$. The reader will see that I have been arguing on the assumption that the advocates of the balance of trade theory are correct in their fundamental contention. Even on this basis, however, there is very little to be said in favour of these various methods. The present position of the European foreign exchanges is proof enough of their comparative failure in practice. It is therefore necessary to examine the present exchange position from a fresh point of view.

* The fact that a large number of people have lost greatly by speculation in foreign currencies shows that if the market had been as "bearish" in sentiment as the subsequent facts would have justified it in being, the fall would have been even sharper than it has been, 


\section{CHAPTER VI.}

\section{THE PRESENT POSITION OF THE FOREIGN EXCHANGES.}

$\S 1$. The reader will not have failed to notice that in previous chapters I have insisted on going behind the explanation that the balance of trade settles the rate of exchange and asking what is the reason that the balance is what it is. We saw that the effect of gold movements or of discount variations was to reduce the price level to such a degree as to make it again worth one's while to buy from the country. In other words the fundamental factor which must be considered is not the relative amounts bought and sold across national frontiers in a given period but the price levels which are the cause of these trade movements.

The theory of the exchanges associated with the name of Prof. Gustav Cassel of the University of Stockholm is nothing but an elaboration of this central fact. There is nothing in the theory which is essentially new : from the days of the Bullion Committee of 1810 it has been part of the accepted body of economic teachings that the increase of inconvertible* paper money would turn the exchanges against the country. I do not think that there is any text book which specifically denies the truth of this contention: though it occupies a subordinate place in most treatises, for the simple reason that the pre-war position was that most countries possessed either an exportable gold currency, or a gold exchange currency, or, a paper currency which, if inflated, was so little inflated in terms of the present position that the inflation did not make very much difference.

It must not be imagined that the pre-war exchanges did not obey the law which will be formally set out in a moment. The fact is that the self-adjustment of the

* In these days it is not the inconvertibility of the paper, but the non-exportability of the coin into which this paper is convertible, which provides the direct cause of over issue. 
exchanges was so rapid that it was easy to overlook the fundamental reasons, and to concentrate attention on the minute deviations from the par which are statistically portrayed in the appendix.

$\S 2$. The Cassel Theory assumes the truth of what is generally known as the Quantity Theory of Money. This theory is nothing but the formal expression of the truth that as the quantity of goods decreases, and the quantity of money increases, the prices of the goods expressed in terms of the money rise, and the price of the money expressed in terms of the goods falls. It is possible to quarrel as to what constitutes money; it is also possible to quarrel as to the immediacy with which an increase in the quantity of money, or a decrease in the quantity of goods, will lead to a rise. It is also possible to question the exactness of the result, in the sense that it may be argued that a doubling of the money will not necessarily lead to a doubling of prices, and so on. All this does not concern us here, however. The general truth that an increase in the quantity of money and a decrease in the quantity of goods will raise prices has ceased to be a mere academic proposition since the enormous increase of paper money began in 1914 and has gone on from that time to this.

At any particular moment, therefore, the stock of goods being given, the quantity of money and the price level stand in reciprocal relation to one another. But in addition to the stock of goods being given, we must also assume a certain velocity of circulation. That is to say, if a given piece of money passes from hand to hand during a period of time a given number of times, and then, subsequently, this velocity is increased, that is equivalent to an increase in the quantity of money, for an increase in the velocity means that the number of pieces which would be required, if the price level is to remain unchanged, is less than it was before. Similarly, a decrease in the velocity of circulation is equivalent to a decrease in the quantity of money, because it implies that to maintain 
a certain level of prices, the quantity of money must be increased.

§3. During the war, the stock of goods and the quantity of money have certainly altered. It is by no means clear what has happened to the velocity of circulation. But if one considers the degree to which the peasants of Russia, Central Europe, and one supposes also France, have been hoarding money, it seems probable that the average velocity of circulation in these areas has fallen. But the whole matter is much more doubtful than is the increase in the quantity of money and the fall in the quantity of goods; although production is now again increasing

$\S 4$. If we suppose that there are a group of countries all in touch with one another, it is obvious that the same articles will cost the same amount in all of them. For if the price of one of them is higher in one place than in another by more than the cost of transport, it is clear that the goods will move from the low-priced area to the high-priced area. The value of money will be raised in the area to which the goods move, for each unit of money will fetch more in goods than it did before. In the area from which the goods came, the value of money will fall, that is, each unit of money will fetch less than it did before. In this way there will tend to be established a uniform price level, or what is the same thing, the value of money in all the different places will tend to be the same. If all the countries are using the same money, then money will move from the places where its value is low to the places where its value is high, and the goods will move to the places where their value is high, that is, to those places where the value of money is low.

The value of the money of each of these countries in terms of the other monies will stand in a definite ratio to the amount of goods it can buy. It is fairly easy to see that the value of the money of one of these places, relative to the money of any other of these places will depend 
on their relative purchasing powers: that is, that the rate of the exchange between these various currencies will be as the ratio of the price levels in the respective countries.

Before the war, this adjustment was very easy, because not only the goods but also the money moved quite easily from one place to another, and therefore both the money and the goods tended to have the same value in all places.

$\S 5$. The Cassel Theory is nothing but a generalisation of this reasoning. It asserts that the rates of exchange between different currencies are determined by the relative purchasing power of these currencies. But as the present European currencies have only a direct purchasing power inside the issuing country, it is perhaps easier to put this truth in the form that the rates of exchange are determined by the relative quantities of money issued by different countries, though as the price level is influenced by other things as well as the quantity of money, this latter way of speaking is the less accurate.

$\S 6$. It is so essential that the full implications of this principle should be grasped that further explanations may not be out of place. We may put the position in these terms. If the price level of one country is higher than the price levels in other countries, then the condition for export from that country to the others is that the rate of exchange between its currency and that of the others should be such that the fall in the exchange should compensate for the rise in the internal price level. If the fall in the exchange is less than sufficient to compensate the rise in the price level, exports will fall off ; if the price level is more than compensated by the fall in the exchange rates exports will be stimulated, for the time being. But the stimulus to exports will raise prices inside the country still more, and thus cause the domestic price level and the exchange rates to correspond : in the other case, when imports are stimulated, the 
price level in other countries will rise, and thus again cause the price level all over the area to correspond to the exchange rates established.

In other words, the theory asserts that, not the balance of trade, but the relative price levels, ultimately determine the rates of exchange. It follows that the maxim that countries should export more than they import, in order to increase the foreign value of their currency, sets up an impossible demand if the internal price level is higher than the price level in the rest of the world. The condition for increased exports in such a case is a depreciation of the exchanges at least great enough to compensate for the difference in price levels, otherwise it is impossible to export at all.

$\S 7$. We can illustrate the position as follows :-

Suppose that there are two countries, each with a currency nominally containing 100 grains of gold. The par of exchange between the two currencies will then be unity. Now, suppose that both of them resort to an inconvertible paper currency. Let the quantity of currency be doubled in the first country, and quadrupled in the second. Then the rates of exchange will no longer be unity, but one unit of currency of the first country will buy two units of the currency of the second country.

$\S 8$. The rate of exchange which is given by a comparison of the price levels of two countries is called by Professor Cassel the "Purchasing Power Parity." If we know the increase in the price levels in two countries, then the actual rates of exchange are at parity when the ratio between them corresponds to the purchasing power parity as expressed by the ratio of the price levels in the two countries. The peculiarity of the purchasing power parity is that it is a moving par, it varies with every change in the price levels in the two countries.

$\S 9$. It follows that, if two countries increase their price levels to the same extent, the rate of exchange between 
them will still be the same as it was before the price changes took place. One unit of the currency of each will buy as much in the other country as it does in the country of issue, and hence the ratio of interchange between them will be the same. It is only when the rate of increase in the price level is different in the two countries that the purchasing power parity departs from the nominal par. In this case the country with the highest price level finds that the foreign value of its currency falls more and more in terms of currencies with a higher purchasing power than its own.

$\S 10$. We can now give an alternative explanation of the exchange methods outlined in the previous chapter on the basis of the present theory. Exchange pegging is successful in so far as it enables the importing country to keep its prices down and causes prices in the exporting country to rise. So long as the United States gave credits to the British and other Governments, they were enabled to buy articles in the United States with American money, which the Allied Governments allowed their subjects to obtain at a fixed price which bore no relation at all to the levels of prices in the two countries. This procedure naturally encouraged purchases in the United States, and, by doing so, helped to raise prices in the States, and to bring them down in the Allied countries. That is, pegging helped to establish a purchasing power parity closer to the pegged rate by stimulating a transference of goods from America to Europe. In other words, without pegging, equilibrium would have been established by so rapid a fall in the exchange that the profit from selling in high-priced Europe rather than in low-priced America would have been wiped out; with pegging some approximation to equilibrium was brought about by raising American prices more to the European level, so that the actual rates tended to be at last a pale reflection of the relative price levels.

The policy of differential prices, we can now see, means that the prices in the country practising this policy 
tend to be raised artificially, for foreigners. This tends to reduce the value of the currency of that country, for, if the export price of coal is raised, one English paper pound buys less of it, when the pound is held by a foreigner, than previously. If the result of high export prices is a still higher rise in the level of prices in the purchasing country, then the effect will be, for the time being, a depreciation of the rate from the standpoint of the buying, and an improvement from the standpoint of the selling country, in so far as the price level is seriously affected by the articles in question.

But notice that all that this implies is that the rate "improves" because prices in the buying country go still higher than they were before, absolutely and relatively. If the rate was previously appreciated in terms of the buying country's currency, such a situation means that the "improvement" of the currency, in terms of the selling country, is bought at the expense of a further dislocation of the international price level.

We can now also see why the prohibition of the export of currency is utterly useless. Suppose it not exported, then prices at home will rise the faster and depreciate the exchanges just in the same way as if the currency had been exported, and had been offered for what it would fetch abroad.

$\S 11$. If the actual rates of exchange from the end of the war to the middle of this year are examined, it is found that the requirements of the theory are not completely borne out in practice. Thus, if the rate of exchange is the expression of the relative price levels, we should expect the statistical material available to bear this out. When the matter is looked into however, it is discovered that, in the early part of 1919, the rates of exchange, looked at from the European point of view, were higher than they ought to have been, and recently they are lower than they ought to be, when the internal and the external price levels are taken into account. 
Thus, Table J, on page 23 of the Volume of Currency Statistics, published by the League of Nations for the use of the Brussels Financial Conference, shows that the actual cost of obtaining American dollars and the required cost necessary to equilibrate the internal price level with the American level, are as follows, for various European countries:-

Percentage Change in Cost of Dollar.

\begin{tabular}{|c|c|c|c|c|c|c|c|c|c|c|c|c|}
\hline \multirow{2}{*}{ Date. } & \multicolumn{2}{|c|}{$\begin{array}{c}\text { France. } \\
\text { Actual. Rqd. }\end{array}$} & \multicolumn{2}{|c|}{$\begin{array}{c}\text { Italy. } \\
\text { Actual. Rqd. }\end{array}$} & \multicolumn{2}{|c|}{$\begin{array}{c}\text { United } \\
\text { Kingujom. } \\
\text { Actual. Rqd. }\end{array}$} & \multicolumn{2}{|c|}{$\begin{array}{l}\text { Sweden. } \\
\text { Actual. Rqd. }\end{array}$} & \multicolumn{2}{|c|}{$\begin{array}{c}\text { Canada. } \\
\text { Actual. Rqd. }\end{array}$} & \multicolumn{2}{|c|}{$\begin{array}{c}\text { Japan. } \\
\text { Actual. Rqd }\end{array}$} \\
\hline & 10 & $\ldots$ & 10 & - & 10 & - & 100 & $\ldots$ & & - & & - \\
\hline 20 & 10 & 140 & 10 & 114 & 10 & 107 & i & 157 & & 100 & & 131 \\
\hline & 14 & 14 & 12 & 11 & & is & & 1 & & 991 & & 139 \\
\hline & is & 15 & 16 & 12 & 12 & & & & & & & is \\
\hline & 25 & 19 & 26 & 16 & 11 & & 12 & 14 & ic & 100 & & 151 \\
\hline & 215 & 18 & 21 & 209 & 117 & 106 & 125 & 133 & 110 & 96 & 115 & 119 \\
\hline
\end{tabular}

$\$ 12$. The problem which is indicated by these figures is that of the "over-valuation" and the "undervaluation " of currencies in terms of the purchasing power parity : a problem described by Prof. Cassel as "one of the most intricate, most actual, and practically most important chapters of economic science." The problem is interesting not only for its own sake, but because the solution propounded by Prof. Cassel has led to the charge that he is an apostate from his own theories. It is an interesting sign of the internationalism of economic science that this charge should have been brought against the Swedish professor by a Dutch woman economist in the pages of an English review.

The original solution propounded by Prof. Cassel was that these abnormal deviations from the purchasing power parity were due to "one-sided restrictions" on trade. Thus the Swedish Crown was over-valued in this country, in the United States, and very greatly in Germany. To what could this over-valuation be attributed ? To the fact, answered Prof. Cassel, that the war policy of the belligerents imposed unusual restrictions on goods moving to Sweden, whilst they did not impose similar restrictions 
on goods coming from Sweden, and even forced the entry of the latter by pressure on the Swedes to grant war credits. "The result of these ${ }_{\text { }}$ artificial conditions of Sweden's international trade has been an unprecedented accumulation of assets in foreign cour-tries together with a great import of Swedish securities from abroad."

This sentence was seized upon by Miss Van Dorp of the University of Utrecht. To her mind this indicated that the old conception, which Prof. Cassel had previously rejected, viz., that rates of exchange were determined by the balance of trade, was being insidiously reintroduced by the Swedish economists. Her own solution was that the problem only existed because the basis taken for the valuation of the parity was defective, in so far as the only prices which ought to be taken into account should be the export prices, and not all prices, because the war restrictions have created two price levels, one for foreign trade and for internal trade, the latter of which did not count.

As a matter of fact, the explanation of these abnormal deviations furnished by Prof. Cassel in his memorandum to the Brussels Conference, and earlier in an article in the Economic Journal, on the position of the German mark, whilst not retracting from the previous statement as to "one-sided" interferences with trade, has been amplified by reference to the influence of speculative opinion. When a country exports its own currency for sale to speculators it must reduce the price to these speculators in order that they may make the anticipated profits. This in part accounts for the fall in value of the lire, the franc, and especially the German mark.

What is the real explanation of this interesting problem? I venture, though with some hesitation, to put forward the following remarks.

Prof. Pigou, in his recent article in the Economic Journal, has drawn pointed attention to the discrepant results derived from different series of index numbers. The point can be shortly illustrated here by bringing up to a more recent date the table quoted on a previous page. 
(1) UNITED KINGDOM-U.S.A. RATE.

\begin{tabular}{|c|c|c|c|c|c|}
\hline Month. & $\begin{array}{l}\text { U.K.Board } \\
\text { of Trade } \\
\text { Index No. }\end{array}$ & $\begin{array}{l}\text { U.S.A. Bureau } \\
\text { of Labour } \\
\text { Index No. }\end{array}$ & $\begin{array}{l}\text { " Reqd." value } \\
\text { of pound in } \\
\text { terms of } \$ \text {. }\end{array}$ & $\begin{array}{l}\text { Reqd. value of } \\
\text { ser cent. }\end{array}$ & $\begin{array}{c}\text { Actual } \\
\text { Percentage } \\
\text { of parity. }\end{array}$ \\
\hline $\begin{array}{l}\text { June, } 1920 \\
\text { July, } 1920 \\
\text { August, 1920 } \\
\text { September, } 1920 \\
\text { Octoher, 1920 }\end{array}$ & $\begin{array}{l}338 \\
\mathbf{3 4 7} \\
326 \\
331 \\
324\end{array}$ & $\begin{array}{l}269 \\
262 \\
250 \\
242 \\
225\end{array}$ & $\begin{array}{l}\$ 3.86 \\
\$ 3.67 \\
\$ 3.70 \\
\$ 3.60 \\
\$ 3.38\end{array}$ & $\begin{array}{l}79.42 \\
75.51 \\
76.13 \\
74.48 \\
69.55\end{array}$ & $\begin{array}{l}81.42 \\
76.59 \\
73.67 \\
71.15 \\
71.10\end{array}$ \\
\hline
\end{tabular}

(2) UNITED KINGDOM-SWEDEN.

\begin{tabular}{cc|c|c|c|c}
\hline Month. & $\begin{array}{c}\text { U.K. } \\
\text { Index. }\end{array}$ & $\begin{array}{c}\text { Swedish } \\
\text { Index. }\end{array}$ & $\begin{array}{c}\text { Reqd. value of } \\
\text { £ per cent. }\end{array}$ & $\begin{array}{c}\text { Actual Percentage } \\
\text { of parity. }\end{array}$ \\
\hline June, 1920 & $\ldots$ & $\mathbf{3 3 8}$ & 366 & 92.1 & 100.33 \\
July, 1920 & $\ldots$ & $\mathbf{3 4 8}$ & 363 & 95.9 & 102.60 \\
August, 1920 & $\ldots$ & 326 & 365 & 89.3 & 102.89 \\
September, 1920... & $\mathbf{3 3 1}$ & $\mathbf{3 6 2}$ & 90.1 & 103.44 \\
\hline
\end{tabular}

(3) UNITED KINGDOM-FRANCE.

\begin{tabular}{|c|c|c|c|c|}
\hline Month. & $\begin{array}{l}\text { U.K. } \\
\text { Index. }\end{array}$ & $\begin{array}{l}\text { French } \\
\text { Index. }\end{array}$ & $\begin{array}{l}\text { Reqd. value of } \\
\text { of fcs. per cent. }\end{array}$ & $\begin{array}{c}\text { Actual Percentage } \\
\text { of parity. }\end{array}$ \\
\hline $\begin{array}{l}\text { June, } 1920 \\
\text { July, 1920 } \\
\text { August, 1920 } \\
\text { September, 1920 }\end{array}$ & $\begin{array}{l}291 \\
293 \\
288 \\
284 \\
\end{array}$ & $\begin{array}{l}495 \\
498 \\
504 \\
528 \\
\end{array}$ & $\begin{array}{l}170 \\
170 \\
176 \\
186 \\
\end{array}$ & $\begin{array}{l}188 \\
195 \\
202 \\
207 \\
\end{array}$ \\
\hline
\end{tabular}

(4) UNITED KINGDOM-ITALY.

\begin{tabular}{|c|c|c|c|c|}
\hline Month. & $\begin{array}{l}\text { U.K. } \\
\text { Index. }\end{array}$ & $\begin{array}{l}\text { Italian } \\
\text { Index. }\end{array}$ & $\begin{array}{l}\text { Reqd, value of } \\
\text { of } f \text { per cent. }\end{array}$ & $\begin{array}{c}\text { Actual Percentage } \\
\text { of parity. }\end{array}$ \\
\hline $\begin{array}{ll}\text { June, } 1920 & \ldots \\
\text { July, 1920 } & \ldots \\
\text { August, 1920 } & \ldots \\
\text { September, } 1920\end{array}$ & $\begin{array}{l}291 \\
293 \\
288 \\
284 \\
\end{array}$ & $\begin{array}{l}615 \\
613 \\
632 \\
661 \\
\end{array}$ & $\begin{array}{l}47.3 \\
47.8 \\
45.5 \\
42.9 \\
\end{array}$ & $\begin{array}{l}39.10 \\
35.90 \\
32.80 \\
30.10 \\
\end{array}$ \\
\hline
\end{tabular}

These tables illustrate the close relationship between " required" and " actual" rates in the case of the United Kingdom and the United States rate, and the dependence of the results on the index numbers chosen. In the case of America and Sweden, prices there were compared with Board of Trade prices : in the case of France and Italy, prices there were compared with Economist prices. Had the reverse selection been made, the divergence between "actual " and "required" ratios would in all cases have been greater than it actually is.

To some extent, unfortunately an unknown extent, the problem is thus one of statistical method. But the fact that the divergence follows on what we might call a priori lines the one striking phenomenon which distinguished the various European countries among themselves, serves to show that there is one other element at work. The influence of import and export restrictions, 
price controls, differential prices for the foreigner and the rest of the devices which we have outlined are nowadays, or were until recently, too common for us to place much reliance on them as an explanation. What is markedly different in different countries is the degree of inflation, and it is, to say the least of it, singular that it is those nations which have fared worst in this respect that show the worst divergence between required and actual parities.

We may say, then, that the actual divergences are largely due to the effects which the anticipated further inflation has exercised upon the exchange market. And we may say that the appreciation of certain currencies during and after the war is due to the over-estimation which holders of Swedish Crowns put on them owing to the supposed advantages of the war to Sweden and other neutral nations. That is, Sewdish currency was overvalued during the war, not because of the balance of trade, but because holders of Swedish Crowns overestimated future profits, and German marks have been depreciating in proportion as the chances of future appreciation became more and more remote : that is, as holders realised that they have been over-estimating German recovery.*

It is generally said that the "credit" of nations affects the rate of exchange. In the usual way in which this statement is put it is erroneous. To produce any effect on the rate of exchange, the credit of nations must influence the market supply or demand. But at the present time the market is affected by the situation of the European belligerents. To complain of the effects of speculation in this connection is to put the cart before the horse: the speculator is preparing the position which the currencies of these countries must assume if no remedial measures are undertaken.

Our final task must be to indicate what must be the line of reform. This is the object of the next and final chapter.

* The over-estimation of Allied currency in America is simply due to the fact that the Governments of these countries sold American money to their subjects at uneconomic rates. 


\section{CHAPTER VII.-REMEDIES.}

$\S 1$. One practical conclusion of the utmost importance, which derives from the theory we have just been discussing, now requires to be emphasised. If the rate of exchange between two countries is determined by their respective price levels, it follows that as soon as stability has been reached, the rates of exchange will be stable also. Consequently, the first and most direct method of stabilising the rates of exchange is to stabilise the price levels. If, thereafter, the rate is to remain stabilised, then the price movements in the two areas must move in the same direction, and move in that direction at an equal rate. So far as the stability of the rate is concerned, it makes no difference what the internal and external level of prices at the moment of stabilisation may be, provided only that we can be sure that the price level is stable.

$\S 2$. But although it is easy to see that stability in the price levels will, under the circumstances, produce stability in the exchanges, it is important to notice that, as things are, the fluctuations in the rate will tend to be larger than they were before the war. This is due to the simple fact that the unit of measurement is no longer the same. If we have a country with, roughly, the same population and the same volume of international trade, but that country uses ten times the amount of pre-war currency, it is obvious that a fluctuation of ten units in the rate now is only equivalent to a movement of one unit in the rate before the war, and a movement of one unit in the rate now is only equal to a movement of onetenth of a unit in pre-war days. This is an important point, because an exaggerated attention is paid to the quantitative aspect of fluctuations at the present time. This is due to the fact that the exchange records still use the old par of exchange as if it were the actual par of to-day. But this is not the case. The actual par is the purchasing power parity, and, owing to the fact that the 
degree of inflation is different in different countries, and since the currency is non-exportable in the sense that gold was, which possessed an universal purchasing power, the real rates of interchange between dollars and pounds, lire and marks, roubles and crowns, are entirely different to what they were. Before the war, the gold pound, the gold franc, the gold dollar, and the gold mark could not for long possess a different purchasing power, because if they did, they were simply exported. To-day, far from the export of paper pounds, paper francs, paper marks and crowns improving the exchange, it tends to confirm the opinion that the economic position of these countries is deteriorating, and simply heralds the decline in the international value of these currencies which the increase in their volume will bring about in any case.

$\S 3$. The proposition that the price levels should in all countries be stabilised requires a two-fold series of measures. First, it requires an act of self-sacrifice on the part of the issuing countries. "No more paper money" must be the first act in the regeneration of the European situation.

It is, of course, much easier to say " no more paper money" than to practise such a self-sacrificing policy. But, unless the flood of paper money is stopped, the attempt to improve the rate of exchange is hopeless from the very start. For increasing quantities of paper money cannot help altering the purchasing power pars, that is, depreciating the exchanges.

The second necessity is to allow prices to find their own level, without any let or hindrance. For the last seven years the statesmen of the world, having first enormously increased the supplies of money with which they hoped to conceal from their subjects the inconvenient fact that war is an expensive amusement, have been sedulously adopting a series of devices to prevent prices from rising, or for preventing the cost of goods from abroad responding to the altered parity of the local currency. It is fairly clear that there cannot be a stable price level until these 
various practices are stopped, because these simply prevent the truth from becoming apparent as quickly as it would otherwise. It is on grounds of this sort that the Brussels Conference unanimously called for a halt and for a freeing of the exchanges from artificial control.

$\S 4$. Before we face what are the ultimate difficulties, let us face what are the immediate stumbling blocks. The first of these is the undervaluation of certain currencies. Let us assume what is, after all, not quite certain, that the currencies of certain states are greatly undervalued in the exchange markets of the world. How are such currencies to be brought up to their purchasing power parities? Suppose, to take a concrete illustration, that Germany refrains from increasing the currency any more, and that prices, after a period of great instability, finally settle down at a level which corresponds to the increase of the currency. This increase is not quite clearly known, but the relative amounts of the note issues of this country and Germany at the end of October, 1920 , amounted to $3,760-463$, so that German prices should be about eight times the English prices of that date. One paper pound should, therefore, buy 160 German marks ; but, in fact, it bought in the neighbourhood of 240, taking the average between the highest (262) and the lowest (212) quotation for the month. This indicates that German prices should be about twelve times the English prices, before the internal and the external value of the mark correspond on the basis of actual exchange rates. This seems to indicate a considerable undervaluation of the mark abroad.*

Assuming that there is such a phenomenon as undervaluation, one of two possibilities lies open. The first is to allow the undervaluation slowly to correct itself,

* It is, however, interesting to find the International Bulletin of Statistics for October-November, 1920, p.vii., under the heading of "Cost of living in Germany," stating that the "cost of living in Frankfort-on-Main (100 on April 1, 1919, 26.5 on January 1, 1914) has risen in the period September 1-November 1, from 281 to 316 . The cost of ving bas thus increased twelvo-fold since January, 1914 . . ." 
by the importation of the undervalued money into the country of issue. This will of course mean that the the process of immediate stabilisation will be impeded, for the effect of the reimportation is a further rise of prices, and this may in itself produce further undervaluation, so that the wished-for stability will be further delayed.

The simpler method is not to adjust the internal price level to the total quantity of money in this way: but to adjust the quantity of money to the price level. In other words, the overplus of money should be removed: and this can best be carried out by means of funding the paper money, that is, by offering to the speculator a fixed interest sum in place of the profits that he might have made by holding the money until its value had improved. It is in this way that the problem of German money in Belgium has been solved : the money has been funded: or turned into a loan from the noteholders to the German Government.

Once a sufficient quantity of the surplus money has been funded to bring the international value of the money into line with the purchasing power parity, and granted that the issue of new money is definitely stopped, the further export of money presents no difficulty. For the money so exported will reduce the supply at home : that is, it must be taken out of the circulation. But this is a different thing from saying that the export of the local money should be permitted during the period in which the old money is being funded. If the terms of the loan appear to holders inside the country to be more attractive than the use of the money for ordinary loans or purchases, then there may be an increased export which would make the funding an onerous task. But there is no reason why those notes which are not presented for funding should be demonetised within a defined period of time, so as to force the holder to realise as quickly as possible. The danger of export within the period of funding cannot be entirely safeguarded against. The method of stamping cannot solve the difficulty, for 
the foreign notes obviously cannot be stamped without great difficulty, and the unstamped internal notes will the more easily pass as foreign held.

$\S 5$. The next difficulty concerns the deflation process in the countries which are still on a gold basis or which possess currencies which can be easily or relatively easily brought back to a gold basis. If there is deflation in the better off countries, it will worsen the position in the countries which have most largely inflated their currencies. Thus the deflation which has been going on in the United Kingdom in recent months has failed in bringing the American Exchange to parity, not because of anything concerned with the balance of trade, but because deflation has been proceeding more rapidly in the States than it has here. Similarly, the improvement in the Spanish and Danish Exchanges is to be more largely attributed to the increased note issues in the two countries than to anything else.

$\S 6$. This brings one to the central difficulty. Deflation assumes that prices should not be stabilised at the existing level, but that it is desirable that prices should be reduced. But this is not by any means a matter upon which all persons are agreed. Assuming that it is desirable that prices should be reduced, by how much should they be reduced? And assuming that a certain reduction is considered in the better off countries to be economically desirable, by how much should prices be reduced in the worse-off countries?

Supposing that we think that it is desirable that prices in countries such as the United Kingdom and South Africa, now both of them on a basis of inconvertible paper money, should be brought to the level of American prices. If American prices are also falling, this means that the rate of deflation in the countries named must be more rapid than deflation in America, and it means that to maintain even the existing rates of exchange deflation must be still more rapid in Germany, France, 
and the other countries of the European Continent. If the existing rates are to be positively improved, then the rate of deflation must be still further increased. And this is where the difficulty comes in.

It is conceivable that the increase in the paper currencies of Germany and other countries can be stopped. But it is quite another thing to ask that the quantity should be cut down, beyond the cutting down necessary to fund the amounts held by foreigners. On the other hand, the level of prices in these countries is intolerably high already, and they will become higher still if deflation proceeds in the areas from which supplies are to be drawn, unless deflation is resorted to. Here we come to the line where economics divides from politics. The economist can only point to the appropriate remedies; he cannot guarantee the political conditions which make the practical application of these remedies possible.

$\S 7$. It is not part of the object of the present book to discuss in detail the appropriate methods of deflation, assuming that deflation in itself desirable. But recent discussions of the technical problems of deflation have suggested the advisability of saying something on what has tended to become known as "devaluation." The proposals associated with this term are based on the fact that the paper currencies of Europe possess a very much smaller purchasing power than the gold money which they nominally represent used to possess, and further, that their intrinsic value is almost negligible. Let us suppose that the paper mark of to-day buys one-tenth as much as the old paper mark did. One method of deflation would be to cut down the currency until the residue possessed the same purchasing power as the former metallic money. Nine-tenths of the paper money would then have to disappear. Now suppose that instead of actually decreasing the amount of the paper money so far as quantity was concerned, the government enacted that each paper mark should 
pass current at one-tenth of its former nominal face value. This would be the same in effect as actually cutting down the quantity. For, if the quantity is cut down, the currency remaining will possess a higher purchasing power, owing to the diminution of quantity: the mark after devaluation would also possess a greater purchasing power. For there would be only one-tenth of the number of marks in existence after the second change, just as there would be only one-tenth of the former number in existence if the physical supply is cut down. The general principle which underlies this proposal is that the parity of token coins can be altered without difficulty.

The difficulty about this method of procedure seems to be that it is less easy of comprehension than the older and less visible process of cutting down the quantity. But in effect the two methods are the same. Of course it does not follow that deflation is desirable because a new method of deflation has been discovered. The objections to deflation are quite simple.* The fall of prices which results from it favours creditors at the expense of debtors. In particular it favours the creditor of the State at the expense of the taxpayer. For if the State borrows on a 5 per cent. basis when the mark is worth one-tenth of what it will be worth when the mark is deflated, then it is clear that the creditors will be repaid more than they lent, in terms of goods. So also the ultimate debtors, the taxpayers, will sacrifice a larger amount in the shape of taxation. For the money incomes of individuals will fall, whichever method of deflation is adopted, whilst the amount which the creditor of the State is to receive remains unaltered. It is fairly clear that this is one of the most serious of the difficulties connected with deflation: the others are the fall in the value of stocks when prices decline and the difficulty of adjusting wage rates to the new level of prices. Of these three problems possibly the

* These are the objections, but it does not follow that they are conclusive, or that the present writer holds that they are conclusive. 
most delicate is the wage problem. The desirability of deflation falls outside the scope of this book: but without deflation the exchanges cannot be reduced below their present level.

§8. Naturally a situation like the present one brings with it many suggestions for reform. We have only space to mention a few of them. The first is the idea of an international currency. Since the currencies of Europe are for the greater part in an hopeless condition, it is suggested that international trade should be conducted in terms not of the local currencies but of a new currency, guaranteed and supervised by the League of Nations. A variant of this idea is the scheme of Dr. Vissering of the Netherlands Bank. According to him, countries with depreciated currencies should have two currencies, one a gold currency, the other the present paper currency, which should circulate at varying rates to gold until such time as a reduction in its quantity should bring it to its nominal gold value again. It is often overlooked by those who clamour for an international currency that before the war there was an international currency, namely, gold. The fact that the standard coins of different countries varied in the amount of gold that they contained did not alter this fundamental fact in a world where coin and bar gold could move freely, and where the central banks of the monetary centres were always prepared to quote prices for the gold currencies. A gold coin like the Napoleon or the sovereign had an international currency in spite of the fact that it was legal tender in only a part of the world.

A new international currency could take the form of a standard gold coin, legal tender in all countries: this would be an improvement in the technique of currency affairs. Or it could take the form of a new paper currency, exchangeable into the currencies of other countries. The first solution would leave the present position exactly what it now is. If francs, 
marks, crowns are depreciated in terms of American dollars, they would be depreciated in terms of the new gold currency, which would in fact only be the old gold currencies reissued. The issue of a new paper currency would of course only help to raise prices still more in terms of gold, and it is extremely difficult to see where it would be issued or what purpose it could fulfil. The idea sometimes prevails that it could be used as a kind of international cheque to remit money from one country to another. But even assuming that it would be found useful in this respect, which I very much doubt, the value of this international cheque would vary from one country to another according to the relative degrees of inflation in these countries. Its value in terms of gold would depend on its convertibility into gold, and this implies that either the gold-using countries would have to agree to cash these notes freely, in which case they would of course insist on controlling the whole scheme: or the issuing authority would have to create its own gold reserve. How this is to be done is not explained. The whole idea is quite useless.

Dr. Vissering's scheme is rather different. There is no inherent difficulty in Austria creating a new gold currency and allowing its paper money to vary in terms of this new currency until the paper reached gold parity, when it would become convertible freely into gold. The drawback to the scheme simply is that it does nothing to alter the actual situation. The Austrian currency, so far as it was paper money, would vary in terms of this new gold coin just as it now does in terms of American gold dollars. It is true that in so far as Austrian exports are composed of materials which have first to be imported, the ease of calculation is increased by both groups of values being estimated in terms of the same unit, and that a stable one: but so long as wages and the other expenses of manufacture are estimated in terms of paper crowns, the foreign value of the goods will still be liable to fluctuations as the international value of the crown varies. 
§9. This brings one to the whole question of the granting of international gold credits as a means of re-establishing the exchanges of Europe. Desirable as it is that the superfluous goods of the rest of the world should be put at the disposal of the distressed countries in order that production may again begin, it is essential to recognise that as long as the problem of inflation is not dealt with, the exchanges will not be appreciably improved. That they will improve to some extent is certain. For the granting of such credits will decrease the stock of goods in the outside world for the time being, and increase them in Central Europe: thus the two price levels will come closer together and this will cause the value of the mark to rise. But this is a very different thing from saying that increased production will restore the pre-war parity. If the flood of paper money is not stopped, all that increased production can do is to prevent the rise of prices from proceeding quite as rapidly as before. But this increased production is itself only possible on the assumption that the articles produced can be sold at the world-price to yield a profit. In so far as they are made from materials produced at home, their value in terms of world currency will mean a higher return in the domestic currency for every fall in the exchange value of the local currency, but this will only mean increased profits so long as the local price level is such that the world price converted into the local currency leaves a margin over cost of production.* At the present time the under-valuation of the mark does probably leave an exceptionally wide margin of profit to the manufacturer : but to regard this state of affairs as an advantage to Germany is a grotesque reading of the situation. It means in effect that Germany is selling in terms of world goods at exceptionally unfavourable terms to herself, and every rise in the volume of paper money, which tends to increase the distrust which is felt in the future

- Once the rate of exchange is adjusted to a stable internal price level, it does not matter whether exchange is high or low. 
of the mark makes it still more difficult for Germany to buy world goods on reasonable terms.

$\S 10$. The argument that increased production will cause the exchanges to fall to parity can, as a matter of fact, be disproved without any reference to the theory of the exchanges. Let anyone look at the figures of inflation at the present moment and calculate the extent to which production must increase to restore the same relations between goods and money as existed before the war. Such an enormous increase in productivity would be required that the whole solution is hopeless from the beginning.

$\S 11$. If the fundamental condition for a restoration of the exchange system is a cessation of inflation, is there anything that can be done other than the stoppage of the printing presses? To this question the answer must be an unhesitating negative: but it does not follow that the stoppage of inflation cannot be supplemented by other devices. Of these devices, the most important is the establishment of the gold exchange standard. The object with which this scheme should be introduced is the minimisation of exchange fluctuations. As has already been argued, the fluctuations in existing rates are the inevitable result of the increase of the currency : but although the limits must be wider than they were before the war, it does not follow that no attempt to narrow these limits need be made.

We have already seen the essential ideas which underlie the gold exchange standard; let us here recall the really vital point. The system only functions when the internal and the external price levels are in equilibrium, and when the rates are adjusted to these price levels. It follows that it is quite impossible to maintain a stable rate if the process of inflation is not checked. For a constant rise in the internal price level will, if the rate of exchange is not adjusted thereto, very soon lead to the exhaustion of the world currency at the command of the regulatory 
authority. But this re-adjustment of rates of exchange is really only an expression of the depreciation of the local currency.

$\S 12$. Once the process of inflation is stopped, the process of establishing the gold exchange standard may require international credits. But the functioning of the system is not possible without such an initial rate of exchange as really expresses the relation between internal and external prices. The object of such an international loan should be to provide the necessary technical substratum : a fund which can be used to draw the first drafts for the payment of raw materials, and to provide for possible events, such as the failure of the local harvest, which may require a sudden and heavy import. But the normal flow into the fund must come from the sale of goods to foreign countries. This, as we have so often had to repeat, is not possible unless the prices are such as to make them capable of sale in competition with the goods of countries with a lower price level.

$\S 13$. But the gold exchange standard is utterly useless and even harmful if it is established before there is a reasonable hope of monetary stability. The danger is that the scheme will simply encourage purchases from abroad at rates of exchange which do not correspond to the purchasing power parity and therefore the fund will be exhausted.*

* In the Times for December 30,1920, will be found an article on the proposed new banknote for Austria, a scheme associated with the name of Sir Ernest Harvey. Part of the proposed objects of the new bank would be the establishment of a sterling exchange standard, the " new bank would undertake to provide, at an agreed rate, sterling in exchange for Austrian notes, or, conversely, Austrian notes in exchange for sterling." The exponents of this scheme do not seem to realise that the paper pound is not itself a stable instrument of exchange, and that, if an experiment of this sort is to be undertaken, it is much better to base the crown on gold at New York, than on paper in London. How difficult it is to get away from the balance of trade idea in business circles is seen from certain comments in the same article on the depression in the British Dominions overseas, in which it is stated that "If their exports of raw materials were normal, their exchangec would quickly return to parity." Considering that the South 
$\S 14$. Much of what has been said as to the uselessness of an international currency applies also to the scheme recently propounded to the Institute of Bankers (and previously to the Chambers of Commerce in Canada) by Mr. Darling, of the London Joint City and Midland Bank, for a fixed exchange between different parts of the Empire. It is no doubt desirable that there should be closer co-operation between the banking systems of the different portions of the Empire, but Mr. Darling goes very much further than this. His idea is that the Bank of England should become the bankers' bank for the whole of the Empire: that all the ultimate balances should be kept there : that if possible, a uniform currency should be instituted : and that the re-organised Bank of England should have the right to issue notes, based, not upon gold entirely, but upon approved bills of exchange.

The greater part of this scheme is unnecessary for the ends proposed. Fixed exchange between various parts of the Empire only requires a gold-exchange-standard

African pound is now worth less than the Bradbury, and that the South African Government does not propose to allow convertibility before June 30,1923 , it might have been reasonable for the writer of the article to ask how far the decline in the export trade of South Africa was due to the local rise of prices. Similarly, it might have been advisable to investigate more closely the relationship between inflation and the post-war collapse of Europe.

A writer on the monetary situation of the world at the present time can hardly escape the danger of regarding everything from the inflationary standpoint. Let me, therefore, hasten to add that even were the currency situation more normal than it is, Europe could not have avoided some of the distress from which it is now suffering. The idea that the whole world can turn the greater part of its resources, in men and goods, to the purposes of destruction without destroying its own well being, can only be entertained by those who are ignorant both of history and of the teachings of economic science. The lack of confidence and of hope in the future, induced by the Peace Treaties, the post-war expenditure on armaments by bankrupt and semi-bankrupt Governments, the post-war tiredness, are all features that in the aggregate weigh very heavily. But it is precisely these factors which have accentuated the temptation to increase the monetary supply, just as it is the desperate and disillusioned man who drinks, and, by drinking, completes his own ruin.

The currency policies of Australia and of South Africa form the subject-matter of two high!y interesting articles in the Economic Journal, December, 1920. 
scheme of the Indian type. The reason for the present breakdown, in so far as there is a breakdown, is simply due to local inflation. It may be true that centralised control will make it easier to institute supervision of the local currencies, although the normal gold-exchange system reveals inflation at least as easily. But quite apart from this, inter-Imperial exchange is not the only element to be considered. The Empire has relations with the outside world as well, and there is nothing in the scheme which will make this aspect of the situation any better than it is now. On the contrary, the proposal that bills should constitute the backing for a note issue seems to me to be a departure from the sounder rules under which the Bank of England has hitherto worked. The practical difficulties in this scheme are, however, so great that it is not likely to be adopted.

$\S 15$. We have come to the end of our task. The object of this little book was to examine the foreign exchanges before, during, and after the war. Its lesson can be very simply summed up: In two words it is : STOP INFLATION. But just as Mr. Chesterton, in a book very rightly called "What is Wrong with the World," began with a little girl's hair, which was cut off by order of a Medical Officer of Health, and therefrom deduced a revolution; so, by indicating inflation as the prime evil, we may go on to point out that much will have to be done in order that inflation may be stopped. A man may die a less romantic death in his bed than on the battlefield, but he dies nevertheless. It might be as well for us all if the statesmen of Europe were a little less concerned about the possibility of Europe drowning in a sea of blood, and contemplated more seriously the prospects of the suffocation of Europe in a flood of paper money. That would indeed be a less romantic, but not less certain, ending of Western Civilisation. 


\section{BIBLIOGRAPHY.}

Books upon foreign exchange may be divided in to two kinds : the technical manuals which deal with arbitraging of rates and the like manuals which deal with the theory and practice of the exchanges in a more or less elementary way. The letters $a, b, c$ prefixed to a work indicate that it is elementary, fairly advanced and very advanced. The prefix $t$ will be taken to indicate that the book is a technical manual useful only to those whose knowledge of the subject is considerable. All the prices are net.

A. Older books upon the subject.

(a) George Clare. "The A.B.C. of the Foreign Exchanges" (Macmillans, 4s.).

(b) George Clare. "Money Market Primer" (Effingham Wilson, 6s.).

(b) Viscount Goschen. "Foreign Exchanges" (EffinghamWilson, 6s.).

( ) Ottomar Haupt. "Parités et Arbitrages" (Effingham Wilson, out of print).

(b) Deutsch. "Arbitrage."

B. Modern Books on the Subject.

(a) Hartley Withers. "Money-Changing" (Murray, 6s.).

(a) John A. Todd. "The Mechanism of Exchange" (Milford, 7s. 6d.).

(a) Franklin Escher. "Primer of Foreign Exchange" (Macmillan Co., 5s.).

(b) Franklin Escher. "Foreign Exchange Explained" (Macmillan Co., 7s.)

(a) F. W. Spalding. "Primer of Foreign Exchange (Pitmans, 3s. 6d.).

(b) F. W. Spalding. "Foreign Exchange and Foreign Bills" (Pitmans, 6s.).

(c) F. W, Spalding. "Eastern Exchange, Currency and Finance" (Pitmans, 12s. 6d.).

(c) E. W. Kemmerer. "Modern Currency Reforms" (Macmillan Co., 13s.).

(c) J. M. Keynes. "Indian Currency and Finance" (Macmillans, 7s. 6d.)

(c) G. Findlay Shirras. "Indian Finance and Banking" (Macmillans, 18s.)

(c) Whitaker. "Foreign Exchange" (Appletons, 25s.) 
C. Articles bearing upon the Present Situation.

Gustav Cassel. " The Present Position of the Foreign Exchanges." Economic Journal, March and September, 1916.

Gustav Cassel. "Abnormal Deviations in International Fxchanges." Economic Journal, December, 1918.

Gustav Cassel. "The Depreciation of the German Mark." Economic Journal, December, 1919.

E. C. Van Dorp. "The Deviation of Exchanges." Economic Journal, December, 1919

E. C. Van Dorp. "Abnormal Deviations in International Exchanges." Economic Journal, September, 1920.

A. C. Pigou. "Some Problems of Foreign Exchange." Economic Journal, December, 1920.

J. F. Darling. "Stabilisation of Imperial Exchange." Journal of the Institute of Bankers, January, 1921.

D. Memoranda bearing upon the Present Position.

Proceedings of the Brussels International Financial Conference. (Published by Harrisons.)

Report of the Conference and Resolutions of the Committees, 2s. 6 d.

Report 3. Currency Statistics, 2s.

Repoit 11. Exchange Contiol, 3s.

Report 13 (3). Memorandum on the World's Monetary Problems by Prof. Gustav Cassel.

Report 13 (4). Memorandum on Credit Currency and Exchange Fluctuations by Prof A. C. Pigou.

(These last two, in one volume with other reports, 7s. 6d.) 
APPENDIX No. 1.

Resolution No. XV. of the Brussels International Conference.

"Attempts to limit fluctuations in exchange by imposing artificial control on exchange operations are futile and mischievous. In so far as they are effective they falsify the market, tend to remove natural correctives to such fluctuations and interfere with free dealings in forward exchange which are so necessary to enable traders to eliminate from their calculations a margin to cover risk of exchange, which would otherwise contribute to the rise in prices. Moreover, all Government interference with trade, including exchange, tends to impede that improvement of the economic conditions of a country by which alone a healthy and stable exchange can be secured." 


\section{ApPEndix No. 2. \\ Exchange Statistics. \\ Statistical Tables.}

The purport of the following tables will be obvious to anyone who takes the trouble to inspect them. The source from which the figures are taken is indicated in all cases in order to facilitate reference. It is necessary, however, to mention that the tables relating to the exchanges before the war as presented in this book represent the result of averaging the figures for the separate years, and that the author alone is responsible for the data as given. 
EXCHANGE TABLE 1.-AVERAGE RATE OF EXCHANGE* 1899-1908. LONDON ON

\begin{tabular}{|c|c|c|c|c|c|c|c|c|c|}
\hline & & $\begin{array}{l}\text { Paris, } \\
\text { Cheque. }\end{array}$ & $\begin{array}{l}\text { Berlin, } \\
\text { Short } \\
\text { Sight. }\end{array}$ & $\begin{array}{l}\text { New } \\
\text { York. }\end{array}$ & & & $\begin{array}{c}\text { Paris, } \\
\text { Cheque. }\end{array}$ & $\begin{array}{l}\text { Berlin, } \\
\text { Short } \\
\text { Sight. }\end{array}$ & $\begin{array}{l}\text { New } \\
\text { York. }\end{array}$ \\
\hline & week & 25. & $20.453 t$ & 4.86525 & $27 \mathrm{th}$ & week & 25.15075 & 20.4 & 4.871625 \\
\hline 2 & " & 25 & & 4 & & & 2 & & \\
\hline 3rd & t & 25 & 20.463 & 5 & 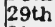 & & .15 & $20.441 \frac{1}{8}$ & 4.8718 \\
\hline 4th & $"$ & 25.162 & 20.472 & 25 & $30 \mathrm{th}$ & " & 25 . & $20.454 t$ & 4.8713 \\
\hline 5 th & , & 25 & 20 & 75 & & $n$ & 2 & 20.458 & 4.87125 \\
\hline 6 & , & 27 & 81 & 4 & nd & ", & 25.177 & $20.461 t$ & 4.872625 \\
\hline 7 & (1) & 25.1905 & 20.488 & 4.87 & 33rd & 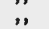 & 25.1905 & 20.459 & 4.872125 \\
\hline 8 & ; & 25 . & 20 & 4.8 & 34 th & "ו & 2 & 20 & 4.872 \\
\hline $9 \mathrm{t}$ & ; & 25. & 20 & 4.8 & 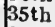 & ", & 05 & $20.453\}$ & 4.86725 \\
\hline $10 \mathrm{t}$ & , & 25 . & 20 & & & , & 2 & $46 t$ & 4.855125 \\
\hline 1t & , & 25 & 20 & 25 & & ", & 822 & & 625 \\
\hline $2 t$ & 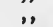 & & & & $38 \mathrm{th}$ & 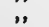 & 25.191 & 20 & 4.86225 \\
\hline $3 t$ & $"$ & 25 & 2 & & 30 & 13 & 25 . & & 125 \\
\hline $14 \mathrm{t}$ & . & 25 & 20 & 4.8 & 40 th & , & 25.1 & $20436 \frac{1}{2}$ & 4.86025 \\
\hline & 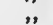 & 25 & 20 & 4 & & 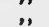 & & & 325 \\
\hline & ", & 25.16 & 204 & 4.872625 & $42 n d$ & , & 25.15075 & & 4.864 \\
\hline $7 t$ & , & 25.16 & 20.46 & 4.8 & $43 \mathrm{rd}$ & $"$ & 25.14425 & & 4.865625 \\
\hline of & ", & 25 & & 4.8 & & 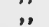 & & & 6125 \\
\hline t & 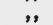 & 25.16 & 20.4 & 4.8 & 45 & 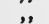 & 25. & 20.4 & 4.86475 \\
\hline & & 25.1 & 20.4 & 4.87 & & 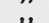 & & 20.4 & 4.8678 \\
\hline & ", & 25.16625 & 20.4 & 4.874625 & $47 \mathrm{th}$ & ", & 25.1765 & & 4.869125 \\
\hline & 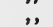 & 25.17 & 20.4 & 4.8 & 48 &, & 25.1782 & 20.4 & 88125 \\
\hline & ", & 25.1702 & 20.45 & 4.8 & 49 & $"$ & 25.17375 & & 4.865625 \\
\hline & 8 & 25.17225 & 20.4 & 4.8746 & 50 & $m$ & 25.1755 & 20.453 & 4.8625 \\
\hline & & 25.1697 & 20.4 & 4.87425 & &, & 95 & 20. & 4. \\
\hline & & 25.157 & 20.434 & 4.8720 & $52 \mathrm{nd}$ & & 25.1670 & $20.453 t$ & 4.86925 \\
\hline
\end{tabular}

- Based on the Statistical Volume presented to the National (U.S.A.) Monetary Commission: Statistics for Great Britain, Germany and France.

EXCHANGE TABLE II.-RATE OF EXCHANGE*, WEEKLY AVERAGE, 1909-13. I.ONDON ON

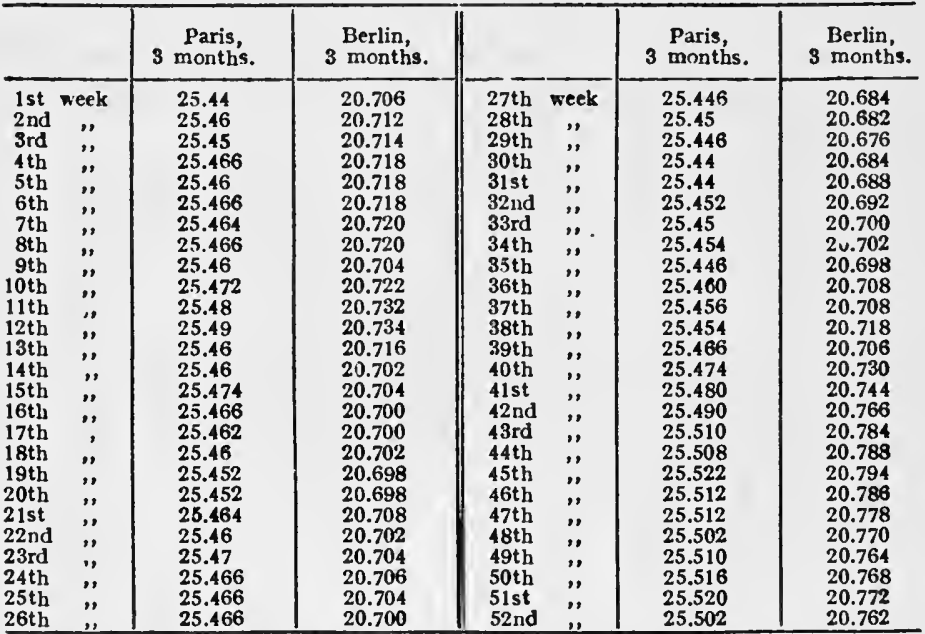

- Based on the tables in the Bankers' Almanac (London) for the years cited. 


\section{EXCHANGE TABLE III.}

"Spread" between the Highest and Lowest Daily Sight Rate, New York on London Averaged for the Period 1903-1919.*

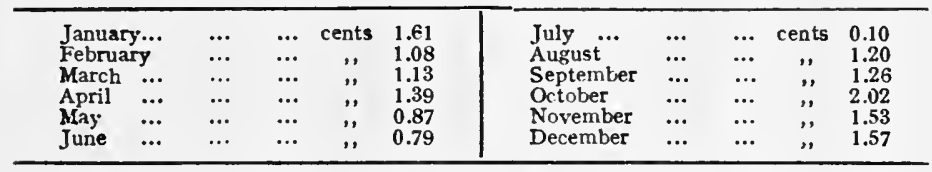

- Basea on tables presented to the National Monetary Commission of the U.S.A.

-EXCHANGE TABLE IV.-HIGHEST RATES FOR SIGHT DRAFTS IN NEW YORK DURING MONTH, EXPRESSED AS A PERCENTAGE OF PAR, 1914-1920.

[From Federal Reserve Bulletin, Sept., 1918, p. 837-8, and Nov., 1920, p. 1159.]

\begin{tabular}{|c|c|c|c|c|c|c|c|c|c|}
\hline & & $\begin{array}{l}\text { London } \\
\$ 4.8665 \\
=100\end{array}$ & $\begin{array}{l}\text { Paris } \\
\$ 19.3 \\
=100\end{array}$ & $\begin{array}{l}\text { Milan } \\
\$ 19.3 \\
=100\end{array}$ & $\begin{array}{c}\text { Yoko- } \\
\text { hama } \\
\$ 49.85 \\
=100\end{array}$ & $\begin{array}{l}\text { Rio cie } \\
\text { Janeiro } \\
\$ 32.444 \\
=100\end{array}$ & $\begin{array}{l}\text { Petro- } \\
\text { grad } \\
\$ 51.5 \\
=100\end{array}$ & $\begin{array}{l}\text { Berlin } \\
\$ 95.2 \\
=100\end{array}$ & $\begin{array}{l}\text { Vienna } \\
\$ 20.3 \\
=100\end{array}$ \\
\hline 1914 & & & & & & & & & \\
\hline June & ... & 100.50 & 100.62 & 100.36 & 100.10 & 一 & 100.12 & 100.25 & 100.10 \\
\hline July & $\ldots$ & 113.02 & 112.64 & 105.75 & 100.10 & - & 100.12 & 101.10 & 100.34 \\
\hline August & $\ldots$ & 114.25 & 101.61 & 105.75 & - & - & 99.26 & 101.89 & 100.34 \\
\hline September & $\ldots$ & 104.03 & 102.59 & 98.70 & - & - & - & 101.89 & - \\
\hline October & $\ldots$ & 102. & 102. & 100.21 & - & - & 93.20 & 99.00 & 97.8 \\
\hline November & $\ldots$ & 100.87 & 101 & 97.41 & - & - & 93.20 & 93.09 & 88.03 \\
\hline $\begin{array}{c}\text { December } \\
1915\end{array}$ & ... & 100.53 & 101 & 99 & - & -- & 83.50 & 97.16 & 88.67 \\
\hline January & & 99.7 & 100. & 97. & - & - & 84.47 & 92.83 & 86.21 \\
\hline Feb & .. & & 100. & 95. & - & - & 87.13 & 91 & 85.47 \\
\hline Marc & & 98. & 98. & 91.71 & - & - & 86.41 & 50 & 8 \\
\hline Apr & $\ldots$ & 98. & 97 & 89 & 99. & - & 86. & & 76.60 \\
\hline$y \ldots$ & & 98.6 & 97. & 90. & 99.06 & - & 81.07 & 87 & 77.34 \\
\hline June ... & $\because$ & 98.34 & & & & 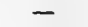 & & & \\
\hline July ... & . & 98.04 & 93.63 & 85.49 & 99.06 & - & 73.79 & 86.40 & 74.78 \\
\hline August & $\cdots$ & 97. & 91. & 83. & 99. & 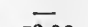 & 71 & & 74.88 \\
\hline September & $\ldots$ & 97.20 & 89.90 & 83.83 & 98.80 & & & & 76.60 \\
\hline October & 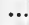 & 97.09 & 89. & 83.32 & 99.30 & 73.40 & 68.93 & 88.50 & 76.60 \\
\hline November & & 96. & 89. & 80 & 100 & & & & \\
\hline December & & 97.43 & 89.17 & 79.53 & 101.30 & 72.81 & 63.59 & 83.77 & 69.46 \\
\hline
\end{tabular}




\begin{tabular}{|c|c|c|c|c|c|c|c|c|c|}
\hline & & $\begin{array}{c}\begin{array}{c}\text { Tondon } \\
\$ 4.8665 \\
=106\end{array} \\
\end{array}$ & $\begin{array}{l}\text { Paris } \\
\$ 19.3 \\
=100 \\
\end{array}$ & $\begin{array}{l}\text { Milan } \\
\$ 19.3 \\
=100 \\
\end{array}$ & $\begin{array}{l}\text { Yoko- } \\
\text { hama } \\
\$ 49.85 \\
=100 \\
\end{array}$ & $\begin{array}{c}\text { Rio de } \\
\text { Janeiro } \\
\$ 32.444 \\
=100\end{array}$ & $\begin{array}{c}\text { Petro- } \\
\text { grad } \\
\$ 51.5 \\
=100 \\
\end{array}$ & $\begin{array}{l}\text { Berlin } \\
\$ 95.2 \\
=100\end{array}$ & $\begin{array}{l}\text { Vienna } \\
\$ 20.3 \\
=100\end{array}$ \\
\hline 1916 & & & & & 101.30 & 72.44 & 58.25 & & \\
\hline $\begin{array}{l}\text { January } \\
\text { February }\end{array}$ & $\cdots$ & $\begin{array}{l}98.22 \\
97.94\end{array}$ & $\begin{array}{l}88.86 \\
88.50\end{array}$ & $\begin{array}{l}79.12 \\
77.46\end{array}$ & $\begin{array}{l}101.30 \\
101.06\end{array}$ & $\begin{array}{l}72.44 \\
71.67\end{array}$ & $\begin{array}{l}58.25 \\
62.85\end{array}$ & $\begin{array}{l}80.62 \\
81.41\end{array}$ & $\begin{array}{l}63.65 \\
73.89\end{array}$ \\
\hline March & $\ldots$ & 97.91 & 88.19 & 79.69 & 100.80 & 72.81 & 63.11 & 77.07 & 64.04 \\
\hline April ... & $\ldots$ & 97.91 & 87.36 & 82.12 & 101.80 & 70.90 & 62.14 & 80.36 & 67.09 \\
\hline May ... & ... & 97.86 & 87.56 & 83.58 & 101.06 & 75.52 & 61.40 & 82.06 & 66.50 \\
\hline June ... & $\ldots$ & 97.79 & 87.82 & 81.61 & 101.30 & 75.52 & 59.81 & 81.01 & 65.27 \\
\hline July ... & $\ldots$ & 97.79 & 87.72 & 81.24 & 101.30 & 76.33 & 59.81 & 78.26 & 63.05 \\
\hline August & $\ldots$ & 97.79 & $\mathbf{5 7 . 9 8}$ & 80.16 & 101.56 & 75.99 & 66.02 & 76.02 & 61.58 \\
\hline September & $\ldots$ & 97.97 & 88.76 & 80.62 & 101.56 & 74.88 & 65. & 74.52 & 59.85 \\
\hline October & $\ldots$ & 97.75 & 88.76 & 80.16 & 102.31 & 74.29 & 61.65 & 74.12 & 59.11 \\
\hline November & $\ldots$ & 96.94 & 88.70 & 77.93 & 102.31 & 73.86 & 59.71 & 73.73 & 58.52 \\
\hline December & ... & 97.75 & 88.81 & 77.82 & 102.07 & 72.84 & 59.71 & 79.04 & 66.01 \\
\hline January & ... & 97.78 & 88.70 & 75.23 & 102.07 & 72.66 & 58.06 & 75.04 & 58.08 \\
\hline February & $\ldots$ & 97.77 & 88.65 & 73.16 & 102.31 & 72.32 & 56 & 74.44 & 54 \\
\hline March & $\ldots$ & 97.72 & 88.70 & 67.93 & 102.31 & 71.45 & 55. & 75.11 & 56.65 \\
\hline April & $\ldots$ & 97.78 & 91.24 & 75.18 & 102.58 & 75.05 & $56 . n 6$ & - & - \\
\hline May ... & $\ldots$ & 97.72 & 90.78 & 73.99 & 102.58 & 82.45 & 51 & - & - \\
\hline June ... & $\ldots$ & 97.72 & 90.52 & 73.63 & $102.8 !$ & 82.91 & 50.72 & - & - \\
\hline July ... & $\ldots$ & 97.74 & 90.41 & 72.18 & 102.81 & 82.67 & 46.44 & - & - \\
\hline August & $\ldots$ & 97.72 & 89.90 & 71.61 & 102.31 & 79.03 & 42.07 & 一 & 一 \\
\hline September & $\ldots$ & 97.72 & 89.79 & 68.86 & 103.06 & 77.73 & 34 & - & - \\
\hline October & $\ldots$ & 9 & 90.73 & 67. & 104 & 79. & 30 & - & - \\
\hline November & $\ldots$ & 97.65 & 90.36 & 65.23 & 104.57 & 80.91 & 26.23 & - & - \\
\hline $\begin{array}{c}\text { December } \\
1918\end{array}$ & $\ldots$ & 97.66 & 90.41 & 64.87 & 103.91 & 82.91 & 26.23 & - & - \\
\hline January & $\ldots$ & 97.68 & 90.83 & 62.33 & 103.91 & 83.65 & 25.51 & - & - \\
\hline February & $\ldots$ & & 90.73 & & 10 & 82. & 26 & - & -- \\
\hline March & $\ldots$ & 97.68 & 91.52 & 62.07 & 103.81 & 81.43 & 26.23 & 一 & 一 \\
\hline April ... & $\ldots$ & 97.71 & 96.62 & 58 & 104.11 & 79.64 & 28 & - & - \\
\hline May ... & $\ldots$ & 97.71 & 90.83 & 57.77 & 105.82 & 79.03 & 29.63 & - & - \\
\hline June ... & $\ldots$ & 97.71 & 90.6 & 58.50 & 106.12 & 79.03 & 29.63 & - & - \\
\hline July ... & $\ldots$ & 97.68 & 90.67 & 64.66 & 107.82 & 76.87 & 29.15 & - & - \\
\hline & & & & BREA & IN & RECOR & & & \\
\hline ctober & $\ldots$ & 97.71 & 94.77 & 81. & 109.59 & 77.05 & - & - & - \\
\hline November & ... & 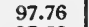 & 9 & & 109. & 83.22 & - & 一 & - \\
\hline $\begin{array}{c}\text { December } \\
1919\end{array}$ & 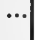 & 97.78 & 95.03 & 81.61 & 106.82 & 83.84 & - & - & - \\
\hline January & $\ldots$ & 97.78 & 94.97 & 81.40 & 104.81 & 82.45 & - & - & - \\
\hline Febiuary & $\cdots$ & 9 & 9. & & 103 & 80.45 & $\cdots$ & - & - \\
\hline March & $\ldots$ & & 94. & & 102 & 81. & - & - & - \\
\hline April ... & $\ldots$ & .01 & 8 & & 103 & 83.22 & - & - & 一 \\
\hline May ... & & 9 & 85.3 & 69. & 103 & 87.07 & - & - & - \\
\hline June ... & $\ldots$ & & 82.64 & & & 87. & - & - & - \\
\hline July ... & $\ldots$ & 9 & 79.7 & 6 & 102.81 & 86. & - & 33.59 & 17.27 \\
\hline August & ... & & & & & 83. & - & 30.44 & 14.80 \\
\hline September & $\ldots$ & & 66.2 & & 101 & 79. & - & 19.31 & 12.95 \\
\hline Octobe: & •. & & 6 & & & & - & 18.37 & 8.14 \\
\hline November & $\ldots$ & 85.53 & 58 & & 101 & 92. & - & 13.64 & 4.93 \\
\hline $\begin{array}{c}\text { December } \\
1920\end{array}$ & & 81.94 & 52.23 & 41. & 101 & 95.16 & - & 10.92 & 360 \\
\hline January & ... & 77.83 & 48.08 & 39.12 & 101 & 85. & - & 8.61 & 3.21 \\
\hline Febr & & & & & & & - & & 1.97 \\
\hline March & $\ldots$ & 81.22 & 39.1 & & 96.29 & 82. & - & 6.59 & 2.71 \\
\hline ril & ... & 82.5 & 35.9 & 25.44 & 99.80 & 83. & - & 8.19 & 2.71 \\
\hline May ... & $\ldots$ & 80.45 & 41.1 & & 104 & 81. & - & 12.34 & 3.75 \\
\hline June ... & $\ldots$ & 81.9 & 43.4 & 32.18 & 102 & 80. & - & 11.54 & 3.94 \\
\hline $\mathrm{Ju}$ & & 81.1 & 44.2 & 31.87 & 103 & 73. & - & 11.13 & 3.55 \\
\hline 1st & $\cdots$ & 76.18 & 39.4 & 27.41 & 103.31 & 67. & - & 9.61 & 3.01 \\
\hline September & $\ldots$ & 73.20 & 36.32 & 24.30 & 103.31 & 60.49 & - & 8.52 & 2.31 \\
\hline October & $\ldots$ & 72.07 & 34.97 & 21.66 & 102.81 & 56.64 & - & 6.93 & 2.17 \\
\hline
\end{tabular}


EXCHANGE TABLE V.-ACTUAL RATES OF EXCHANGE ON SWITZERLAND, 1914-18. AVERAGE OF BUYING AND SELLING PRICES.

[From Revue Commerciale et Industrielle Suisse, 1914.18, p. 146.]

\begin{tabular}{|c|c|c|c|c|c|c|c|c|}
\hline Month. & & 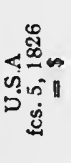 & 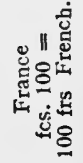 & 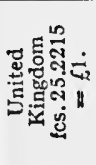 & 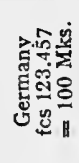 & 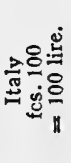 & 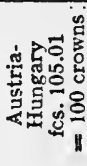 & 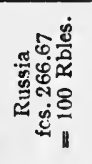 \\
\hline $\begin{array}{c}1914 \\
\text { January }\end{array}$ & & & & & & & & \\
\hline $\begin{array}{l}\text { January } \\
\text { February }\end{array}$ & … & - & 100.12 & 25.18 & 123.17 & 99.70 & 105.03 & $\begin{array}{c}263.79 \\
-\end{array}$ \\
\hline March ... & $\ldots$ & 5.17 & 100.05 & 25.18 & 123.17 & 99.65 & 104.83 & 265.22 \\
\hline April ... & $\cdots$ & - & - & - & - & -- & - & - \\
\hline May $\ldots$ & $\cdots$ & 5 & & $9=$ & & 08 & & \\
\hline & $\ldots$ & $\begin{array}{l}5.15 \\
5.14\end{array}$ & $\begin{array}{l}100.10 \\
100.03\end{array}$ & $\begin{array}{l}25.19 \\
25.10\end{array}$ & 122.87 & $\begin{array}{l}99.86 \\
99.45\end{array}$ & $\begin{array}{l}104.28 \\
103.92\end{array}$ & $\begin{array}{l}261.48 \\
250.59\end{array}$ \\
\hline $\begin{array}{l}\text { July (27) } \\
\text { August... }\end{array}$ & $\begin{array}{l}\cdots \\
\cdots\end{array}$ & & 100.00 & $\begin{array}{l}25.10 \\
25.10\end{array}$ & $\begin{array}{l}122.67 \\
121.09\end{array}$ & $\begin{array}{l}99.45 \\
98.50\end{array}$ & $\begin{array}{r}103.92 \\
92.00\end{array}$ & nominal \\
\hline September & $\ldots$ & 5.07 & 100.50 & 25.25 & 116.00 & 95.00 & 91.00 & 206.93 \\
\hline October & $\ldots$ & 5.17 & 100.75 & 25.36 & 115.12 & 97.85 & 92.50 & 219.05 \\
\hline November & $\ldots$ & 5.20 & 102.00 & 25.49 & 111.25 & 97.75 & 89.00 & 217.00 \\
\hline $\begin{array}{c}\text { December } \\
1915\end{array}$ & $\ldots$ & 5.23 & 101.65 & 25.47 & 114.50 & 98.65 & 91.00 & 217.50 \\
\hline January & $\ldots$ & 5.29 & 102.15 & 25.65 & 115.22 & 97.55 & 90.00 & 222.50 \\
\hline February & $\ldots$ & 5.49 & 104.25 & 26.36 & 111 & 93.50 & 84.00 & 225.00 \\
\hline March & $\ldots$ & 5.37 & 101.40 & 25.80 & 110.22 & 92.56 & 82.00 & 228.00 \\
\hline April ... & $\ldots$ & 5.31 & 100.11 & 25.52 & 108.80 & 91.12 & 81.50 & 225.00 \\
\hline May ... & $\ldots$ & 5.29 & 97.55 & 25.33 & 108.25 & 90.00 & 80.25 & 210.00 \\
\hline June ... & $\ldots$ & 5.39 & 96.85 & 25.90 & 169.40 & 88.87 & 81.00 & 210.00 \\
\hline Jisly $\ldots$ & $\ldots$ & 5.37 & 95.00 & 25.63 & 109.00 & 85.00 & 80.50 & 190.00 \\
\hline August... & $\ldots$ & 5.41 & 90.80 & 25.11 & 108 & 83.50 & 80.35 & 190.00 \\
\hline September & $\ldots$ & 5.3 & 91.75 & 24.97 & 109.55 & 84.75 & 78.75 & 190.00 \\
\hline October & $\ldots$ & 5.3 & 90.15 & 24 & $10 \mathrm{~s}$ & 83.25 & 77.40 & 190.00 \\
\hline November & $\ldots$ & 5.37 & 91.50 & 25.26 & 105.85 & 82.45 & 74.37 & 175.00 \\
\hline $\begin{array}{c}\text { December } \\
1916\end{array}$ & $\ldots$ & 5.25 & 89.65 & 24.91 & 98.75 & 79.50 & 67.00 & 160.00 \\
\hline $\begin{array}{l}1910 \\
\text { January }\end{array}$ & $\ldots$ & 5.20 & 88.85 & 24.80 & 95.37 & 76.75 & 63.85 & 155.00 \\
\hline February & $\ldots$ & 5.2 & 89 & 25 & 94 & & 65.00 & 160 \\
\hline March ... & $\ldots$ & 5.22 & 87.35 & 24.86 & 92.80 & 79.12 & 64.10 & 164.50 \\
\hline April ... & $\ldots$ & 5.19 & 87.65 & 24.77 & 95 & 82.00 & 66 & 161.50 \\
\hline May $\ldots$ & $\cdots$ & 5.24 & 88.85 & 24.99 & 97. & 82.80 & 67.60 & 160.50 \\
\hline June $\quad .$. & $\ldots$ & 5.29 & 89.65 & 25.22 & 95.65 & 82.95 & 66.50 & 162.50 \\
\hline July $\ldots$ & $\ldots$ & 5.30 & 89.75 & 25.24 & & 81.70 & 65.65 & 162.00 \\
\hline August... & $\ldots$ & 5.31 & 90.07 & 25.27 & 92.50 & 81.75 & 63.75 & 173.50 \\
\hline September & $\ldots$ & 5. & 91. & 6 & & & & 171.00 \\
\hline October & $\ldots$ & 5.26 & 90.05 & 25.01 & 90 & 79.20 & 59.35 & 161.00 \\
\hline November & $\cdots$ & 5.16 & 88. & 24.60 & 84 & & 5 & 153.00 \\
\hline December & $\ldots$ & 5.07 & 86.75 & 24.11 & 84.60 & 73.90 & 53.37 & 151.50 \\
\hline $\begin{array}{c}1917 \\
\text { January }\end{array}$ & $\ldots$ & 5.03 & 86.10 & 23.93 & 84.60 & 69.80 & 54.40 & 141.25 \\
\hline February & & 5. & & & & & & \\
\hline March & $\cdots$ & 5. & 86. & 23.98 & 79. & 65 & 50.10 & 143.00 \\
\hline April ... & $\ldots$ & 5.16 & 90. & 24.57 & 79.25 & 73.25 & 49.60 & 146.00 \\
\hline May $\ldots$ & ... & 5.03 & 88. & 23.98 & 75.10 & 71.60 & 48.40 & 135.00 \\
\hline & $\ldots$ & 4.83 & 84.20 & 23 & & 67.00 & 43.50 & 110.00 \\
\hline July $\quad \ldots$ & $\ldots$ & 4.58 & 79.00 & 21.65 & 63. & 62.90 & 40 & 99.00 \\
\hline August... & $\ldots$ & 4.59 & 79. & 21 & 63 & 61 & 40.80 & 93.50 \\
\hline September & $\ldots$ & 4.7 & 81.20 & 22.35 & 64 & 60.65 & 41.50 & 78.00 \\
\hline October & $\ldots$ & 4.53 & 78.80 & 21.50 & 63. & 56 & & 65.00 \\
\hline November & $\ldots$ & 4. & 75.80 & 20.67 & 65.00 & 51.00 & 40.25 & 55.00 \\
\hline December & . & 4.37 & 76.70 & 20.87 & 85.75 & 52.50 & 52.50 & 70.00 \\
\hline
\end{tabular}




\begin{tabular}{|c|c|c|c|c|c|c|c|c|}
\hline Month. & & 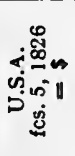 & 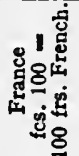 & 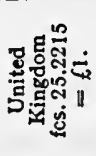 & 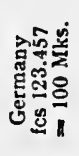 & 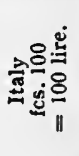 & 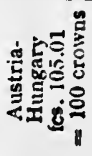 & 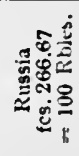 \\
\hline $\begin{array}{l}1918 \\
\text { January } \\
\text { February } \\
\text { March ... } \\
\text { April ... } \\
\text { Alay . ... } \\
\text { June ... } \\
\text { July _.. } \\
\text { August... } \\
\text { September } \\
\text { October } \\
\text { November } \\
\text { December }\end{array}$ & $\begin{array}{l}\ldots . \\
\ldots . \\
\ldots . \\
\ldots \\
\ldots \\
\ldots\end{array}$ & $\begin{array}{l}4.49 \\
4.45 \\
4.30 \\
4.20 \\
4.03 \\
3.94 \\
3.94 \\
4.30 \\
4.60 \\
4.97 \\
4.95 \\
4.82\end{array}$ & $\begin{array}{l}79.00 \\
78.00 \\
75.30 \\
73.90 \\
70.40 \\
69.80 \\
69.20 \\
78.75 \\
84.00 \\
91.00 \\
90.60 \\
88.50\end{array}$ & $\begin{array}{l}21.48 \\
21.20 \\
20.47 \\
20.01 \\
19.15 \\
18.95 \\
18.80 \\
20.50 \\
22.00 \\
23.70 \\
28.55 \\
22.98\end{array}$ & $\begin{array}{l}82.75 \\
86.75 \\
85.10 \\
82.10 \\
79.10 \\
69.00 \\
65.80 \\
68.40 \\
67.50 \\
72.00 \\
62.75 \\
60.00\end{array}$ & $\begin{array}{l}52.70 \\
50.80 \\
49.10 \\
46.75 \\
44.00 \\
43.50 \\
44.25 \\
61.00 \\
71.00 \\
77.50 \\
76.75 \\
74.40\end{array}$ & $\begin{array}{l}52.50 \\
57.50 \\
55.25 \\
52.60 \\
48.75 \\
40.00 \\
39.50 \\
38.00 \\
37.75 \\
42.00 \\
32.75 \\
30.50\end{array}$ & $\begin{array}{l}77.00 \\
75.00 \\
75.00 \\
70.00 \\
65.00 \\
60.00 \\
55.00 \\
60.00 \\
55.00 \\
90.00 \\
80.00 \\
70.00\end{array}$ \\
\hline
\end{tabular}

CURRENCY STATISTICS.

†TABLE I.-PERCENTAGE CHANGES IN PRICES AND NOTE ISSUES SINCE 1913. $(1913=100$.

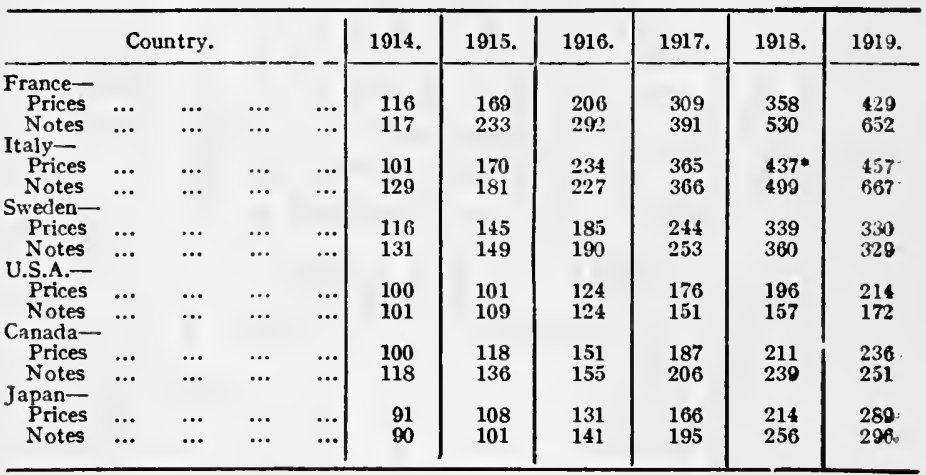

- November, 1918, expressed as percentage of December, 1917.

+ Table C., p. 99, Paper No. III., Brussels International Financial Conference. 


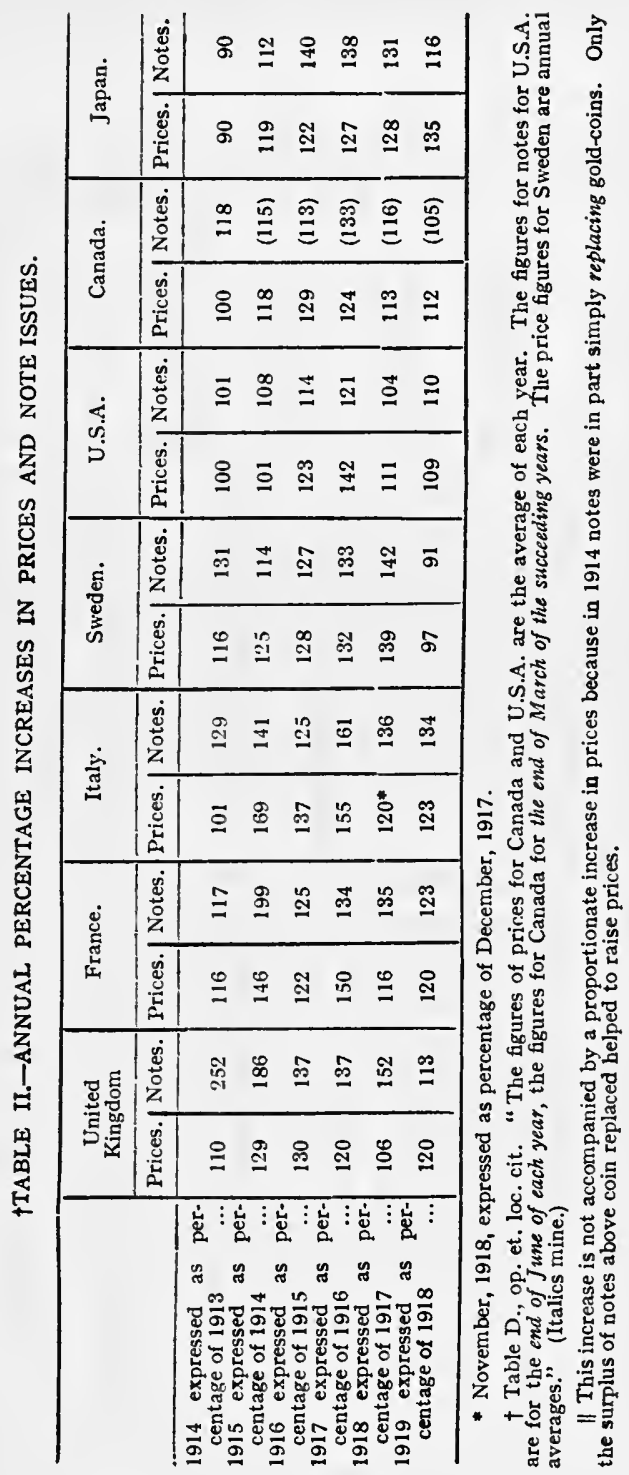




\section{NO'TES IN CIRCULATION.}

ICURRENCY TABLE III,-IN MILL $€$ s, CONVERTED AT APPROXIMATELY PAR RATES.

\begin{tabular}{|c|c|c|c|c|c|c|c|c|}
\hline & & & End & of Docen & aber in & & & \\
\hline Country & 1913 & 1814 & 1915 & 1916 & 1917 & 1918 & 1818 & 1920 \\
\hline $\begin{array}{l}\text { U. K. Currency } \\
\text { Notes }\end{array}$ & 28.6 & 38.5 & $103.1 t$ & 150.2 & 212.8 & 323.2 & 356.2 & 367.6 \\
\hline U.K. Bank & & & & & & & & - \\
\hline $\begin{array}{l}\text { Notes } \\
\text { U.S.A. Federal }\end{array}$ & - & 36.2 & 35.3 & 39.7 & 46.6 & $70 \cdot 2$ & $87 \cdot 47$ & $113.4 \ddagger$ \\
\hline Res. Notes & - & - & $16.7^{*}$ & $36.1 *$ & $113.4^{*}$ & $356.9 *$ & $519.6^{*}$ & 745.6 \\
\hline Paper & $526.8^{*}$ & $533.4 *$ & $557.3^{*}$ & $620.0^{*}$ & $679.8^{*}$ & $470.4^{*}$ & $387.6^{*}$ & 375.9 (Nov ${ }^{2} 20$ ) \\
\hline France & 228.5 & 267.3 & 532.4 & 667.2 & 893.5 & 1210.0 & 1491.0 & 1500 . \\
\hline Notes & 20.0 & 26.3 & 43.3 & 52.7 & 79.0 & 85.0 & 90.8 & 90.8 (August) \\
\hline $\begin{array}{l}\text { Italy, Bank } \\
\text { Notes }\end{array}$ & 81.3 & 117. & 158.7 & 200.5 & 337.0 & 470.0 & 651.3 & $779.17(\mathrm{~N}$ \\
\hline Jараг & 42.6 & 38.6 & 43.0 & 60.1 & 83.1 & 108.1 & 126.0 & 104 \\
\hline Denmark & 8.4 & 11.5 & 12.2 & 15.8 & 18.8 & 25.0 & 27.2 & 30.6 \\
\hline Holland & 26.1 & 39.4 & 46.5 & 63.2 & 74.2 & 89.1 & 86.1 & 88.5 \\
\hline Spa & 77.0 & 78.6 & 84.1 & 84.4 & 111.3 & 132.6 & 154.3 & 171 \\
\hline Switzerland & 12.6 & 18.3 & 18.6 & 21.5 & 28.1 & 39.1 & 41.5 & 40.5 \\
\hline & 12.2 & 16.0 & 18.2 & 23.2 & 30.9 & 43 & 40.1 & 40 \\
\hline $\begin{array}{l}\text { Norway } \\
\text { Germany }\end{array}$ & 5.9 & 7.4 & 8.9 & 13.9 & 18.0 & 24.0 & 25.0 & 27.1 \\
\hline Germ & & & & & & & & \\
\hline Notes & 129.7 & 252.3 & 345.9 & 402.8 & 573.4 & 1109.4 & 1784.9 & 3382.9 \\
\hline $\begin{array}{c}\text { Germany : } \\
\text { Loan }\end{array}$ & & & & & & & & \\
\hline Bureau Notes & - & 21.8 & 47.3 & 141.0 & 307.6 & 497.0 & 673.2 & 5 (Nov'20) \\
\hline Austria & 103.9 & $87.8 t$ & & & & & 2270.0 & 3209.3 \\
\hline Poland & - & - & - & - & - & - & $61.2 \S$ & $534.5 \S$ \\
\hline Belgium & 42.7 & $38.1+$ & -5 & & - & 7 & 190.6 & 242.3 \\
\hline $\begin{array}{l}\text { Canada } \\
\text { Australia }\end{array}$ & $\begin{array}{l}21.7 \\
10.0\end{array}$ & $\begin{array}{l}20.4^{*} \\
19.8\end{array}$ & $\begin{array}{l}20.5^{*} \\
41.8\end{array}$ & $\begin{array}{l}25.4^{*} \\
46.7\end{array}$ & $\begin{array}{l}32.2 \\
47.9\end{array}$ & $\begin{array}{l}40.2^{*} \\
59.1\end{array}$ & $\begin{array}{l}44.7 \\
56.6\end{array}$ & $\begin{array}{l}48.2 \text { (Nov } 20) \\
54.9 \text { (Nov } 20)\end{array}$ \\
\hline
\end{tabular}

- End of June in the years stated.

+ Mid-June.

Excluding Bank of England Notes in Currency Reserve.

Thank of Italy only.

II From Monthly Bulletin of Statistics and Economist.

\$ March 31 in each year.

(December 31,1020 , returned as $\mathbf{4 9 . 4}$ milliards Polish marks.) 
CURRENCY TABLE No. IV.

(From the "Times" City page, December 21, 1920).

\section{BRITAIN'S EXTERNAL DEBT.}

\section{Payments Maturing in Next Five Years.}

In a written answer to a question in Parliament by Lieutenant Colonel Walter Guinness, who asked what amounts of debt fall due for payment to Great Britain from various foreign countries and from Great Britain to various foreign countries in each of the next five years, the Chancellor of the Exchequer stated :-

The following sums mature for payment abroad by His Majesty's Government during the next five years. Payment is due to the public of these countries unless specifically shown as due to a foreign Government :-

\begin{tabular}{|c|c|c|}
\hline- & - & $\begin{array}{l}\text { Sterling at par or } \\
\text { as collateral held. }\end{array}$ \\
\hline 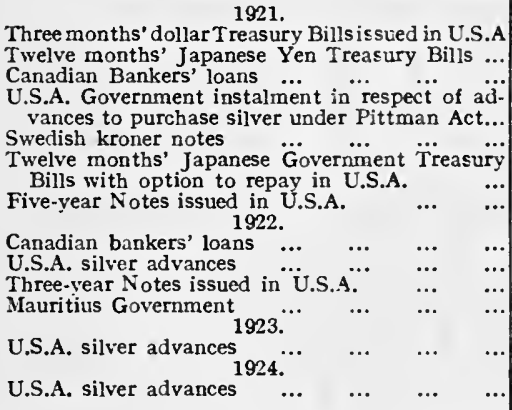 & $\begin{array}{r}\$ 20,850,000 \\
\text { Yens0,000,000 } \\
\$ 100,000,000 \\
\$ 30,500,000 \\
\text { Kr.12,500,000 } \\
\$ 28,590,000 \\
\$ 129,046,000 \\
\$ \$ 0,000,000 \\
\$ 30,500,000 \\
\$ 95,107,200 \\
\text { Rs.8,071,300 } \\
\$ 30,500,000 \\
\$ 30,500,000 \\
\$ 30,500,000\end{array}$ & $\begin{array}{r}4,760,000 \\
5,121,000 \\
21,228,000 \\
6,268,000 \\
826,000 \\
6,000,000 \\
26,516,000 \\
8,220,000 \\
6,268,000 \\
19,542,000 \\
538,000 \\
6,268,000 \\
6,268,000 \\
6,268,000\end{array}$ \\
\hline
\end{tabular}

In addition the loan from the Argentine Government will be reduced in 1921 by the equivalent of United States $\$ 50,000,000$ advanced to the Argentine Government, to be repaid by them and set against the loan to H.M. Government. The balance, which will then be approximately $30,000,000$ Argentine gold pesos, will thereafter be repaid over a period of about three years.

No definite arrangements have been made as to the date of repayment of the balance of debts due by H.M. Government to foreign Governments, or of debts due to H.M. Government by foreign Governments, which are at present short term in form. 

$8108 ?$ 


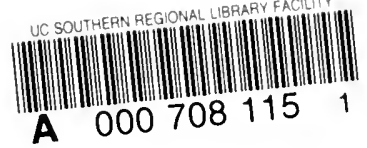


